AN ECOLOGICAL ASSESSMENT OF INVASIVE PLANT SPECIES IN A CONSTRUCTED STORMWATER WETLAND IN MARKHAM, ONTARIO, CANADA

by

Antonia Capotorto

BSc, York University, 2006

\author{
A thesis \\ presented to Ryerson University \\ in partial fulfillment of the \\ requirements for the degree of \\ Master of Applied Science \\ in the Program of \\ Environmental Applied Science and Management
}

Toronto, Ontario, Canada, 2008

(C) Antonia Capotorto 2008 


\title{
AN ECOLOGICAL ASSESSMENT OF INVASIVE PLANT SPECIES IN A CONSTRUCTED STORMWATER WETLAND IN MARKHAM, ONTARIO, CANADA
}

(C) Antonia Capotorto, 2008

Master of Applied Science

Environmental Applied Science and Management

Ryerson University, Toronto, Ontario, Canada

\begin{abstract}
It is generally assumed that increased plant biodiversity will enhance the efficiency and effectiveness of the pollutant removal processes in wetlands constructed for stormwater management and will provide ancillary benefits for wildlife and the general public. However, the development of a diverse plant community may be jeopardized by colonization by invasive species. This study reports on a detailed assessment of the changes in plant species composition in a wetland complex constructed for stormwater management in Markham, Ontario, Canada. The research presented focuses on the relationship between the presence of invasive species, the lack of development of native species diversity, and the environmental factors that may be associated with the presence and distribution of invasive plants. Today, vegetation diversity of the wetland remains extremely poor and there has been significant establishment of invasive species, especially Typha angustifolia. Despite the complexity of the site, there are few environmental determinants for plant growth.
\end{abstract}




\section{Acknowledgements}

First, I would like to thank my thesis supervisor, Dr. Michal Bardecki, for his patience while I struggled to find the ideal thesis topic and for supporting my research. Your insight, expertise, advice, and guidance were fundamental to the successful completion of my thesis.

Furthermore, this thesis would not be possible without access to the facility under study, laboratories for data analysis, and any background literature related to the site. For that, I would like to thank Karen Boniface of the Town of Markham, Miriam de Jong of Ryerson University, Nick Schrier of the University of Guelph's Soil and Nutrient Laboratory, and Tim Van Seters of the Toronto \& Region Conservation Authority.

Last but not least, I would like to express my deepest gratitude to my family and friends for all their love, support, and encouragement throughout my academic endeavors. In particular, I am forever indebted to my parents Domenic and Nancy Capotorto, and my brother Peter Capotorto, who assisted me with data collection and allowed me to turn our home into a temporary laboratory housing my vegetation, soil, and water samples. To Anthony Testa, your help with data collection was also invaluable. Thank you for being my foundation, not only during this process, but in all other aspects of my life. Finally, I must express special thanks to Anoushka Martil. I am so grateful for our friendship and I can say with certainly that I would have never survived these last few years without you. 
Author's Declaration

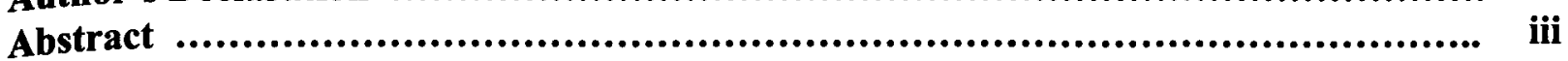

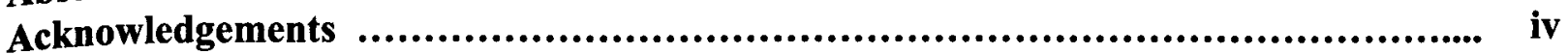

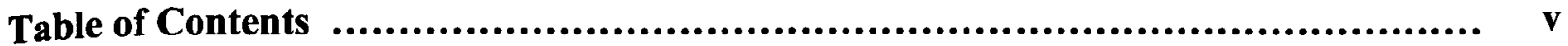

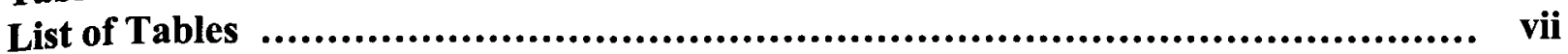

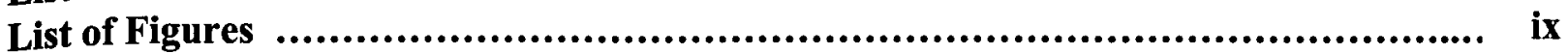

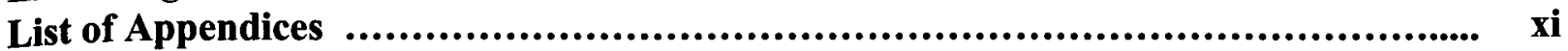

\section{Chapter 1: Introduction, Background, and Research Objectives}

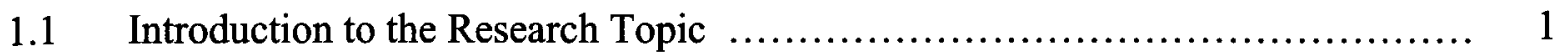

1.2 Wetlands: Functions, Values, and Vegetation Characteristics $\ldots \ldots \ldots \ldots \ldots \ldots \ldots .2$

1.3 Constructed Wetlands ...................................................... 4

1.3.1 Various Designs for Constructed Stormwater Wetland ............... 6

1.3.2 The Role of Vegetation in Constructed Stormwater Wetlands .......... 9

$1.4 \quad$ Invasive Plant Species in Wetland Communities .............................. 10

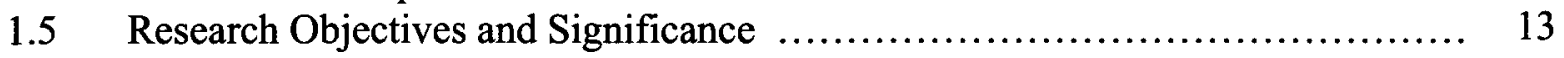

\section{Chapter 2: Methodology}

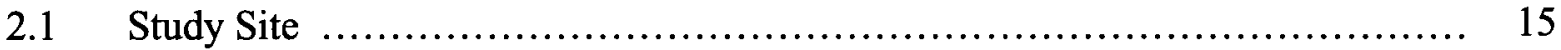

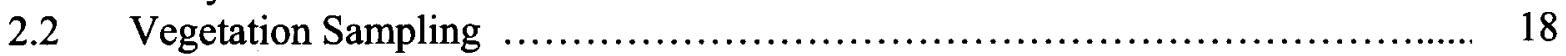

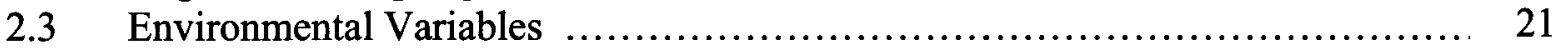

2.3.1 Soil Sampling ..................................................... 21

2.3.2 Water Sampling ............................................. 21

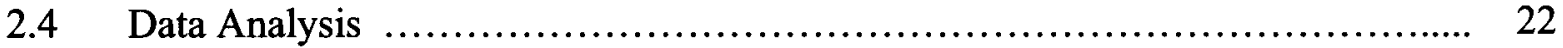

\section{Chapter 3: Results}

3.1 Assessment of Individual Species in the Wetland Complex .................... 25

3.1.1 Species Composition within the Wetland Complex .................. 25

3.1.2 Species Abundance within the Wetland Complex .................... 29

3.2 Assessment of Invasive and Native Species in the Wetland Complex ........... 31

3.2.1 Invasive and Native Species Composition and Abundance within the Wetland Complex .............................................. 31

3.2.2 Relationship between Invasive and Native Species within the Wetland Complex ........................................................... 36

3.3 Environmental Relationships within the Wetland Complex .................. 36

3.3.1 Potential Trends in Soil Chemistry Variables between Wetland Cells of the Markham BMP ....................................... 38

3.3.2 Potential Influences of Soil Chemistry Variables on Community Composition 
3.3.2.1 Relationships between Soil Chemistry Variables and Individual Plant Species within the Wetland Complex

3.3.2.2 Relationships between Soil Chemistry Variables and Invasive and Native Plant Species within the Wetland Complex

3.3.3 Potential Trends in Water Chemistry Variables Between Subsystems of Markham BMP

3.3.4 Potential Associations between Water Chemistry Variables and Community Composition

3.3.4.1 Relationships between Water Chemistry Variables and Individual Plant Species within the Wetland Complex

3.3.4.2 Relationships between Water Chemistry Variables and Invasive and Native Plant Species within the Wetland Complex

3.4 Summary of Key Results

\section{Chapter 4: Discussion and Conclusions}

4.1 Transformation in Species Composition and Abundance from Previous Assessments of Vegetation at the Markham BMP

4.1.1 Effects of Urbanization

4.1.2 Presence of Scirpus tabernaemontani

4.2 Interaction between Invasive and Native Plant Species at the Markham BMP ....

4.2.1 Competitive Relationship between Typha angustifolia and Typha latifolia

4.2.2 Potential for Typha angustifolia and Typha latifolia hybridization 71

4.2.3 Possible Phalaris arundinacea Suppression by Typha spp. 74

Relationship between Plant Species and Environmental Conditions at the

4.3 Relationship betwe
Markham BMP

4.3.1 Association between Plant Species and Soil Chemistry Variables 79

4.3.2 Association between Plant Species and Water Chemistry Variables ....

4.3.3 Unexpected Observations between Environmental Variables and Plant Species Abundance within the Wetland Complex

4.3.4 Comparison of Water Chemistry Measurements with Previous Assessments of Water Quality at the Markham BMP

4.4 Management Recommendations for Constructed Stormwater Wetlands ......... 92

4.4.1 Site Availability ................................................. 94

4.4.2 Species Availability and Species Performance ....................... 96

4.5 Summary of Important Conclusions 


\section{List of Tables}

Table 1: Mean $\pm 1 \mathrm{SE}$ values for soil chemistry variables observed in soil samples collected in each of the four wetland cells at the Markham BMP site in July 2007

Table 2: Correlation coefficient (r) values for relationships between Typha angustifolia, Phalaris arundinacea, and Typha latifolia stem density and soil characteristics such as $\mathrm{NH}_{4}-\mathrm{N}, \mathrm{NO}_{3}-\mathrm{N}$, soil organic matter, and soil $\mathrm{pH}$

Table 3: Correlation coefficient (r) values for relationships between Typha angustifolia, Phalaris arundinacea, and Typha latifolia stem density and soil characteristics such as plant available $\mathrm{P}, \mathrm{K}$, and $\mathrm{Mg}$

Table 4: Correlation coefficient (r) values for relationships between Typha angustifolia, Phalaris arundinacea, and Typha latifolia biomass and soil characteristics such as $\mathrm{NH}_{4}-\mathrm{N}, \mathrm{NO}_{3}-\mathrm{N}$, soil organic matter, and soil $\mathrm{pH}$

Table 5: Correlation coefficient (r) values for relationships between Typha angustifolia, Phalaris arundinacea, and Typha latifolia biomass and soil characteristics such as plant available $\mathrm{P}, \mathrm{K}$, and $\mathrm{Mg}$

Table 6: Correlation coefficient (r) values for relationships between invasive and native species stem density and soil characteristics such as $\mathrm{NH}_{4}-\mathrm{N}, \mathrm{NO}_{3}-\mathrm{N}$, soil organic matter, and soil $\mathrm{pH}$

Table 7: Correlation coefficient ( $\mathrm{r}$ ) values for relationships between invasive and native species stem density and soil characteristics such as plant available $P, K$, and $\mathrm{Mg}$

Table 8: Correlation coefficient (r) values for relationships between invasive and native species biomass and soil characteristics such as $\mathrm{NH}_{4}-\mathrm{N}, \mathrm{NO}_{3}-\mathrm{N}$, soil organic matter, and soil $\mathrm{pH}$

Table 9: Correlation coefficient ( $\mathrm{r}$ ) values for relationships between invasive and native species biomass and soil characteristics such as plant available $P, K$, and $\mathrm{Mg}$

Table 10: Mean \pm 1 SE values for water chemistry variables observed in water samples collected in each subsystem at the Markham BMP site in July 2007

Table 11: Correlation coefficient (r) values for relationships between Typha angustifolia and Typha latifolia stem density and water chemistry characteristics such as TKN, water $\mathrm{pH}, \mathrm{DO} \%$ saturated, TDS, and salinity 
Table 12: Correlation coefficient (r) values for relationships between Typha angustifolia and Typha latifolia biomass and water chemistry characteristics such as TKN, water $\mathrm{pH}, \mathrm{DO} \%$ saturated, TDS, and salinity

Table 13: Correlation coefficient ( $\mathrm{r}$ ) values for relationships between invasive and native species stem density and water chemistry characteristics such as $\mathrm{TKN}$, water $\mathrm{pH}$, DO \% saturated, TDS, and salinity

Table 14: Correlation coefficient (r) values for relationships between invasive and native species biomass and water chemistry characteristics such as $\mathrm{TKN}$, water $\mathrm{pH}$, DO \% saturated, TDS, and salinity

Table 15: A comparison between water chemistry measurements observed during various assessments of the Markham BMP site and regulatory limits and guidelines

Table 16: July 2007 water chemistry measurements observed in water samples collected in the Markham BMP during wet weather and dry weather events

Table 17: SWAMP water chemistry measurements from 1998/1999 observed in water samples collected in the Markham BMP during wet weather and dry weather events

Table 18: Baseline water chemistry measurements from 1992/1993 observed in water samples collected in the former North Pond during wet weather and dry weather events 


\section{$\underline{\text { List of Figures }}$}

Figure 1. Four general designs for constructed stormwater wetlands

Figure 2. Pond-Wetland Stormwater Management Facility in Markham, Ontario, Canada

Figure 3. Schematic of location and grid outline of plots within the Wetland Complex during field work conducted in July 2007

Figure 4. Vegetation assessment (a) overall, and in (b) cell 1, (c) cell 2, (d) cell 3, and (e) cell 4 of the Markham BMP site in July 2007. Proportions of Typha latifolia, Typha angustifolia, Scirpus tabernaemontani, and Phalaris arundinacea were determined using stem density as a measure of species abundance

Figure 5. Vegetation assessment (a) overall, and in (b) cell 1, (c) cell 2, (d) cell 3, and (e) cell 4 of the Markham BMP site in July 2007. Proportions of Typha latifolia, Typha angustifolia, Scirpus tabernaemontani, and Phalaris arundinacea were determined using biomass as a measure of species abundance

Figure 6. Invasive and native species assessment (a) overall, and in (b) cell 1, (c) cell 2, (d) cell 3, and (e) cell 4 of the Markham BMP site in July 2007. Proportions of invasive and native species were determined using stem density as a measure of abundance

Figure 7. Invasive and native species assessment (a) overall, and in (b) cell 1, (c) cell 2, (d) cell 3, and (e) cell 4 of the Markham BMP site in July 2007. Proportions of invasive and native species were determined using biomass as a measure of abundance

Figure 8. Relationships between invasive and native species (a) stem density, and (b) biomass

Figure 9. Mean values for (a) NH4-N, (b) NO3-N, (c) soil organic matter, and (d) soil pH observed in soil samples collected from each of the four wetland cells at the Markham BMP site in July 2007

Figure 10. Mean values for plant available (a) $\mathrm{P}$, (b) $\mathrm{K}$, and (c) $\mathrm{Mg}$ observed in soil samples collected from each of the four wetland cells at the Markham BMP site July 2007

Figure 11. Relationships between Typha angustifolia, Phalaris arundinacea, and Typha latifolia stem density and soil characteristics such as (a) NH4-N, (b) NO3-N, (c) soil organic matter, and (d) soil $\mathrm{pH}$ 
Figure 12. Relationships between Typha angustifolia, Phalaris arundinacea, and Typha latifolia stem density and soil characteristics such as plant available (a) P,

(b) $\mathrm{K}$, and (c) $\mathrm{Mg}$

Figure 13. Relationships between Typha angustifolia, Phalaris arundinacea, and Typha latifolia biomass and soil characteristics such as (a) NH4-N, (b) NO3-N, (c) soil organic matter, and (d) soil $\mathrm{pH}$

Figure 14. Relationships between Typha angustifolia, Phalaris arundinacea, and Typha latifolia biomass and soil characteristics such as plant available (a) $\mathrm{P}$,

(b) $\mathrm{K}$, and (c) $\mathrm{Mg}$

Figure 15. Relationships between invasive and native species stem density and soil characteristics such as (a) NH4-N, (b) NO3-N, (c) soil organic matter, and (d) soil $\mathrm{pH}$

Figure 16. Relationships between invasive and native species stem density and soil characteristics such as plant available (a) $\mathrm{P}$, (b) $\mathrm{K}$, and (c) $\mathrm{Mg}$

Figure 17. Relationships between invasive and native species biomass and soil characteristics such as (a) NH4-N, (b) NO3-N, (c) soil organic matter, and (d) soil $\mathrm{pH}$

Figure 18. Relationships between invasive and native species biomass and soil characteristics such as plant available (a) $\mathrm{P}$, (b) $\mathrm{K}$, and (c) $\mathrm{Mg}$

Figure 19. Mean values for (a) TKN, (b) water $\mathrm{pH}$, (c) DO \% saturation, (d) TDS, and (e) salinity measurements observed in water samples collected from each subsystem of the Markham BMP site in July 2007

Figure 20. The relationship between Typha angustifolia and Typha latifolia stem density and water chemistry characteristics such as (a) $\mathrm{TKN}$, (b) water $\mathrm{pH}$, (c) $\mathrm{DO} \%$ saturation, (d) TDS, and (e) salinity

Figure 21. The relationship between Typha angustifolia and Typha latifolia biomass and water chemistry characteristics such as (a) TKN, (b) water $\mathrm{pH}$, (c) DO \% saturation, (d) TDS, and (e) salinity

Figure 22. Relationships between mean invasive and native species stem density and water chemistry characteristics such as (a) $\mathrm{TKN}$, (b) water $\mathrm{pH}$, (c) $\mathrm{DO} \%$ saturation, (d) TDS, and (e) salinity

Figure 23. Relationships between mean invasive and native species biomass and water chemistry characteristics such as (a) $\mathrm{TKN}$, (b) water $\mathrm{pH}$, (c) $\mathrm{DO} \%$ saturation, (d) TDS, and (e) salinity 


\section{List of Appendices}

Appendix A: Evaluation of the relationships between environmental variables and species abundance at the Markham BMP site using multiple regression analysis

Appendix B: Raw data values for soil chemistry variables observed in soil samples collected in each of the four wetland cells at the Markham BMP site in July 2007

Appendix C: Raw data values for water chemistry variables observed in water samples collected in each subsystem at the Markham BMP site in July 2007 


\section{Chapter 1: Introduction, Background, and Research Objectives}

\subsection{Introduction to the Research Topic}

Wetlands are distinctive natural ecosystems which perform numerous functions in the environment. Over the past several decades, the value of natural processes that occur within wetlands has been recognized by scientists and environmental managers (Brix, 1994; Davis, 2000). Consequently, this has led to the increased use of constructed wetlands for wastewater and stormwater management (Tanner, 1996; Kennedy and Mayer, 2002). Currently, constructed wetlands are used for flood control, runoff volume reduction, and most notably to remove contaminants from stormwater runoff, domestic wastewater and agricultural wastewater (Brown et al., 1999; Davis, 2000; Thompson et al., 2007). Furthermore, stormwater wetlands in urban areas serve as aquatic and terrestrial habitats for various wildlife species and provide an opportunity for recreational use by the public (Magee et al., 1999; Knight et al., 2001; Sutula and Stein, 2003).

Overall, constructed wetlands can be efficient systems for stormwater treatment, habitat maintenance, and recreational activities. This efficiency is dependent on factors such as the wetland design and the natural features within these systems (Davis, 2000). Vegetation is one of these important natural components. A rich and diverse plant community is believed to enhance the efficiency and effectiveness of the natural functions and values that occur in these systems (Zedler and Kercher, 2004). However, plant community diversity may be jeopardized by an increase in the colonization of invasive species within constructed stormwater wetlands. Invasive plant species can dominate this landscape, reducing plant community diversity and thus alter and undermine ecosystem processes, functions, and health (Templer et al., 1998; Zedler and Kercher, 2004; Schooler et al., 2006). Thus, vegetation composition and abundance could be a 
visible sign of the level of function and value within stormwater wetlands (Magee et al., 1999; Thompson et al., 2007).

\subsection{Wetlands: Functions, Values, and Vegetation Characteristics}

There are multiple functions and values associated with wetlands and wetland plants. Wetland functions refer to the natural physical, chemical, and biological processes that occur within wetlands (National Research Council, 1995). Wetland values refer to the processes that are important and beneficial to society (National Research Council, 1995). In general, wetland functions and their associated societal values can be grouped into three categories: hydrology, biogeochemistry, and habitat maintenance (National Research Council, 1995; Cronk and Fennessy, 2001). Vegetation is an essential contributing component to each of these categories (Wong et al., 1999; Knight et al., 2001; Kasper and Jenkin, 2007).

In terms of hydrology, wetlands facilitate flood mitigation, groundwater recharge, and erosion reduction (National Research Council, 1995; Mitsch and Gosselink, 2000; Cronk and Fennessy, 2001). However, these functions are site specific and event specific. Wetlands have the capacity to intercept and store water temporarily and then discharge it slowly over time. In some wetlands, water seeps into the ground and recharges aquifers (Mitsch and Gosselink, 2000; Cronk and Fennessy, 2001). Furthermore, plant roots act to stabilize soils and prevent erosion during storm events (Cronk and Fennessy, 2001).

With respect to biogeochemistry, wetlands improve water quality by encouraging sediment deposition, microbial breakdown of pollutants, absorption and chelation of nutrients and metals by soil or organic compounds, plant uptake of nutrient, metals and other contaminants, and the release of oxygen to the water by plants (National Research Council, 1995; Mitsch and Gosselink, 2000; Cronk and Fennessy, 2001). These processes are enhanced 
in wetlands due to biotic and abiotic features such as shallow water levels, high primary productivity, anoxic and ananoxic soil conditions, and the accumulation of litter (Mitsch and Gosselink, 2000; Cronk and Fennessy, 2001).

Wetlands also provide and maintain wildlife habitat (National Research Council, 1995; Mitsch and Gosselink, 2000; Cronk and Fennessy, 2001). For instance, many fish, reptiles, and amphibians are dependent entirely on wetland environments (Cronk and Fennessy, 2001). Many bird populations are dependent on wetland vegetation for breeding habitats (National Research Council, 1995; Mitsch and Gosselink, 2000). This provides an economic value for hunters and commercial and sport fisheries, and an aesthetic and recreational value for the general public (National Research Council, 1995; Cronk and Fennessy, 2001).

Wetland plants are defined as species which grow in water and/or flooded or saturated soils characterized by ananoxic conditions (Cronk and Fennessy, 2001). Furthermore, wetland plants have adaptations which allow them to thrive in this environment (Cronk and Fennessy, 2001). In general, there are four types of wetland vascular plants; emergent, submerged, floating-leaved, and floating. Emergent plant species are similar to terrestrial plant species in that they are rooted belowground and stand upright. The base of these plants, their photosynthetic parts (i.e. leaves, stems) and reproductive organs are all situated aboveground (Cronk and Fennessy, 2001). Submerged plant species are those that grow entirely underwater. Some species are rooted belowground, while others have no roots (Cronk and Fennessy, 2001). Floating-leaved and floating plants species are similar in that they both have leaves which float on the water surface. However, floating-leaved species are rooted in the substrate below and their leaves are connected to the ground by submerged petioles and/or stems (Cronk and 
Fennessy, 2001). Floating species have roots which are unattached and hang in the water, and their stems also float on the water surface along with their leaves (Cronk and Fennessy, 2001).

\subsection{Constructed Wetlands}

Over the past several decades, scientists and environmental managers have come to recognize the multiple functions and values of natural wetlands (Brix, 1994). This insight has led to the development of constructed wetlands for wastewater and stormwater management (Smith et al., 1993; Shutes et al., 1997). Constructed wetlands are man-made wetland systems created at a site which did not previously contain an existing natural wetland; their purpose is to provide flood control, runoff volume reduction, and, most notably, to improve water quality from stormwater runoff (Reed, 1993; Smith et al., 1993; Brown et al., 1999; Davis, 2000; Anderson et al., 2001). Furthermore, the secondary benefits of these systems include providing potential habitats for various wildlife species in an urban environment and providing recreational opportunities for the public (Magee et al., 1999; Knight et al., 2001; Sutula and Stein, 2003).

In urban environments, stormwater runoff may contain a variety of pollutants including excess nutrients, metals, and suspended solids (Startin and Lansdown, 1994; Kasper and Jenkin, 2007). Pollutants refer to substances present in the environment that do not naturally occur in an ecosystem or occur naturally but are in excess concentrations, such that it causes adverse affects on environment and human health (Spellman, 1999).

Experimental assessments on constructed wetlands receiving urban and highway stormwater runoff have shown treatment wetlands exhibit high contaminant removal rates (Shutes et al., 1997; Kasper and Jenkin, 2007). The efficiency of these artificial environments is dependent on various factors such as wetland design and vegetation abundance and diversity (Shutes et al., 1997; Kasper and Jenkin, 2007). These features maximize contaminant removal 
from stormwater runoff through physical, chemical, and biological processes (Gearheart et al., 1999; Anderson et al., 2001).

In general, there are two main types of constructed wetlands: surface flow wetlands and subsurface flow wetlands (Brix, 1994; Gearheart et al., 1999; Davis, 2000). In Europe, many of the first treatment wetlands in the late 1970s and early 1980s were subsurface flow wetlands (Reed, 1993; Brix, 1994; Wood, 1995). These systems are still common in many European countries such as Denmark, Germany and the United Kingdom (Brix, 1994; Gearheart et al., 1999). Other countries utilizing subsurface flow wetlands include Australia and South Africa (Wood, 1995). However, in North America, surface flow wetlands are the most common type of constructed wetland for stormwater management and treatment (Brix, 1994; Wood, 1995; Davis, 2000). Throughout the 1980s and 1990s, these wetlands were built across the United States and Canada (Gearheart et al., 1999).

Surface flow wetlands are designed to mimic natural wetlands (Wood, 1995). They are characterized by shallow vegetated basins and water control structures that sustain shallow water depths (Brix, 1994; Gearheart et al., 1999; Davis, 2000). A key feature of a surface flow wetland is that water flow occurs over the bed surface (Wood, 1995; Davis, 2000). Since water levels are aboveground in this system, the water surface is exposed to the atmosphere (Brix, 1994;

Gearheart et al., 1999). As a result, water layers closer to the surface exhibit anoxic conditions, while the sediments at the bottom of these basins and deeper water layers are generally characterized by ananoxic conditions (Davis, 2000). The wetland bed may consist of soil, sand, or gravel, with sufficient depth to support the roots of emergent vegetation and prevent physical damage from stormflow events and freezing climatic conditions (Brix, 1994; Shutes et al., 1994; Gearheart et al., 1999; Davis, 2000). The design of surface flow wetlands enhances the physical, 
biological and chemical processes that occur naturally in wetlands (Gearheart et al., 1999). For instance, these treatment wetlands reduce flow velocity, increase water retention time, and increase the contact time between water and the sediment bed and/or vegetation (Gearheart et al., 1999). This in turn, facilitates the removal of pollutants such as organic matter, TSS, nutrients, metals, and pathogens, from stormwater influent (Gearheart et al., 1999).

Subsurface flow wetlands are also characterized by a vegetated basin, however water flows through the substratum, saturating the wetland bed (Reed, 1993; Brix, 1994; Wood, 1995; Davis, 2000). A key features of a this type of constructed wetland is that water flow occurs below ground, through a matrix of porous substrates such as rock, gravel or sand (Reed, 1993; Wood, 1995; Davis, 2000). Porous substrates support the roots of emergent vegetation and secure subsurface flow which can move in horizontal or vertical flow paths (Reed, 1993; Brix, 1994). Stormwater influent that flows through the porous subsurface matrix is subjected to physical, biological, and chemical processes that facilitate pollutant removal over time (Gearheart et al., 1999). These processes include adsorption to soil particles, assimilation by the plant tissue, and microbial transformations (Brix, 1994).

Overall, surface flow wetlands have lower capital and operating costs, and their construction, operation, and maintenance is straightforward compared to subsurface flow wetlands (Wood, 1995; Davis, 2000). However, these wetlands are larger and do require more land cover (Wood, 1995; Davis, 2000). On average, 60\% of surface flow wetlands in North America are $<10$ ha compared to $<0.05$ ha for subsurface flow wetlands (Brix, 1994).

\subsubsection{Various Designs for Constructed Stormwater Wetlands}

In general, constructed wetlands are usually comprised of several individual cells integrated with other systems such as sediment forebays and micropools (Shutes et al., 1997; 
Anderson et al., 2001). The sediment forebay facilitates the settling of coarse-to-medium sized particulates which enhances the pollutant removal capabilities of the wetland and controls the inflow of water into the wetland cells (Wong et al., 1999; Anderson et al., 2001). The micropool is a smaller, relatively shallow permanent pool, where finer sediments concentrate and resuspension is reduced (Anderson et al., 2001). Impermeable liners may be required under some treatment wetlands to minimize infiltration and reduce the potential risk of groundwater contamination (Anderson et al., 2001).

There are four general designs for constructed wetlands which incorporate wetland cells, micropools and forebays. They include shallow marsh wetlands, pond/wetlands, extended detention wetlands, and pocket wetlands (Anderson et al., 2001). Shallow marsh wetlands consist of low and high marsh cells with a sediment forebay and a micropool. Figure 1a illustrates the sinuous design that is characteristic of this type wetland. This design feature increases retention time and contact area which facilitates contaminant removal (Anderson et al., 2001). Furthermore, the sediment forebay reduces flow velocity and sediment loading (Anderson et al., 2001). Pond/wetlands systems consist of shallow marshes in connection with a wet pond (Anderson et al., 2001). Figure $1 \mathrm{~b}$ illustrates this multiple cells design. The wet pond is generally the first cell in the system and facilitates the removal of particulate contaminants while decreasing the flow velocity into the wetland (Anderson et al., 2001). The wet pond is followed by shallow marsh cells which facilitate the removal of soluble contaminants (Anderson et al., 2001). Overall, this system does not occupy as much space as the shallow marsh system and has the highest rate of contaminant removal in comparison to other constructed wetland designs (Anderson et al., 2001). Extended detention wetland systems consist of high marsh cells, a sediment forebay, and a micropool as illustrated in Figure 1c (Anderson et al., 2001). 


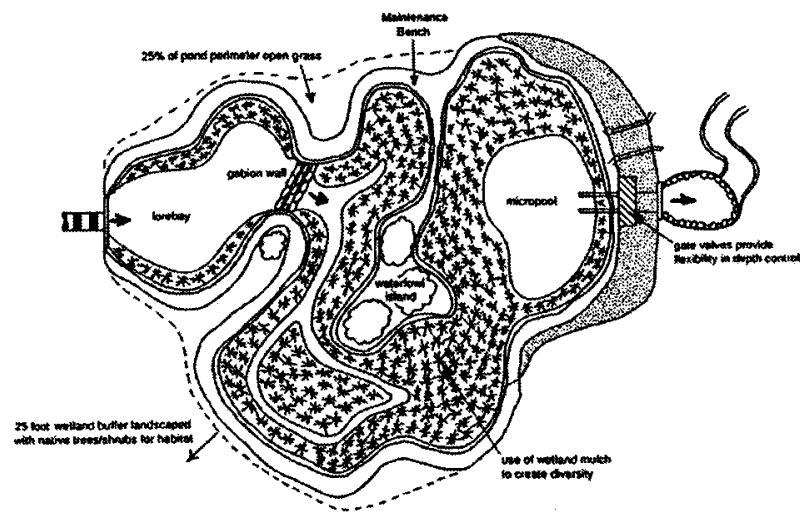

a) Shallow Marsh System

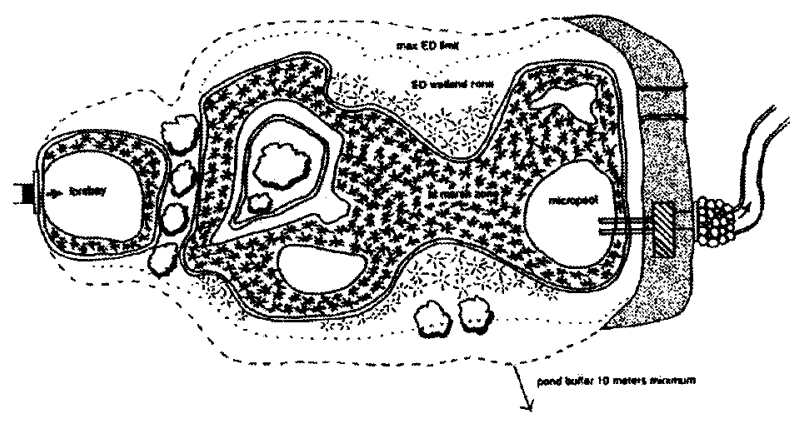

c) Extended Detention Wetland System

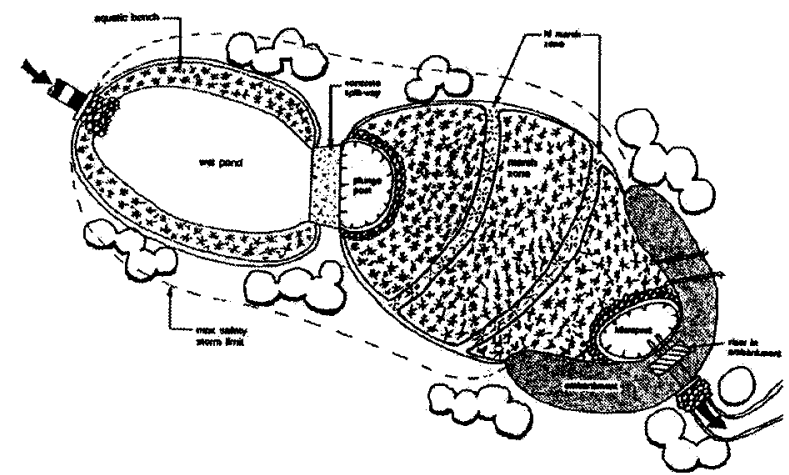

b) Pond/Wetland System

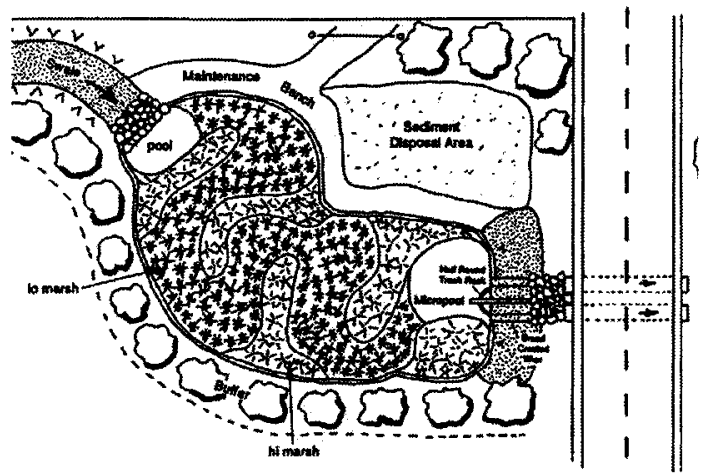

d) Pocket Wetland System

Figure 1. Four general designs for constructed stormwater wetlands (Anderson et al., 2001).

The main feature of this system is to its importance to downstream channel protection (Anderson et al., 2001). Water detention occurs above natural elevations within this system (Anderson et al., 2001). For instance, after a storm event, water within an extended detention wetland system could rise above normal levels, causing intermittent flooding (Anderson et al., 2001). Therefore, the vegetation within these flooding zones must be tolerant of such variable conditions (Anderson et al., 2001). Furthermore, this system does not occupy as much space as the shallow marsh system (Anderson et al., 2001). Pocket wetland systems consist of both low and high marsh cells. Figure 1d illustrates the multiple cell design of this type of constructed wetland. 
These systems are ideal for smaller sites and some are sustained completely by stormwater runoff (Anderson et al., 2001). However, there is the potential for these wetlands to experience times of drought (Anderson et al., 2001). Therefore, during construction of these wetlands, excavation down to the groundwater table is necessary in order to maintain sufficient water levels in the system (Anderson et al., 2001).

Wetland designs are not only important for enhancing water treatment performance, but also to mitigate contaminant exposure to wildlife (Sutula and Stein, 2003). When systems such as sediment forebays, micropools, and detention ponds are positioned before wetland cells, they are the first to intercept stormwater runoff and provide primary treatment (Sutula and Stein, 2003). This may reduce wildlife exposure to contaminants which can result in bioaccumulation and toxicity (Helfield and Diamond 1997; Sutula and Stein, 2003). However, Sutula and Stein (2003) indicate that there is a lack of literature regarding the risks of stormwater runoff to wildlife. Most often, contamination occurs at levels below acute toxicity and establishing an association between contaminant input and wildlife health is difficult (Helfield and Diamond 1997; Sutula and Stein, 2003).

\subsubsection{The Role of Vegetation in Constructed Stormwater Wetlands}

Vegetation is a vital constituent within any wetland, natural or constructed (Wong et al., 1999; Knight et al., 2001; Kasper and Jenkin, 2007). There are several important processes and functions that wetland plants perform. In terms of physical processes and functions, plants are responsible for stabilizing substrates and sediments, restricting channelized flow, and reducing water velocity (Brown et al., 1999; Wong et al., 1999; Davis, 2000; Kasper and Jenkin, 2007). These processes facilitate the settling of suspended material and removal of pollutants (Brown $e t$ al., 1999; Wong et al., 1999; Davis, 2000; Kasper and Jenkin, 2007). 
In terms of biochemical processes and functions, vascular plants take up and assimilate substances (i.e. carbon, nutrients, metals, and trace elements) into their tissues through the root zone (Wood, 1995; Brown et al., 1999; Wong et al., 1999; Davis, 2000; Stottmeister et al., 2003). This is dependent on the type of plant and the nature of the chemical species (Brown et al., 1999). Plants also generate oxygenated microsites within substrates, and provide microbial attachment sites on stems and root systems (Wood, 1995; Davis, 2000; Stottmeister et al., 2003). For instance, plants may be covered with a biofilm layer containing microorganisms which adsorb materials (Brown et al., 1999). Furthermore, photosynthesis by plants increases dissolved oxygen levels within wetlands which, in turn, influences reactions involving nutrients and metals (Brown et al., 1999; Davis, 2000).

In North America, vegetation, such as bulrushes (Scirpus spp.), cattails (Typha spp.), and reeds (Phragmites spp.), are commonly planted in constructed wetlands (Brown et al., 1999; Knight et al., 2001; Bonilla-Warford and Zedler, 2002; Sutula and Stein, 2003). The suitability of plant species for use in constructed wetlands is determined based on factors such as their ecological acceptability (i.e. native), tolerance to stressors (i.e. climate, pest, diseases, and pollutants), ability to establish and propagate rapidly, and high capacity for pollutant removal (Tanner, 1996).

\subsection{Invasive Plant Species in Wetland Communities}

A major nuisance to wetland plant communities, in particular native species, in both natural and constructed wetlands is invasive wetland plants (Cronk and Fennessy, 2001). Invasive wetland plants are species, generally non-native, that rapidly grow in abundance and distribution, often dominating landscapes they colonize (Cronk and Fennessy, 2001; Zedler and Kercher, 2004). Thus, once established, invasive species have the ability to reduce native 
wetland plant diversity which in turn may alter ecological processes and functions, and diminish their societal values (National Research Council, 1995; Cronk and Fennessy, 2001; Zedler and Kercher, 2004). This is of particular importance for constructed stormwater wetlands whose purpose is based on the effectiveness and efficiency of natural wetland processes and functions.

Wetlands are subject to various hydrological disturbances (i.e. flood pulse, surface runoff etc.) which influence wetland features such as water flow, canopy gaps, ananoxic soils, and nutrient influxes (Zedler and Kercher, 2004). Moreover, hydrological disturbances are largely associated with the build up of excess water, nutrients, sediments, heavy metals, and other contaminants in these ecosystems (Zedler and Kercher, 2004). Thus, these conditions often enhance the vulnerability of wetlands to invasive plant species and are often associated with a reduction in native plant species quantity and quality (Galatowitsch et al., 1999; Houlahan and Findlay, 2004; Zedler and Kercher, 2004; Schooler et al., 2006).

Furthermore, invasive wetland plant species themselves are successful due to characteristics such as seed and propagule dispersal via flotation, capability to aerate the rhizosphere layer of the soil, and rapid nutrient uptake and growth (Mitsch and Gosselink, 2000; Kennedy and Mayer, 2002; Zedler and Kercher, 2004). In general, wetland invasion can be explained by several hypotheses. Two of these, the Efficient Use Hypothesis and the Broader Tolerance Hypothesis, suggest invasion as a function of interspecific competition and environmental conditions respectively. The Efficient Use Hypothesis suggests that invasive species have a greater competitively ability for resources such as light and nutrients (Zedler and Kercher, 2004). For instance, in Sweden, the invasive Typha angustifolia has a greater competitive ability for light, and in the United States, the invasive Phalaris arundinacea demonstrates enhanced competitive ability with increasing $\mathrm{NO}_{3}-\mathrm{N}$ concentrations (Weisner, 
1993; Green and Galatowitsch, 2002). The Broader Tolerance Hypothesis suggests that invasive species are able to tolerate a wider range of environmental conditions compared to other species (Zedler and Kercher, 2004). For instance, in the United States, the invasive T. angustifolia and P. arundinacea have greater tolerance to increased salinity levels and fluctuations in water levels respectively (Panno et al., 1999; Kercher and Zedler, 2004a; Miklovic and Galatowitsch, 2005).

Regardless of the methods of invasion, invasive plant species impact several components of wetland environments including habitat structure, food webs, productivity, nutrient cycling, microorganisms, and, most importantly, plant diversity. These impacts alter ecological processes and functions within wetlands, and diminish their societal value (National Research Council, 1995; Cronk and Fennessy, 2001; Zedler and Kercher, 2004).

Recently, there have been several studies examining the impacts of invasive plant species on native species composition and abundance in natural wetland environments. Schooler et al. (2006) explored the impact of purple loosestrife (Lythrum salicaria) and reed canary grass $(P$. arundinacea) in 24 wetlands across the Pacific Northwest, USA. Results indicated that these two invasive plant species were able to reduce the diversity of plant communities within these environments. Similarly, Houlahan and Findlay (2004) examined the relationship between native plant species and invasive plant species in 58 inland wetlands across Ontario, Canada. Results indicated that the invasive species reduced native plant species abundance and should be managed in order to preserve wetland diversity. Overall, it seems invasive species have a tendency to dominate wetland environments and reduce the number of native species (Templer $e t$ al., 1998; Houlahan and Findlay, 2004; Zedler and Kercher, 2004; Schooler et al., 2006). Thus, as invasive species populations increase, the richness and diversity of other plant species in wetlands is expected to decrease (Houlahan and Findlay, 2004; Schooler et al., 2006). 
The reduction in plant biodiversity that is associated with increasing invasive plant species, can alter wetland processes, functions, and values (National Research Council, 1995; Cronk and Fennessy, 2001; Zedler and Kercher, 2004). This includes altering water quality functions, hydrological functions, nutrient cycling, wildlife habitat structure, and aesthetic and recreational value for the general public (National Research Council, 1995; Mitsch and Gosselink, 2000; Cronk and Fennessy, 2001).

\subsection{Research Objectives and Significance}

The overall goal of this study is to improve understanding of invasive species and their relationship and impact on vegetation composition and abundance within constructed stormwater wetlands. Factors such as the type of native and invasive plants that establish within the wetland, and the abundance of these various plant species are all important considerations. Increasing native species communities is recommended since these plants have the ability to foster diversity by encouraging the growth of additional native species (Sutula and Stein, 2003; Boer et al., 2007). Maximizing plant diversity in constructed stormwater wetlands is believed to improve the effectiveness and efficiency of water quality functions, enhance habitat quality for wildlife, and create recreational opportunities for the public, thus enhancing the benefits and value of these facilities (Bonilla-Warford and Zedler, 2002; Sutula and Stein, 2003).

In general, the Efficient Use Hypothesis and the Broader Tolerance Hypothesis suggest that vegetation composition and abundance is a function of interspecific competition between plant species and environmental factors respectively (Wetzel and van der Valk, 1998; Zedler and Kercher, 2004). Therefore, the specific objectives of this study were to: 1) identify emergent plant species composition and abundance (both invasive and native); 2) investigate the relationship between the invasive emergent plant species and native emergent plant species 
within the wetland complex; and 3) investigate the influence environmental factors may have on plant species composition and the presence or abundance of invasive species.

The results of this study could be used to further understand and quantify the impacts invasive plant species have on plant community dynamics in constructed stormwater wetlands. It is essential for constructed wetland managers to understand these impacts in order for them to make viable management decisions regarding the design, performance, and maintenance of vegetation communities within these systems. It also facilitates the development of practical and well-organized planting strategies for future endeavours. 


\section{Chapter 2: Methodology}

\subsection{Study Site}

The site used for this study was the Markham Best Management Practice Demonstration facility, commonly referred to as the Markham BMP. Located in Markham, Ontario, Canada, this particular stormwater management facility is on the Upper Morningside Tributary of the Rouge River Watershed and covers approximately 9.1 ha (SWAMP, 2002). It was constructed in 1997 and is actually a retrofit of a smaller stormwater marsh known as the North Pond (SWAMP, 2002). The facility was commissioned by the Town of Markham, the Ontario Ministry of the Environment (formerly the Ontario Ministry of Environment and Energy), and the Great Lakes Sustainability Fund of the Government of Canada (SWAMP, 2002).

The design of the Markham BMP is that of a pond/wetland system. It is comprised of a sediment forebay, followed by a wet pond, and a wetland complex (Figure 2). The wetland complex is a surface flow constructed wetland consisting of four alternating cells (Figure 2). This wetland subsystem alternates between cells with a constant pool of water and cells with full vegetation cover (Figure 2). Overall, this facility treats stormwater runoff from a 600 hectare drainage basin which is several times larger than other conventional single-subdivision stormwater facilities in Ontario (SWAMP, 2002). Pond/wetland systems are considered to have the highest rates of stormwater contaminant removal compared to most other constructed wetland designs (Anderson et al., 2001).

The Markham BMP is situated to the north of a new residential development. Each of the subsystems within the facility is surrounded by a meadow fringe. There are trails that run between the wet pond and wetland complex which allow public access to the facility (Figure 2). It was common to see local residents leisurely walking their dogs through the facility. Wildlife, 
such as birds and amphibians, was also present within the Markham BMP and frequently seen throughout field work conducted for this study. In terms of the surrounding area, the topography consists of gently rolling hills and the soils consist of silty-sand loams (SWAMP, 2002).

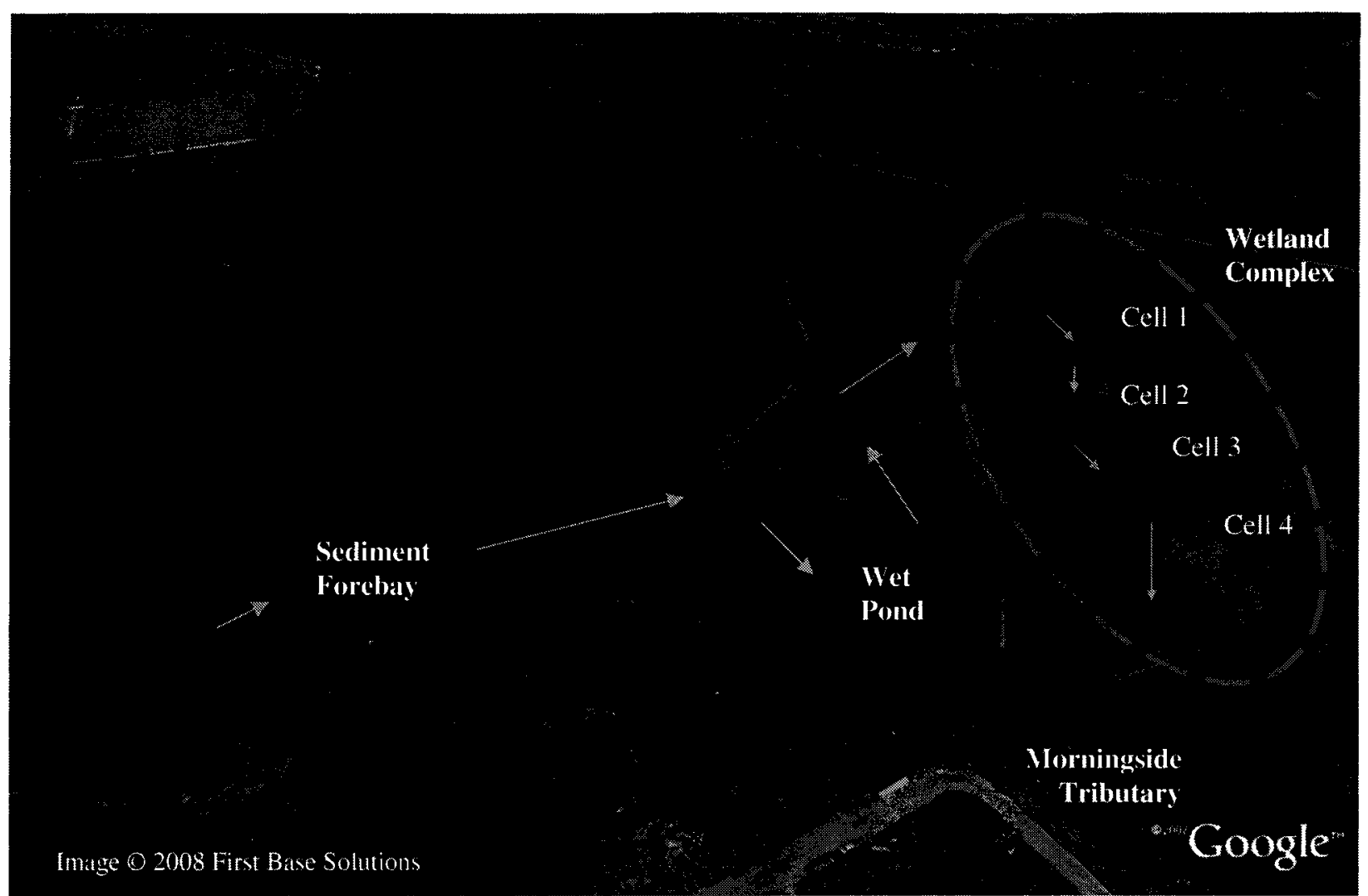

Figure 2. Pond-Wetland Stormwater Management Facility in Markham, Ontario, Canada (Google Earth Pro, 2008). Arrows represent the normal flow path of water through the facility. Public access trails are visible between the Wet Pond and Wetland Complex.

Furthermore, during this study period, there was active construction of a residential and commercial area adjacent the stormwater facility to the south. North of the facility, most of the residential and commercial development was already complete. Commercial and residential land use construction around the Markham BMP has been ongoing over the past decade. By 2002, approximately $67 \%$ of the drainage area had been partly or fully developed (SWAMP, 2002). Of 
the $67 \%$ urban land use, $90 \%$ represented residential development and $10 \%$ represent industrial development (SWAMP, 2002). It was estimated that the drainage area for the Markham BMP would be fully developed within 5 to 10 years, with the exception of residential park lands and zones deemed environmentally significant (SWAMP, 2002).

The Markham BMP was designed for important functions such as the removal of stormwater pollutants, flood peak attenuation, base-flow augmentation, and downstream erosion control. In particular, the wetland portion of this facility serves several functions including sedimentation, biological uptake, filtration, and microbial transformation of contaminants (SWAMP, 2002). Furthermore, this constructed wetland provides a habitat for wildlife and has maintained and enhanced wildlife diversity in the area (SWAMP, 2002).

In June 2002, a performance assessment study on the Markham BMP was produced by Stormwater Assessment Monitoring and Performance (SWAMP) Program for the Great Lakes Sustainability Fund of the Government of Canada, the former Ontario Ministry of the Environment and Energy, the Toronto and Region Conservation Authority, the Municipal Engineers Association, and the Town of Markham (SWAMP, 2002). The objective of the SWAMP program was to monitor and evaluate stormwater management technologies and to publish results and recommendations. Therefore, the purpose of the SWAMP Markham BMP study was to achieve a comprehensive evaluation of the facility's performance by assessing system characteristics such as hydrology, water quality, downstream erosion, and vegetation. Monitoring of the facility was conducted from November 1998 to December 1999 and April to June 2000 (SWAMP, 2002). Results suggested that the Markham BMP met or exceeded most of its performance targets and objectives including flood attenuation, efficient stormwater pollutant removal, and modest mitigation of downstream erosion (SWAMP, 2002). 
In terms of vegetation, the strategy used to promote the establishment of plants in the wetland complex of the Markham BMP was to use sediments and the associated seedbank of the former marsh. Furthermore, biodiversity was to have been introduced after construction by the planting of seedlings (SWAMP, 2002). However, this planting program was never implemented (SWAMP, 2002). As a result, according to the vegetation surveys conducted in July 2000, the wetland complex was dominated by Typha latifolia (85-90\%) and Phalaris arundinacea (8$13 \%)$.

\subsection{Vegetation Sampling}

Vegetation surveys were conducted between July 3 and July 18, 2007, when the majority of emergent vascular plants had completed growing for the season (Hager and Vinebrooke, 2004). As discussed in section 1.2, there are four types of wetland plants; emergent, submerged, floating-leaved, and floating. Although constructed stormwater wetlands may contain all four types of wetland plants, there was a lack of observable submerged, floating-leaved, and floating species at the Markham BMP site. Furthermore, these species can be more difficult to accurately identify compared to emergent plant species (Cronk and Fennessy, 2001). Therefore, this study focused exclusively on the surveying of emergent wetland plant species.

A random sampling design was used to sample emergent vegetation in each of the four cells in the wetland complex. Each cell contained two plots which consisted of a grid of subplots. However, due to sampling limitations created by the open water bodies in Cell 1 and Cell 3, plots had to be located on opposite sides in these cells. Furthermore, although Cell 2 and Cell 4 did not have any open water body constraints, to maintain consistency the same configuration was used in these cells (Figure 3). 
For Cell 2 and Cell 4, the sampling design consisted of a grid of two subplots by three subplots. These six subplots were spaced $1 \mathrm{~m}$ apart and each subplot measured $2.0 \mathrm{~m} \mathrm{X} 0.5 \mathrm{~m}$ (Figure 3; Hager and Vinebrooke, 2004). The first subplot was placed randomly, $1 \mathrm{~m}$ from the edge of the wetland cell. From there, the sampling design extended three subplots into the wetland and two subplots wide. The long edge of each individual subplot was parallel to the edge of the wetland cell (Hager and Vinebrooke, 2004). In total, Cell 2 and Cell 4 contained 12 subplots each.

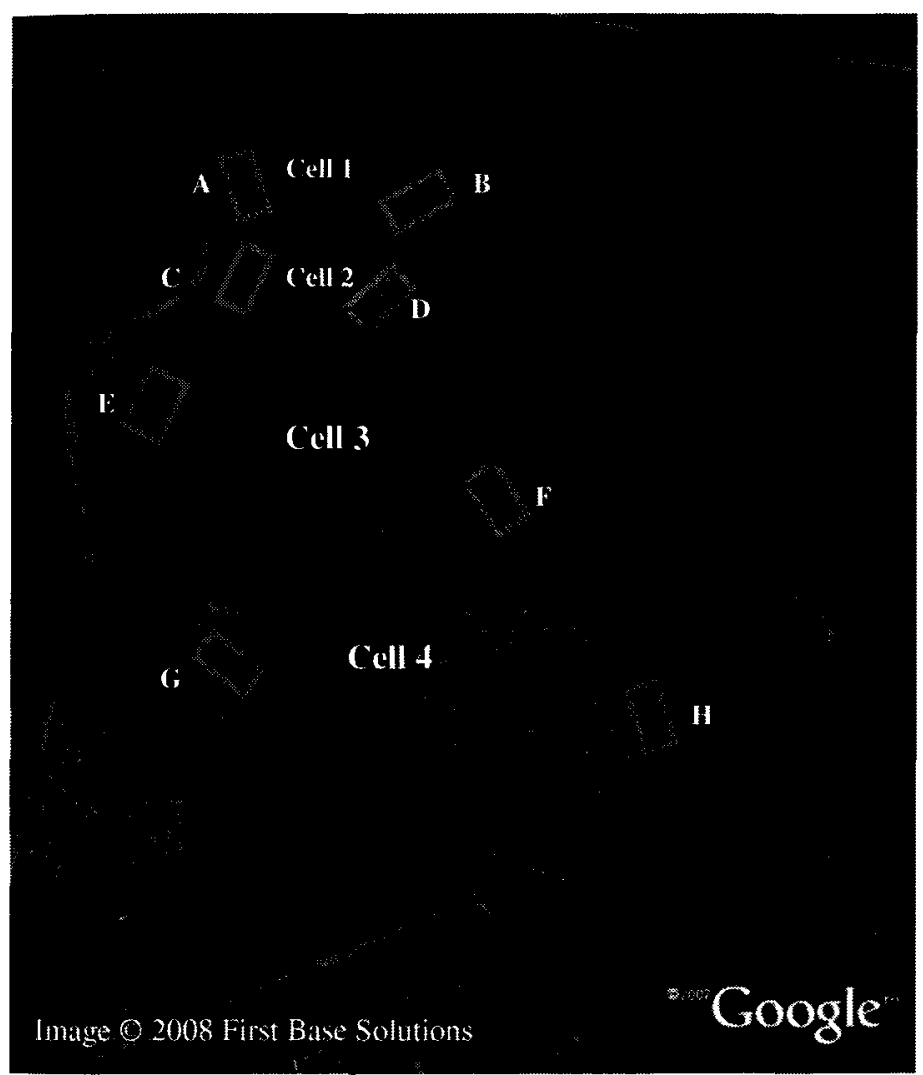

\section{Cell 1 and Cell 3 \\ (Plots A, B, E and F)}

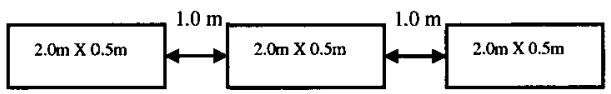

Cell 2 and Cell 4

(Plots C, D, G and H)

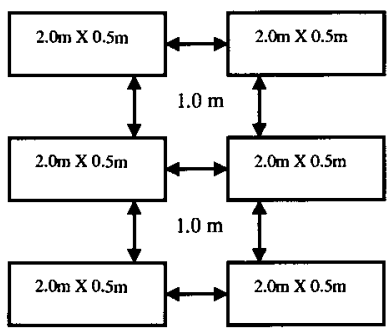

Figure 3. Schematic of location and grid outline of plots within the Wetland Complex during field work conducted in July 2007 (Google Earth Pro, 2008). Plots in Cell 2 and Cell 4 were divided into 6 subplots. Plots in Cell 1 and Cell 3 were divided into 3 subplots. This modification was necessary due to open water body constraints. 
Due to the large areas of open water, the sampling design for Cell 1 and Cell 3 was modified slightly. It consisted of a grid of one subplot by three subplots. The three subplots were also spaced $1 \mathrm{~m}$ apart and each measured $2.0 \mathrm{~m} \mathrm{X} 0.5 \mathrm{~m}$ (Figure 3; Hager and Vinebrooke, 2004). The first subplot was placed randomly, $1 \mathrm{~m}$ from the edge of the wetland cell. From there, the sampling design extended one subplot into the wetland and three subplots wide. The long edge of each individual subplot was parallel to the edge of the wetland cell (Hager and Vinebrooke, 2004). In total, Cell 1 and Cell 3 contained 6 subplots each.

Overall there were 36 subplots sampled in this study. Within each of the subplots, species composition (i.e. species list) and species abundance (i.e. stem density and biomass) was determined. These are considered common descriptions of vegetation by plant ecologists (National Research Council, 1995). The emergent vascular plant species were identified using nomenclature from Crow and Hellquist (2005), and their stem density and average stem height were recorded. The only species identified in the subplots were Typha angustifolia, T. latifolia, P. arundinacea, and Scirpus tabernaemontani. This supports visual observations of cells characterized by monocultures of Typha spp., signifying a lack of biodiversity in the wetland complex.

Furthermore, two $0.1 \mathrm{~m} \mathrm{X} 0.5 \mathrm{~m}$ strips of aboveground standing crop were cut from each subplot (Hager and Vinebrooke, 2004). These samples were sorted into bundles based on live standing crop for T. angustifolia, T. latifolia, $P$. arundinacea, and S. tabernaemontani and the total dead standing crop. Bundles were left to air dry over a few weeks before they were brought back to the laboratory. In the laboratory, all plant material was dried at approximately $100^{\circ} \mathrm{C}$ in a large drying oven for 24 hours. After drying was complete, samples were weighed in order to 
determine the biomass for the live standing crop of individual species and for the total dead standing crop.

\subsection{Environmental Variables}

\subsubsection{Soil Sampling}

In addition to vegetation surveys, soils samples were collected from each of the 36 individual subplots during the same sampling period. At the center of each subplot, soil samples were taken to a depth of $18 \mathrm{~cm}$. The soil samples were placed into small plastic bags and homogenized. These samples were then immediately frozen and kept in this condition until they were brought to the University of Guelph's Soil and Nutrient Laboratory for analysis of basic soil chemistry. At this accredited soil testing laboratory, ammonium $\left(\mathrm{NH}_{4}-\mathrm{N}\right)$, nitrate $\left(\mathrm{NO}_{3}-\mathrm{N}\right)$, soil organic matter, soil $\mathrm{pH}$, plant available phosphorus $(\mathrm{P})$, plant available potassium $(\mathrm{K})$, and plant available magnesium $(\mathrm{Mg})$ concentrations were determined for each sample. These are the soil characteristics which are commonly analyzed in similar studies and are known to be associated with plant growth and productivity (SWAMP, 2002; Houlahan et al., 2006; Schooler et al., 2006).

\subsubsection{Water Sampling}

Water chemistry characteristics were also considered in this study. Water sampling was conducted on three separate occasions; one day representing a wet weather event, and two days representing a dry weather event. A wet weather event occurred when there was rainfall with at least $1 \mathrm{~cm}$ of rain during a 24 hour period. Dry weather events occurred when there was no rainfall during a period of several days. One more day of sampling was intended for a wet weather event. However due to the extremely warm and dry conditions experienced during the 
summer of 2007, rainfall events were sparse and there was insufficient precipitation for this final sample to be collected.

Composite water samples were taken from the forebay, wet pond, and in each of the four cells of the wetland complex. During each water sampling period, there were 6 samples collected in total, one for each subsystem. Water from various locations in and around each subsystem was collected in 1 L Nalgene bottles. Using a Hanna HI 9828 multi-parameter portable water quality meter, water $\mathrm{pH}$, dissolved oxygen (DO), total dissolved solids (TDS), and salinity were all measured in situ and recorded. These are water chemistry characteristics which have been analyzed in similar studies and were able to be measured directly using the water quality meter (Goslee et al., 1997; Panno et al., 1999; Borin et al., 2001; Kennedy and Mayer, 2002). The water samples were then immediately frozen and kept in this condition until they were brought to the University of Guelph's Soil and Nutrient Laboratory for further analysis of basic water chemistry. At this accredited laboratory, total Kjeldahl nitrogen (TKN), dissolved phosphorus $(\mathrm{P})$, copper $(\mathrm{Cu})$, and zinc $(\mathrm{Zn})$ concentrations were determined for each sample. TKN and $\mathrm{P}$ are water chemistry characteristics which have been analyzed in similar studies, and $\mathrm{Cu}$ and $\mathrm{Zn}$ represent common metal contaminants found in urban stormwater runoff (Kennedy and Mayer, 2002; SWAMP, 2002; Houlahan et al., 2006).

\subsection{Data Analysis}

The data collected through field and laboratory assessments were evaluated using various descriptive and statistical approaches. In MS Excel (2003), the composition and overall abundance of species in the wetland complex was determined using stem density and biomass data obtained through the vegetation surveys. The proportions of $T$. angustifolia, $T$. latifolia, $P$. arundinacea, and $S$. tabernaemontani stem density and biomass were calculated for each of the 
four cells that comprise the wetland complex and for the subsystem as a whole. Furthermore, these four species were categorized as either invasive or native, and the same analysis was conducted for the corresponding data set. Pie graphs were generated to provide a visual interpretation of these results.

Bar graphs were generated to illustrate the differences and trends in soil and water chemistry parameters among the Markham BMP subsystems. This is of particular importance for water chemistry parameters. If the wetland complex is functioning efficiently, then a reduction in the concentrations of variables associated with pollutants, such as TKN or salinity, should be observed as water passes through the system. Furthermore, if any differences in vegetation composition and abundance are observed among wetland cells, then identifying potential differences in the soil chemistry parameters among these cells will be important since these variables have some potential influence on vegetation growth within the wetland complex. Mean differences between soil and water chemistry parameters were assessed using either an analysis of variance (ANOVA) or the non-parametric Kruskal Wallis Test in SPSS 13.0 (2004). First, the data were checked for normal distribution and homogeneity of variances (Morgan et al., 2004). If the data satisfied these assumptions for an ANOVA, then an analysis of variance was conducted. If the overall $F$-value of the ANOVA was significant $(P<0.05)$, than a post hoc comparison was conducted. In such cases, Tukey's honest significant difference (HSD) was used to compare the means (Morgan et al., 2004). However, if the assumptions for an ANOVA were violated (i.e. distributions were skewed and variances were unequal), then a Kruskal Wallis Test was conducted (Morgan et al., 2004). Similarly, if the Kruskal Wallis Tests were statistically significant $(P<0.05)$, than a post hoc comparison was conducted and Mann Whitney Tests were used to compare the means (Morgan et al., 2004). The Bonferroni 
correction was applied to the significance level of these tests by dividing 0.05 by 6 (Morgan $e t$ al., 2004). Therefore, in order for Mann Whitney Tests to be statistically significant, a value of $P$ must be $<0.0083$.

Scatterplots were created in MS Excel (2003) in order to determine if there were any relationships between species abundance (i.e. stem density and biomass) and environmental variables (i.e. soil and water chemistry parameters). Species abundance measures for $T$. angustifolia, T. latifolia, and $P$. arundinacea were used in the correlation analysis. There were only two subplots that contained S. tabernaemontani. Thus, this sample size was too small for a correlation analysis to be conducted on this species. All four species were then categorized as either invasive or native, and the same analysis was conducted for the corresponding data set. A correlation analysis was also conducted to investigate the presence of a relationship between invasive and native species stem density and biomass.

For each scatterplot, linear trend lines were generated and the correlation coefficients (r) were calculated. A critical value of the Correlation Coefficient (r) table was utilized for evaluating the significance of the correlations. Using this table, coefficients were considered significant at $P<0.05$ (Zar, 1999). Furthermore, to supplement the evaluation of the correlations between environmental variables and species abundance, multiple regressions were conducted using SPSS 13.0 (2004). The results of this analysis can be found in Appendix A. 


\section{Chapter 3: Results}

\subsection{Assessment of Individual Species in the Wetland Complex}

An assessment of individual species in this study involved an evaluation of composition and abundance for each cell of the wetland complex. Species composition was determined through vegetation surveys. The vegetation community of the wetland complex was composed of four emergent plant species: Typha angustifolia, Typha latifolia, Phalaris arundinacea, and Scirpus tabernaemontani. This supports visual observations which acknowledged the presence of these four emergent plant species and also recognized a lack of biodiversity within the wetland complex. During field sampling, no other species were observed visually or through vegetation surveying. Furthermore, in terms of species abundance, all four cells were characterized by virtual monocultures of Typha spp., and there was an overall lack of biodiversity within the wetland complex of the Markham BMP.

\subsubsection{Species Composition within the Wetland Complex}

The following are brief descriptions of the four emergent wetland plant species identified in the wetland complex of the Markham BMP during vegetation sampling conducted in July 2007.

\section{Typha angustifolia}

T. angustifolia, narrow-leaved cattail, is an emergent rhizomatous perennial plant found in wetlands (Grace and Harrison, 1986; Tiner, 1987; NRCS, 2006b). They form dense stands and can grow to $1-3 \mathrm{~m}$ in height (Grace and Harrison, 1986; Tiner, 1987). They have a cylindrical inflorescence comprised of a staminate (male) and a pistillate (female) flower separated by a 1 to $8 \mathrm{~cm}$ gap (Grace and Harrison, 1986; NRCS, 2006b). The pistillate flower is 
a cinnamon brown cigar-shaped structure, up to $2.0 \mathrm{~cm}$ in diameter (Grace and Harrison, 1986; Cox, 2002; NRCS, 2006b). The staminate flower is a yellow spire-shaped structure (Cox, 2002; NRCS, 2006b). Flowering occurs from late May through July (Tiner, 1987). Around the base of the flowering stalks, leaves form a sheath (Tiner, 1987; Cox, 2002). As the basal leaves grow upward, they spread away from flowering head. These leaves are long, slender, approximately 4 to $12 \mathrm{~mm}$ wide, and deep green in colour (Grace and Harrison, 1986; Cox, 2002; NRCS, 2006b).

Prior to 1820 , vegetation surveys conducted across the eastern United States (i.e. New York, Boston, and Philadelphia) did not document the presence of any T. angustifolia (Galatowitsch et al., 1999). It is believed that this plant species arrived from Europe during the European settlement of the U.S. east coast. By 1886, T. angustifolia had become established in wetland environments along the Atlantic coast (Galatowitsch et al., 1999).

From 1900 this species has steadily migrated to inland wetlands (Grace and Harrison, 1986; Galatowitsch et al., 1999). By 1949, T. angustifolia range included Quebec, Ontario, and 19 states from Maine to North Dakota, Missouri to Pennsylvania (Galatowitsch et al., 1999). Furthermore, from 1949 to 1967, its expansion continued westward into southeastern Manitoba, Montana, and northeastern Colorado (Galatowitsch et al., 1999). This species is considered invasive and aggressive, especially when hydrology, salinity, or fertility changes occur within a wetland (NRCS, 2006b). They displace native plant communities and establish extensive monocultures (NRCS, 2006b).

\section{Typha latifolia}

T. latifolia, broad-leaved cattail, is also an emergent rhizomatous perennial plant found in wetlands (Grace and Harrison, 1986; NRCS, 2006a). They form dense stands and can grow to 1$3 \mathrm{~m}$ in height (Grace and Harrison, 1986; Tiner, 1987). This species also has a cylindrical 
inflorescence comprised of a staminate (male) and a pistillate (female) flower (Grace and Harrison, 1986; NRCS, 2006a). However, unlike T. angustifolia, there is no separation between male and female flowers (Tiner, 1987; NRCS, 2006a). The pistillate flower is a dark brown cigar-shaped structure, up to $3.5 \mathrm{~cm}$ in diameter (Grace and Harrison, 1986; Cox, 2002; NRCS, 2006a). The staminate flower is a yellow spire-shaped structure (Cox, 2002; NRCS, 2006a). Flowering occurs from late May through to July (Tiner, 1987). For T. latifolia, leaves also form a sheath around the base of the flowering stalks. However, their leaves are wider (up to $2.5 \mathrm{~cm}$ ), and bluish-green in colour (Grace and Harrison, 1986; Tiner, 1987; Cox, 2002).

T. latifolia is a native wetland plant species and is common to temperate regions, especially eastern North America (Grace and Harrison, 1986; Cox, 2002; NRCS, 2006a). They have an exceptional competitive ability which allows them to dominate wetland environments (NCRS, 2006a). T. latifolia is tolerant of fluctuations in water levels and moderate salinity levels in soils (NRCS, 2006a).

\section{Phalaris arundinacea}

P. arundinacea, reed canary grass, is a perennial wetland plant (Schooler et al., 2006). They form dense stands and can also grow to be anywhere from 0.6 to $2.7 \mathrm{~m}$ in height (NRCS, 2006c). The flowering heads consist of a compact panicle, ranging from 7.6 to $40 \mathrm{~cm}$ in size (NRCS, 2006c). Flowering occurs from June through August (Tiner, 1987). Flowers are green to purple but change to beige by the end of the growing season. Leaves are flat and tapered, approximately 9 to $25 \mathrm{~cm}$ long (NRCS, 2006c).

There is some dispute regarding the true origins of $P$. arundinacea (NRCS, 2006c; Schooler et al., 2006). Some studies have suggested there are native and non-native genotypes of $P$. arundinacea (NRCS, 2006c). Galatowitsch et al. (1999) believed that the origin of this 
species cannot be positively determined and thus they are a cryptogenic species. Cultivation of P. arundinacea in temperate regions of North American and Europe occurred around 1835 (Galatowitsch et al., 1999). It is thought that $P$. arundinacea has mixed origins due to the hybridization of North American and European varieties (Schooler et al., 2006; Galatowitsch et al., 1999). In Europe, there was interest in the cultivation of this plant as early as 1749 (Galatowitsch et al., 1999). However, uncertainty in the pre-agricultural distribution of $P$. arundinacea stems from its early cultivation (Galatowitsch et al., 1999).

Despite the uncertainty in origin, $P$. arundinacea is considered an invasive species (NRCS, 2006c; Schooler et al., 2006). It has a superior competitive ability which allows it to out-compete other species in wetland environments (NCRS, 2006a). Furthermore, it can be an aggressive invader, especially when there is an increase in nutrient concentrations and increased sedimentation (Schooler et al., 2006).

\section{Scirpus tabernaemontani}

S. tabernaemontani, soft-stem bulrush, is an emergent perennial plant found in wetlands (Tiner, 1987; NRCS, 2006d). Also referred to as Scirpus validus and Schoenoplectus tabernaemontani, their stems are soft but stand erect and taper to a point (Tiner, 1987). They can grow to up to $3 \mathrm{~m}$ in height (Tiner, 1987; NRCS, 2006d). Flowers are reddish brown in colour and located on dropping spikelet clusters (Tiner, 1987; NRCS, 2006d). Flowering occurs from June into September (Tiner, 1987). Leaves may not be apparent, but they form long sheaths that are held closely along the stem of the plant (Tiner, 1987; NRCS, 2006d). S. tabernaemontani leaves and stems are grayish green in colour (Tiner, 1987).

S. tabernaemontani is a native wetland plant species and is common all over North America, especially the northeastern regions (Tiner, 1987). This species usually establishes in 
environments with poorly drained soils; however, constant periods of prolonged draining and flooding can decrease stands (NCRS, 2006d). Furthermore, S. tabernaemontani is tolerant of a wide range of saline conditions (NRCS, 2006d).

\subsubsection{Species Abundance within the Wetland Complex}

Individual species abundance was determined using the measures of stem density and biomass. Overall, the wetland complex was lacking in biodiversity and was characterized by a virtual monoculture of $T$. angustifolia.

\section{Vegetation Assessment Using Stem Density}

The wetland complex was dominated by Typha spp. (Figure 4). In particular, this site was dominated by the presence of $T$. angustifolia, which comprised $81 \%$ of the emergent plants sampled. The site also contained T. latifolia, which comprised $10 \%$ of the emergent plants sampled. The remaining emergent plants sampled were comprised of $7 \%$. arundinacea and $2 \%$ S. tabernaemontani (Figure 4a).

In terms of the wetland cells; Cell 1, Cell 2, Cell 3 and Cell 4 were all dominated by $T$. angustifolia with 78\%, 76\%, 76\%, and 89\% respectively (Figure 4b-e). Overall, Cell 4 contained a higher proportion of $T$. angustifolia compared to the other cells in this complex. $T$. latifolia was also present in all four cells, with the highest proportion (24\%) sampled in Cell 3 (Figure 4d). P. arundinacea was only present in Cell 2 and Cell 4 with $15 \%$ and $7 \%$ respectively (Figure $4 \mathrm{c}$ and $4 \mathrm{e}$ ). These cells were fully vegetated and did not maintain a constant pool of water. S. tabernaemontani was only present in Cell 1 and comprised $14 \%$ of the plant species sampled in this cell (Figure 4b). 

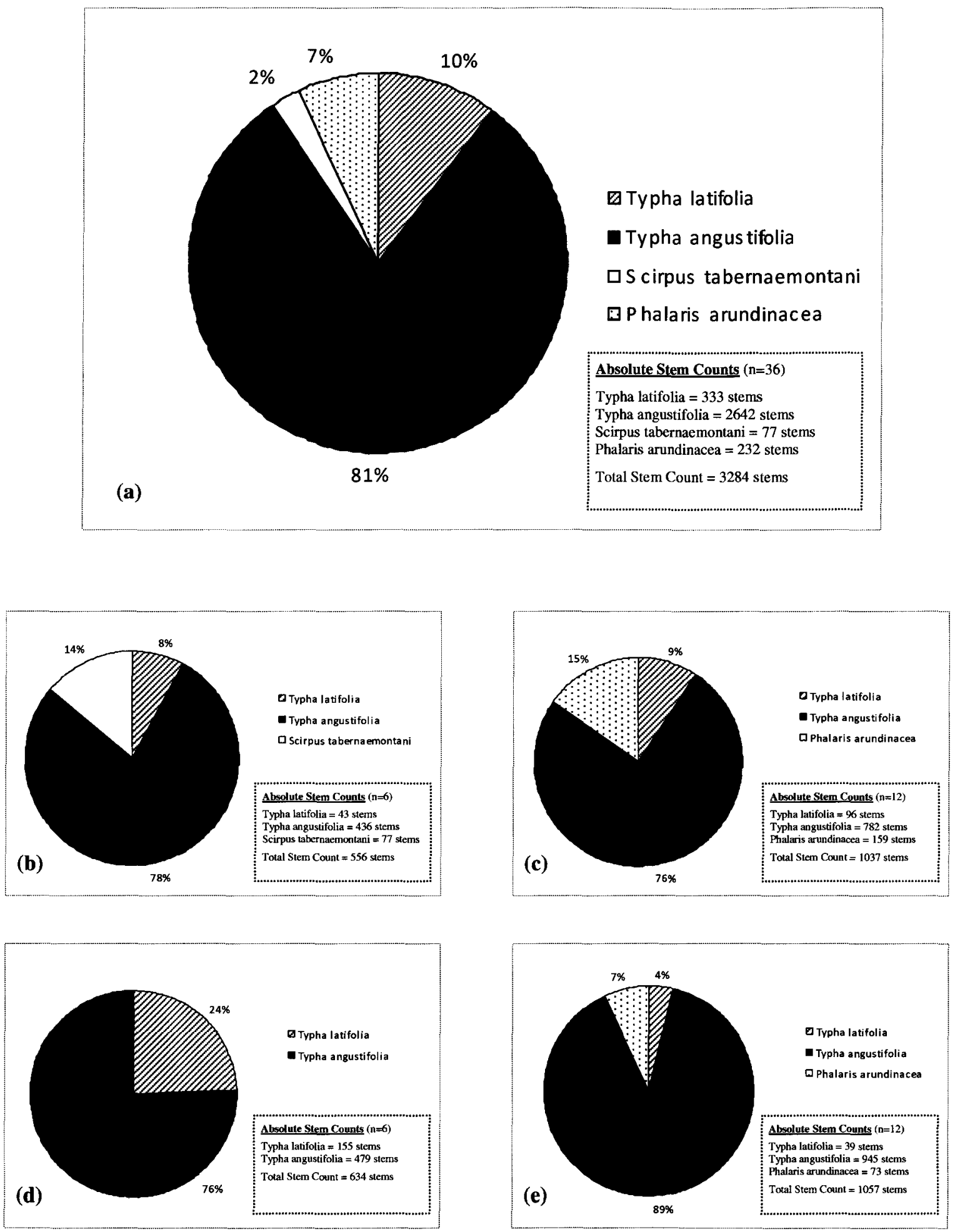

Figure 4. Vegetation assessment (a) overall, and in (b) cell 1, (c) cell 2, (d) cell 3, and (e) cell 4 of the Markham BMP site in July 2007. Proportions of Typha latifolia, Typha angustifolia, Scirpus tabernaemontani, and Phalaris arundinacea were determined using stem density as a measure of species abundance. 


\section{Vegetation Assessment Using Biomass}

The biomass in the wetland complex was primarily dominated by Typha spp. (Figure 5). T. angustifolia comprised $70.7 \%$ of the plants sampled. T. latifolia comprised $26.8 \%$ of the plants sampled in the wetland complex. Both the biomass of $P$. arundinacea and $S$. tabernaemontani were much smaller having only $2.3 \%$ and $0.2 \%$ respectively (Figure $5 \mathrm{a}$ ).

In terms of the wetland cells; Cell 1, Cell 2, and Cell 4 were dominated by $T$. angustifolia biomass with $81.3 \%, 71.4 \%$ and $89.4 \%$ respectively (Figure 5b, 5c, and 5e). However, Cell 3 was dominated by $T$. latifolia biomass with $60.5 \%$ (Figure 5d). The proportion of $P$. arundinacea biomass found in Cell 2 and Cell 4 was small, with $5.6 \%$ and $1.4 \%$ respectively (Figure $5 \mathrm{c}$ and $5 \mathrm{e}$ ). In Cell $1, S$. tabernaemontani biomass only comprised $1.5 \%$ of the plants sampled (Figure 5b).

\subsection{Assessment of Invasive and Native Species in the Wetland Complex}

An assessment of invasive and native species in this study involved an evaluation of vegetation composition and abundance for each cell of the wetland complex. It also included an evaluation of the relationship between invasive and native species in order to identify potential interspecific competition between plant species. The Efficient Use Hypothesis suggests that vegetation composition and abundance is a function of interspecific competition (Wetzel and van der Valk, 1998; Zedler and Kercher, 2004).

\subsubsection{Invasive and Native Species Composition and Abundance within the Wetland Complex}

Invasive and native species composition was determined through vegetation surveys. Invasive species composition consisted of $T$. angustifolia and $P$. arundinacea, and native species composition consisted of T. latifolia and S. tabernaemontani. Invasive and native species 

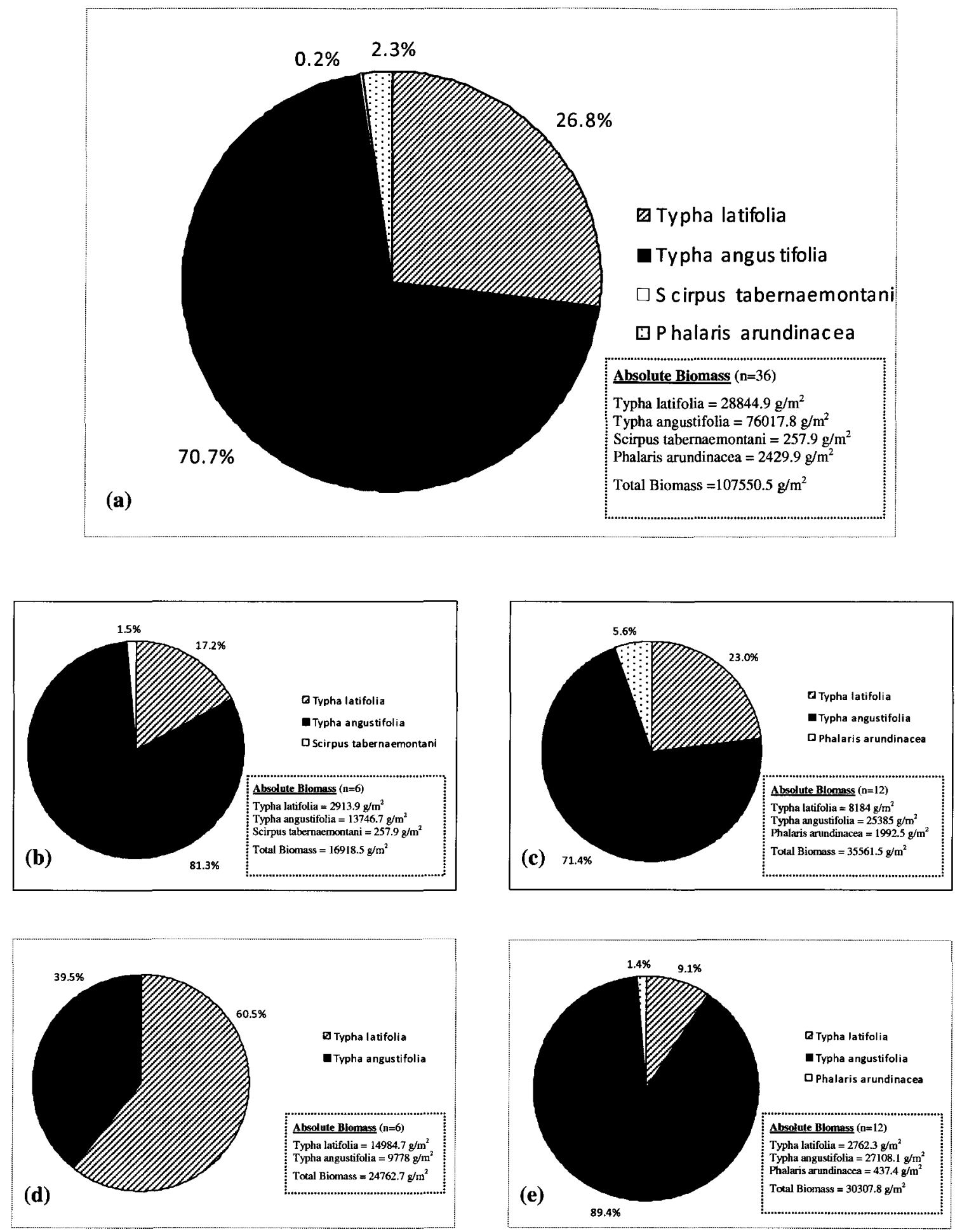

Figure 5. Vegetation assessment (a) overall, and in (b) cell 1, (c) cell 2 , (d) cell 3, and (e) cell 4 of the Markham BMP site in July 2007. Proportions of Typha latifolia, Typha angustifolia, Scirpus tabernaemontani, and Phalaris arundinacea were determined using biomass as a measure of species abundance. 
abundance was determined using the measures of stem density and biomass. In general, the wetland complex of the Markham BMP was dominated by invasive species, especially virtual monocultures of $T$. angustifolia.

\section{Vegetation Assessment Using Stem Density}

The wetland complex was dominated by invasive plant species $T$. angustifolia and $P$. arundinacea (Figure 6). Together, invasive plants comprised of $88 \%$ of the plants sampled, while native species comprised of only $12 \%$ of the plants sampled (Figure 6a).

In terms of the wetland cells; Cell 1, Cell 2, Cell 3 and Cell 4 were all dominated by invasives with $78 \%, 91 \%, 76 \%$, and 96\% respectively (Figure 6b-e). Overall, Cell 2 and Cell 4 contained the highest proportion of invasives (Figure $6 \mathrm{c}$ and $6 \mathrm{e}$ ). These cells were fully vegetated and did not maintain a constant pool of water. Native species only accounted for $22 \%$ of the plants sampled in Cell 1,9\% of the plants sampled in Cell 2,24\% of the plants sampled in Cell 3, and $4 \%$ of the plants sampled Cell 4 (Figure 6b-e).

\section{Vegetation Assessment Using Biomass}

In general, the biomass in the wetland complex was primarily dominated by invasive plant species (Figure 7). Together, the proportion of invasive species biomass comprised $73 \%$ of the plants sampled, while native species comprised $27 \%$ of the plants sampled (Figure 7 a). In terms of the wetland cells; Cell 1, Cell 2, and Cell 4 were dominated by invasive biomass with $81 \%, 77 \%$ and $91 \%$ respectively (Figure $7 \mathrm{~b}, 7 \mathrm{c}$, and $7 \mathrm{e}$ ). In contrast, native species biomass dominated with $61 \%$ (Figure $7 \mathrm{~d}$ ). 

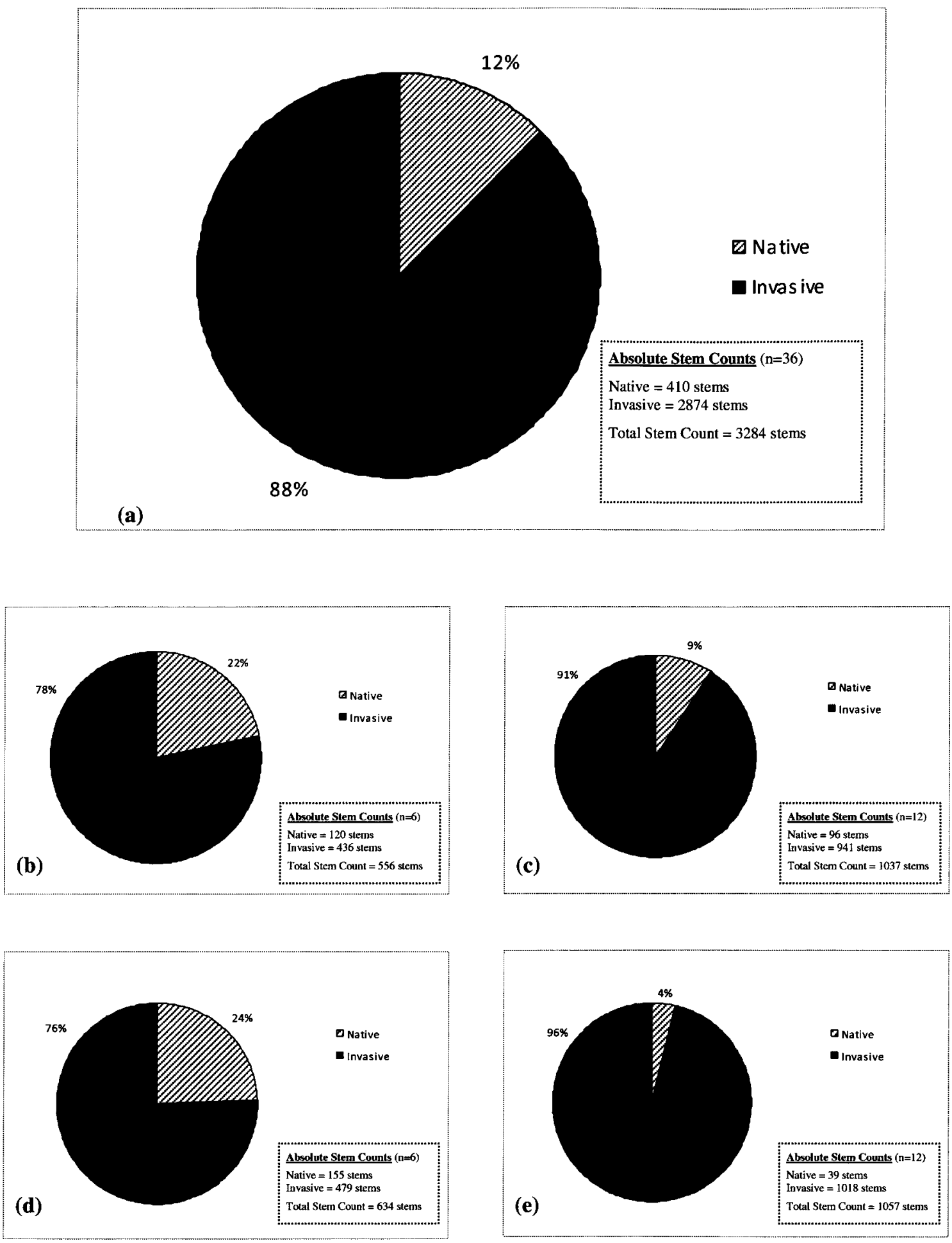

Figure 6. Invasive and native species assessment (a) overall, and in (b) cell 1, (c) cell 2, (d) cell 3, and (e) cell 4 of the Markham BMP site in July 2007. Proportions of invasive and native species were determined using stem density as a measure of abundance. 

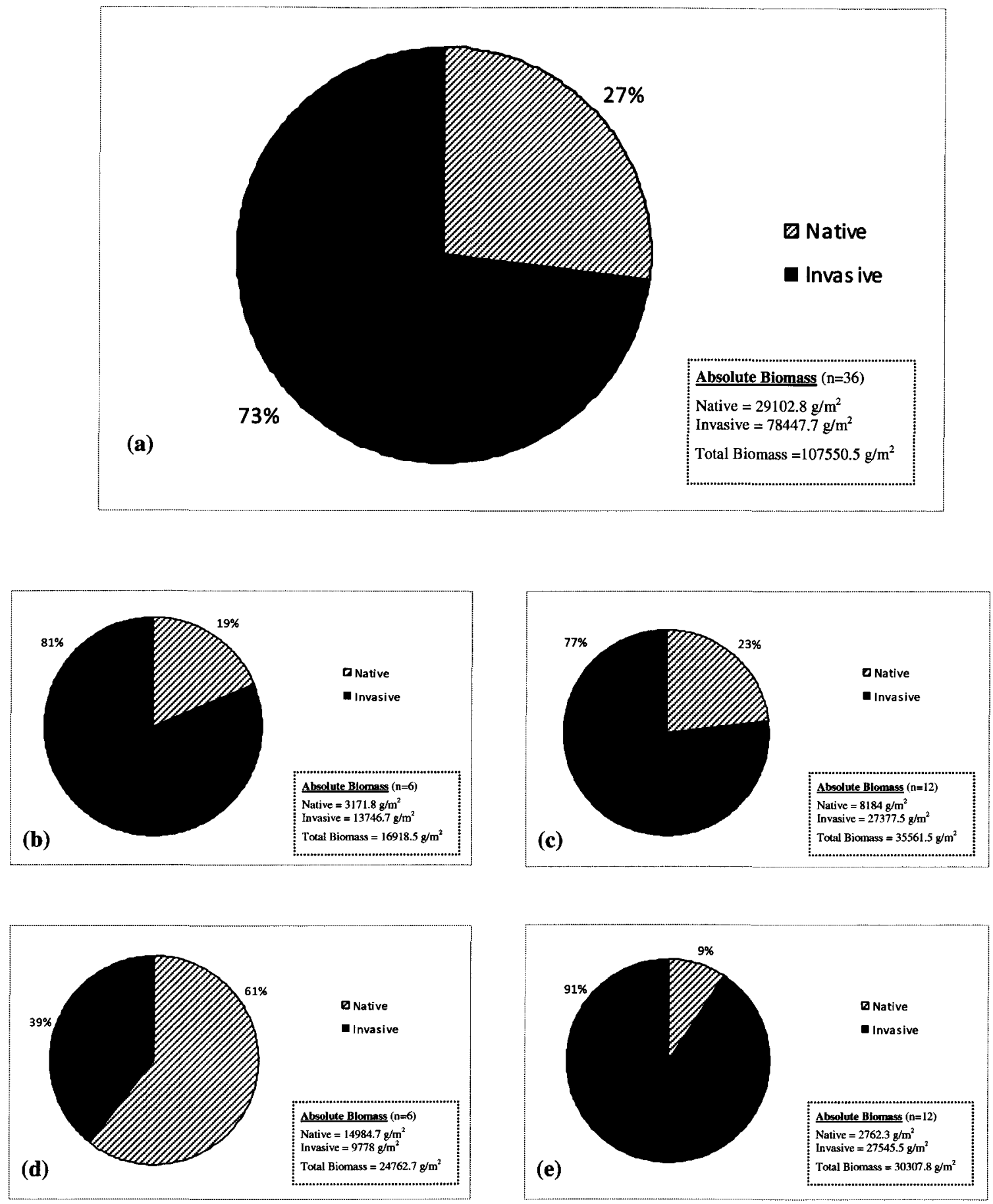

Figure 7. Invasive and native species assessment (a) overall, and in (b) cell 1, (c) cell 2, (d) cell 3, and (e) cell 4 of the Markham BMP site in July 2007. Proportions of invasive and native species were determined using biomass as a measure of abundance. 


\subsubsection{Relationship between Invasive and Native Species within the Wetland Complex}

There were relationships observed in a correlation analysis between the invasive and native plant species stem density and biomass (Figure 8). The relationship for invasive and native plant species stem density and biomass generated correlation coefficient values of $\mathrm{r}=0.5331$ and $\mathrm{r}=0.5861$ respectively (Figure $8 \mathrm{a}$ and $8 \mathrm{~b}$ ). There were statistically significant associations between invasive and native plant species stem density $\left(r_{0.05,35}=0.5331, P<0.01\right)$ and invasive and native plant species biomass $\left(r_{0.05,35}=0.5861, P<0.01\right)$. The direction of the correlations were both negative, implying, not surprisingly, that native plant species stem density decreases with increasing invasive plant species stem density, and that native plant species biomass decreases with increasing invasive plant species biomass.

\subsection{Environmental Relationships within the Wetland Complex}

An assessment of environmental relationships in this study involved an analysis of soil chemistry and water chemistry within the wetland complex and an evaluation of the correlations between these variables and species abundance. The Broader Tolerance Hypothesis suggests that vegetation composition and abundance is a function of environmental factors (Wetzel and van der Valk, 1998; Zedler and Kercher, 2004).

Raw data values for both soil chemistry and water chemistry variables observed in samples collected at the Markham BMP are found in Appendix B and Appendix C respectively. All of the soil chemistry variables were used in the assessment of environmental relationships within the wetland complex. However, there were some water chemistry variables, such as dissolved $\mathrm{P}, \mathrm{Cu}$, and $\mathrm{Zn}$, that could not be used in this assessment. Measurements for these variables were below detectable limits and therefore no trends or correlations could be determined. 

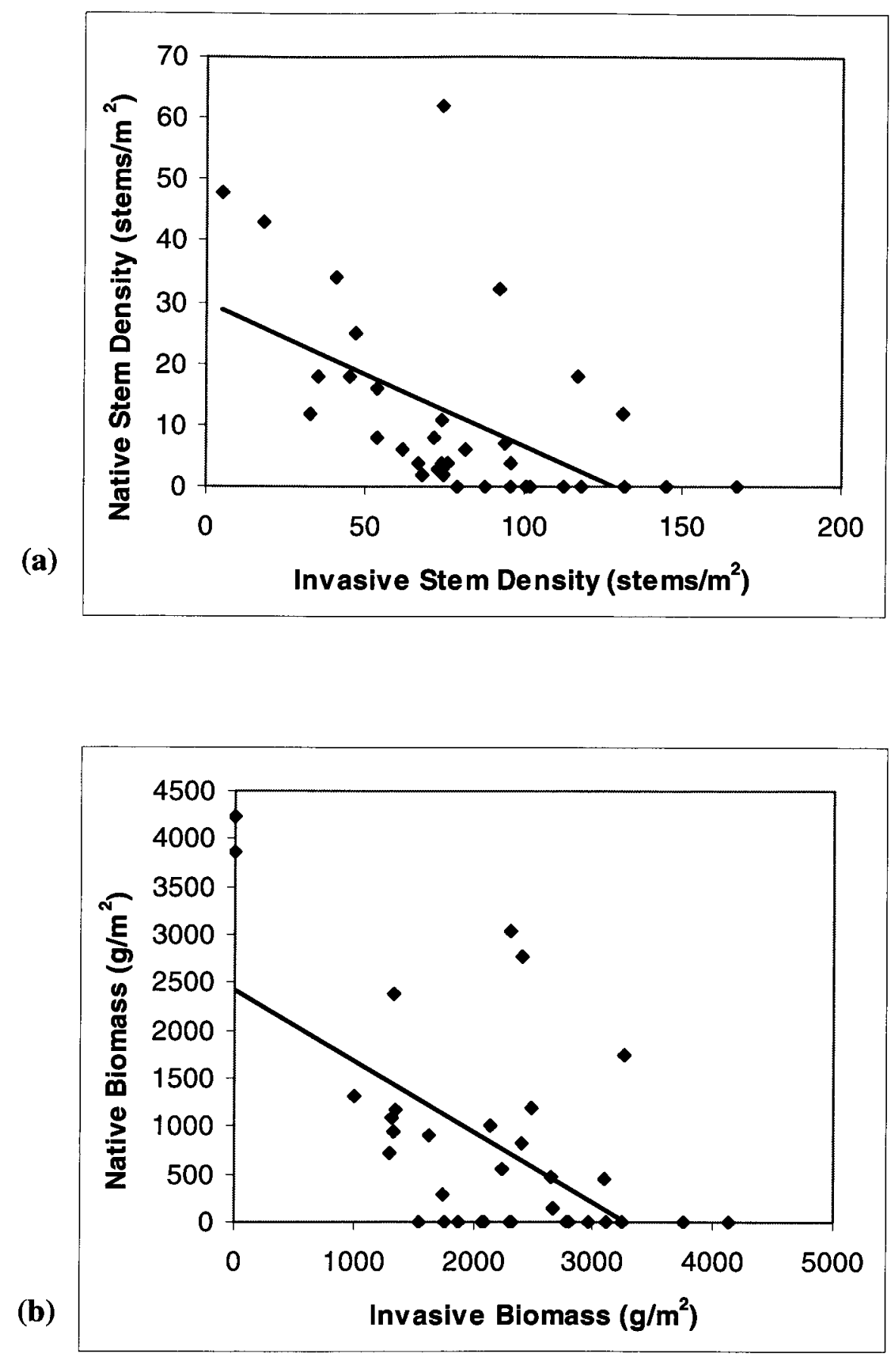

Figure 8. Relationships between invasive and native species (a) stem density, and (b) biomass. Sample size was $n=36$ for invasive and native species stem density and biomass. Significant correlations occurred between invasive and native species (a) stem density $\left(r_{0.05,35}=0.5331, P<0.01\right)$, and (b) biomass $\left(r_{0.05,35}=0.5861, P<0.01\right)$. 


\subsubsection{Potential Trends in Soil Chemistry Variables between Wetland Cells of the Markham BMP}

Mean $\mathrm{NH}_{4}-\mathrm{N}, \mathrm{NO}_{3}-\mathrm{N}$, soil organic matter, soil $\mathrm{pH}$, plant available $\mathrm{P}$, plant available $\mathrm{K}$, and plant available Mg measurements for samples collected in Cell 1, Cell 2, Cell 3, and Cell 4 are listed in Table 1.

Table 1: Mean $\pm 1 \mathrm{SE}$ values for soil chemistry variables observed in soil samples collected in each of the four wetland cells at the Markham BMP site in July 2007.

\begin{tabular}{|c|c|c|c|c|c|c|c|c|}
\hline \multicolumn{2}{|c|}{ Subsystem } & $\begin{array}{c}\mathbf{N H}_{4}-\mathbf{N} \\
(\mathbf{m g} / \mathbf{k g} \mathbf{d r y})\end{array}$ & $\begin{array}{c}\mathrm{NO}_{\mathbf{3}}-\mathrm{N} \\
(\mathrm{mg} / \mathrm{kg} \mathrm{dry})\end{array}$ & $\begin{array}{c}\text { Soil } \\
\text { Organic } \\
\text { Matter } \\
\text { (\% dry) }\end{array}$ & Soil pH & $\begin{array}{c}\text { Plant } \\
\text { Available } P \\
\text { (mg/L soil) }\end{array}$ & $\begin{array}{c}\text { Plant } \\
\text { Available K } \\
\text { (mg/L soil) }\end{array}$ & $\begin{array}{c}\text { Plant } \\
\text { Available } \mathbf{M g} \\
\text { (mg/L soil) }\end{array}$ \\
\hline Cell 1 & $n=6$ & $29.20 \pm 10.95$ & $0.16+0.09$ & $6.90 \pm 2.14$ & $7.72 \pm 0.07$ & $17.33+1.45$ & $77.00 \pm 6.57$ & $128.33+11.32$ \\
\hline Cell 2 & $\mathrm{n}=12$ & $13.38 \pm 1.83$ & $0.16 \pm 0.08$ & $6.34 \pm 0.58$ & $7.74 \pm 0.03$ & $24.25 \pm 1.38$ & $76.42 \pm 5.27$ & $144.75 \pm 7.37$ \\
\hline Cell 3 & $n=6$ & $65.34 \pm 15.17$ & $0.19 \pm 0.07$ & $7.45 \pm 1.70$ & $7.68 \pm 0.03$ & $25.83 \pm 3.73$ & $71.33 \pm 9.22$ & $133.33 \pm 9.37$ \\
\hline Cell 4 & $\mathrm{n}=12$ & $6.68 \pm 3.25$ & $0.48 \pm 0.11$ & $2.58 \pm 0.82$ & $7.88 \pm 0.04$ & $10.17 \pm 0.92$ & $49.00 \pm 3.86$ & $94.83 \pm 6.22$ \\
\hline
\end{tabular}

There were no consistent trends observed when examining the amounts of $\mathrm{NH}_{4}-\mathrm{N}, \mathrm{NO}_{3}-$

$\mathrm{N}$, soil organic matter, and soil $\mathrm{pH}$ in each cell of the constructed wetland complex (Figure 9).

However, there seemed to be significant differences in soil chemistry composition for Cell 4.

$\mathrm{NH}_{4}-\mathrm{N}$ values suggest that Cell 4 had lower amounts of $\mathrm{NH}_{4}-\mathrm{N}$ compared to all other cells, especially Cell 1 and Cell 3 (Figure 9a). Furthermore, Kruskal Wallis Tests revealed that there were statistically significant differences in values between cells $\left(X_{0.05,3}^{2}=17.457, P=0.001\right)$. Thus, Cell 4 contained a significantly lower amount of $\mathrm{NH}_{4}-\mathrm{N}$ compared to Cell 1 (Mann Whitney Test, $P=0.019$ ), Cell 2 (Mann Whitney Test, $P=0.06$ ) and Cell 3 (Mann Whitney Test, $P=0.001)$.

$\mathrm{NO}_{3}-\mathrm{N}$ values suggest that Cell 4 had higher amounts of $\mathrm{NO}_{3}-\mathrm{N}$ compared to the other cells in the wetland complex (Figure 9b) and Kruskal Wallis Tests revealed that these differences 
(a)

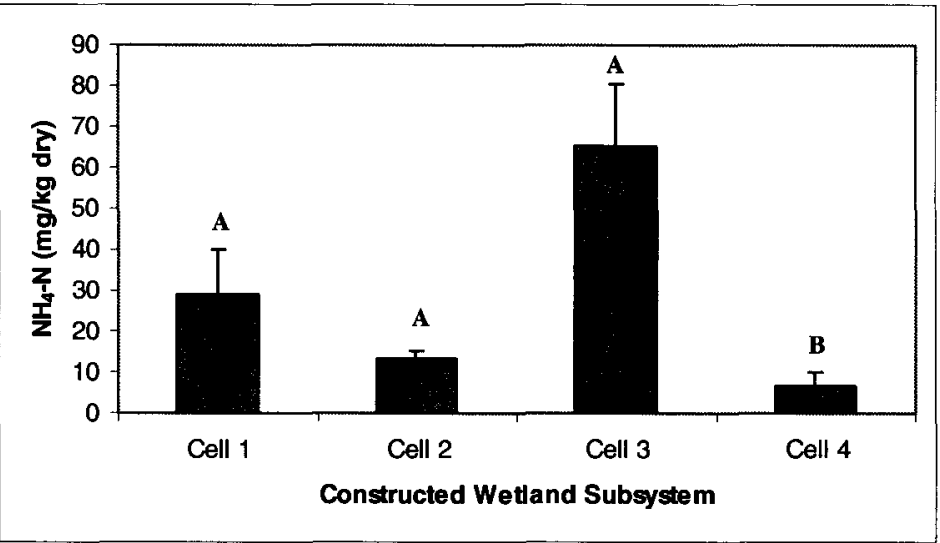

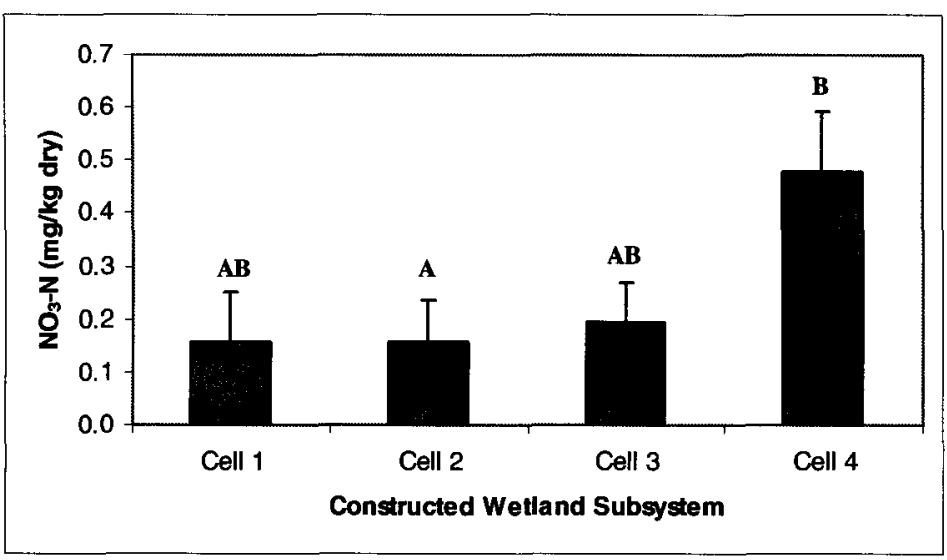

(c)

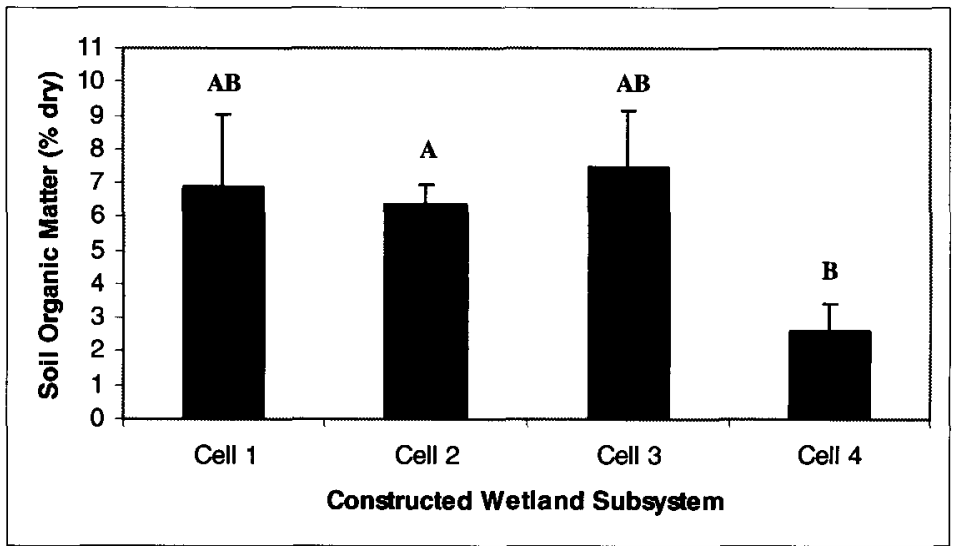

(d)

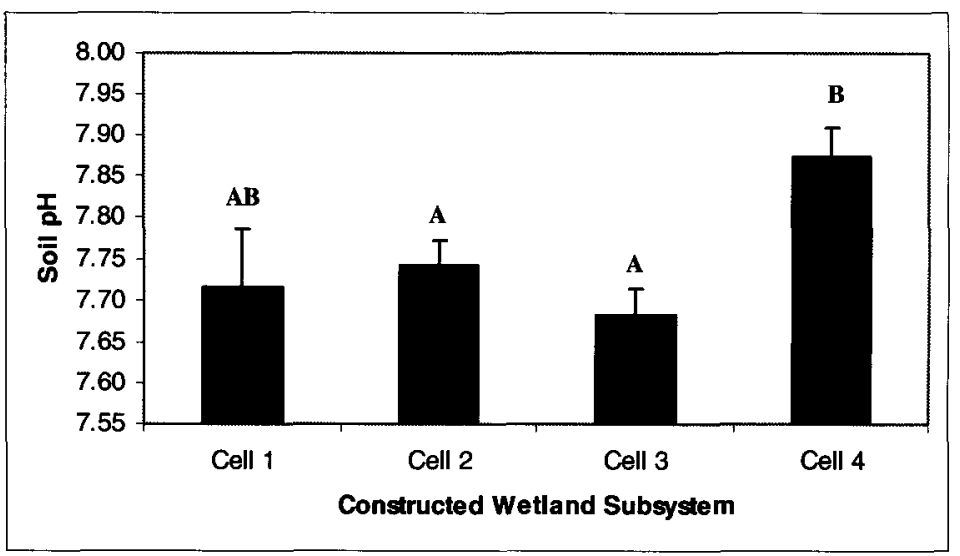

Figure 9. Mean values for (a) $\mathrm{NH}_{4}-\mathrm{N}$, (b) $\mathrm{NO}_{3}-\mathrm{N}$, (c) soil organic matter, and (d) soil pH observed in soil samples collected from each of the four wetland cells at the Markham BMP site in July 2007. Error bars represent the standard error of the mean. Sample size was $n=6$ for Cell 1 and Cell 3 was and $\mathrm{n}=12$ for Cell 2 and Cell 4. Differences between means with the same letters are not statistically significant (Kruskal Wallis Test, $P<0.05$ ). 
were statistically significant $\left(X_{0.05,3}^{2}=8.881, P=0.031\right)$. In particular, Cell 4 contained significantly higher amounts of $\mathrm{NO}_{3}-\mathrm{N}$ compared to Cell 2 (Mann Whitney Test, $P=0.006$ ).

Soil organic matter values suggest that Cell 4 had lower amounts of soil organic matter compared to all other cells in the wetland complex (Figure 9c). Furthermore, Kruskal Wallis Tests revealed that these differences were in fact statistically significant $\left(X_{0.05,3}^{2}=12.364\right.$, $P=0.006$ ). Specifically, Cell 4 contained significantly lower amounts of soil organic matter compared to Cell 2 (Mann Whitney Test, $P=0.004$ ).

Soil $\mathrm{pH}$ values suggest that Cell 4 had slightly higher $\mathrm{pH}$ levels compared to all other cells in the wetland complex (Figure 9d). Kruskal Wallis Tests revealed that this differences was statistically significant $\left(X_{0.05,3}^{2}=11.10, P=0.011\right)$. The $\mathrm{pH}$ levels in Cell 4 were significantly different than Cell 2 (Mann Whitney Test, $P=0.008$ ) and Cell 3 (Mann Whitney Test, $P=0.005$ ). However, although the differences may have been statistically significant, they were not considerable as all cells demonstrate somewhat neutral conditions.

In terms of plant available nutrients, there also were no consistent trends observed when examining the amounts of $\mathrm{P}, \mathrm{K}$, and $\mathrm{Mg}$ in each cell of the constructed wetland complex (Figure 10). However, there were significant differences in the concentration of plant available nutrients in Cell 4.

Plant available $\mathrm{P}$ values suggest that Cell 4 had lower amounts of $\mathrm{P}$ compared to all other cells, especially Cell 2 and Cell 3 (Figure 10a). Kruskal Wallis Tests revealed that there were statistically significant differences in values between cells $\left(X_{0.05,3}^{2}=24.794, P<0.001\right)$. Thus, Cell 4 contained significantly lower concentrations of P compared to Cell 1 (Mann Whitney Test, $P=0.002$ ), Cell 2 (Mann Whitney Test, $P<0.0083$ ) and Cell 3 (Mann Whitney Test, $P=0.001$ ). 


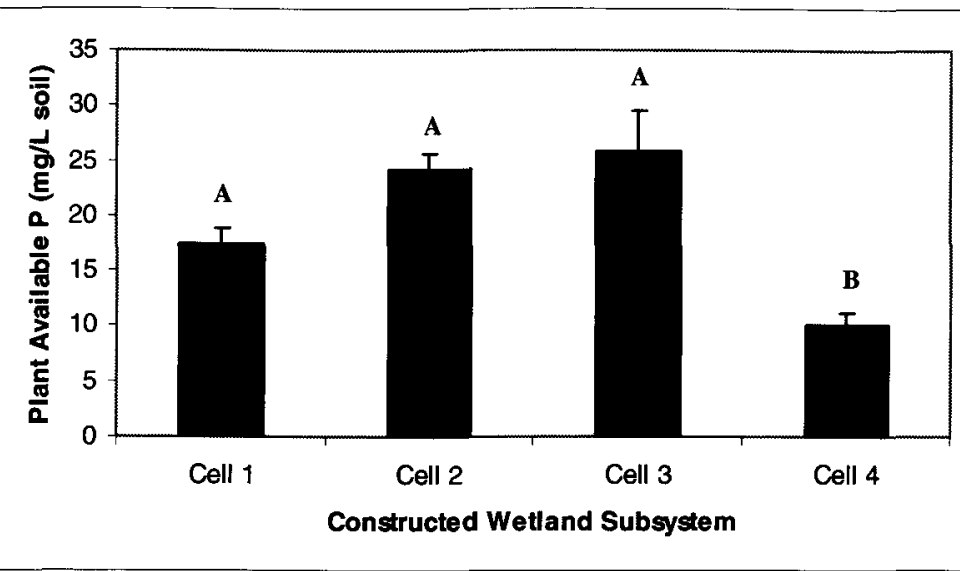

(a)

\section{Constructed Wetland Subsystem}

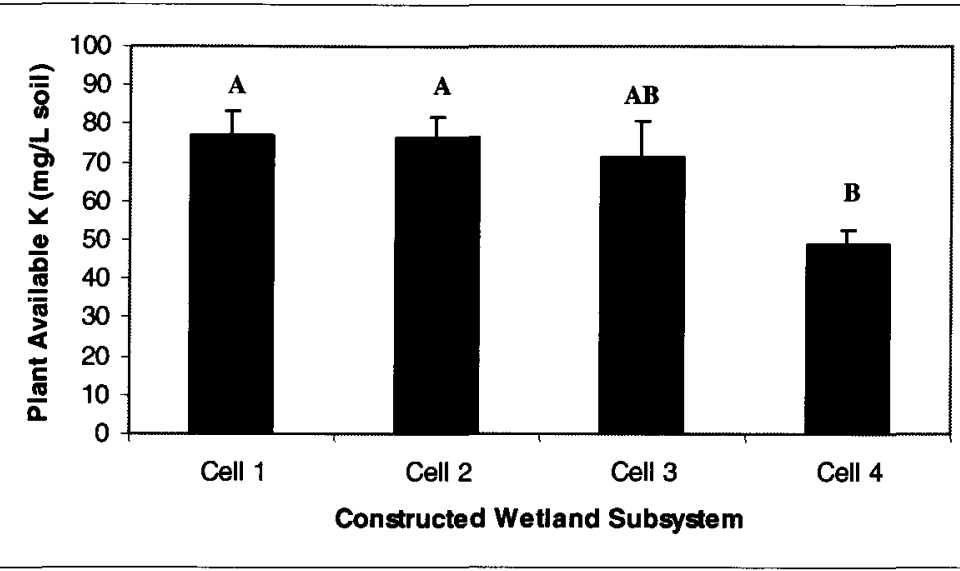

(b)

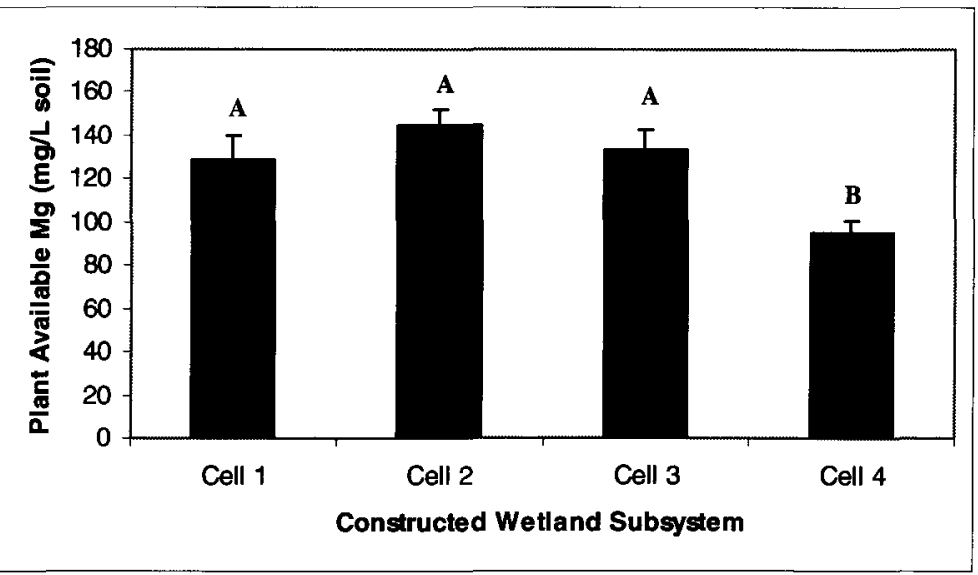

Figure 10. Mean values for plant available (a) $\mathrm{P}$, (b) $\mathrm{K}$, and (c) Mg observed in soil samples collected from each of the four wetland cells at the Markham BMP site in July 2007. Error bars represent the standard error of the mean. Sample size was $n=6$ for Cell 1 and Cell 3 was and $n=12$ for Cell 2 and Cell 4 . Differences between means with the same letters are not statistically significant (ANOVA, $P<0.05$; Kruskal Wallis Test, $P<0.05$ ). 
Plant available $\mathrm{K}$ values suggest that Cell 4 had lower amounts of $\mathrm{K}$ compared to all the other cells in the wetland complex (Figure 10b). An analysis of variance (ANOVA) revealed that there were statistically significant differences in the values between cells $\left(F_{0.05,3,32}=6.363\right.$, $P=0.002$ ). In particular, Cell 4 contained significantly lower concentrations compared to Cell 1 (Tukey HSD Test, $P<0.05$ ) and Cell 2 (Tukey HSD Test, $P<0.05$ ).

Plant available $\mathrm{Mg}$ values suggest that Cell 4 had lower amounts of $\mathrm{Mg}$ compared to all the other cells in the wetland complex (Figure 10c). Kruskal Wallis Tests revealed that there were statistically significant differences in the values between cells $\left(X_{0.05,3}^{2}=18.857, P<0.001\right)$. Specifically, Cell 4 contained significantly lower concentrations of $\mathrm{Mg}$ compared to Cell 1 (Mann Whitney Test, $P=0.003$ ), Cell 2 (Mann Whitney Test, $P<0.0083$ ) and Cell 3 (Mann Whitney Test, $P=0.005$ ).

Overall, there were no consistent trends observed when examining soil chemistry measurements in each cell of the constructed wetland complex (Figure 9 and 10). Furthermore, despite the significant differences in soil chemistry variables for Cell 4 , vegetation composition and abundance were reasonably consistent in all cells of the wetland complex.

\subsubsection{Potential Influences of Soil Chemistry Variables on Community Composition}

The assessment of soil chemistry variables and their association with the presence of the wetland plant species identified during vegetation surveys, involved an evaluation of the correlations between these variables and species abundance.

\subsubsection{Relationships between Soil Chemistry Variables and Individual Plant Species within the Wetland Complex}

T. angustifolia, $P$. arundinacea, S. tabernaemontani, and T. latifolia were the individual plant species identified through vegetation surveys of the wetland complex. As discussed in 
section 2.4 , only two subplots contained S. tabernaemontani; as a result, the sample size was too small for any correlation analysis to be conducted on this species. Therefore, correlation analysis was conducted for soil chemistry variables and T. angustifolia, $P$. arundinacea, and $T$. latifolia using species abundance measures of stem density and biomass.

\section{Correlation Analysis Using Stem Density}

There were no significant relationships observed in a correlation analysis between the soil chemistry measurements for $\mathrm{NH}_{4}-\mathrm{N}, \mathrm{NO}_{3}-\mathrm{N}$, soil organic matter, and $\mathrm{pH}$, and stem density measurements for T. angustifolia, P. arundinacea, and T. latifolia (Table 2 and Figure 11).

Table 2: Correlation coefficient (r) values for relationships between Typha angustifolia, Phalaris arundinacea, and Typha latifolia stem density and soil characteristics such as $\mathrm{NH}_{4}-\mathrm{N}, \mathrm{NO}_{3}-\mathrm{N}$, soil organic matter, and soil pH. None of these correlations was statistically significant $(P>0.05)$ and therefore there were no systematic associations between the soil chemistry variables and plant stem density.

\begin{tabular}{|l|l|c|c|c|c|}
\hline \multicolumn{2}{|c|}{ Species } & $\mathbf{N H}_{\mathbf{4}}-\mathbf{N}$ & $\mathbf{N O}_{\mathbf{3}}-\mathbf{N}$ & Soil Organic Matter & Soil pH \\
\hline Typha angustifolia & $\mathrm{n}=36$ & 0.2777 & 0.1269 & 0.1285 & 0.0877 \\
\hline Phalaris arundinacea & $\mathrm{n}=8$ & 0.4877 & 0.5134 & 0.2587 & 0.1910 \\
\hline Typha latifolia & $\mathrm{n}=26$ & 0.3511 & 0.1145 & 0.2328 & 0.3030 \\
\hline
\end{tabular}

In terms of plant available nutrients, there also were no significant relationships observed in a correlation analysis between the values of plant available $\mathrm{P}, \mathrm{K}$, and $\mathrm{Mg}$ within the soil, and stem density values for T. angustifolia, P. arundinacea, and T. latifolia (Table 3 and Figure 12).

Table 3: Correlation coefficient (r) values for relationships between Typha angustifolia, Phalaris arundinacea, and Typha latifolia stem density and soil characteristics such as plant available $\mathbf{P}, \mathrm{K}$, and $\mathrm{Mg}$. None of these correlations was statistically significant $(P>0.05)$ and therefore there were no systematic associations between plant available nutrients and plant stem density.

\begin{tabular}{|l|l|c|c|c|}
\hline \multicolumn{2}{|c|}{ Species } & Plant available P & Plant available K & Plant available Mg \\
\hline Typha angustifolia & $\mathrm{n}=36$ & 0.2759 & 0.0656 & 0.0141 \\
\hline Phalaris arundinacea & $\mathrm{n}=8$ & 0.3263 & 0.1584 & 0.3111 \\
\hline Typha latifolia & $\mathrm{n}=26$ & 0.2629 & 0.1905 & 0.1245 \\
\hline
\end{tabular}


(a)

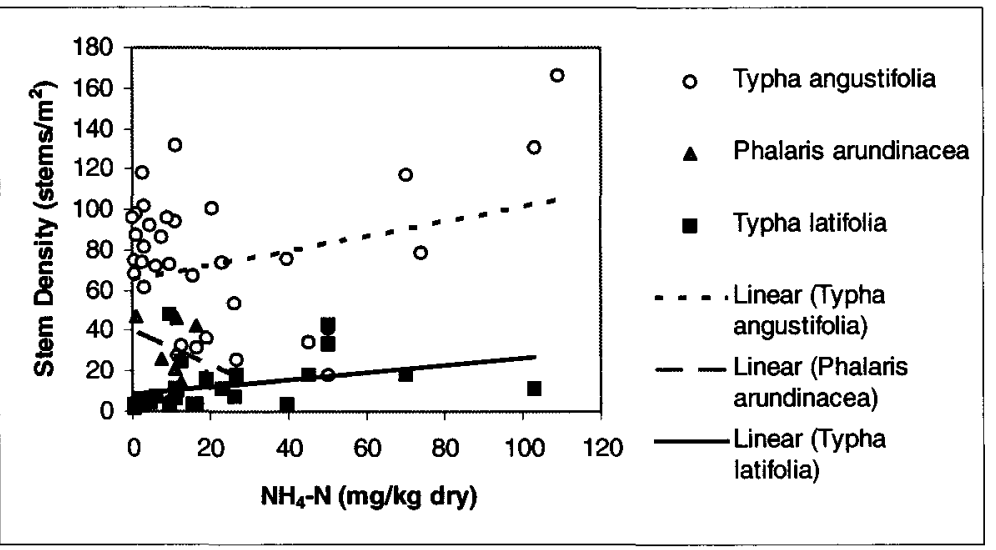

(c)

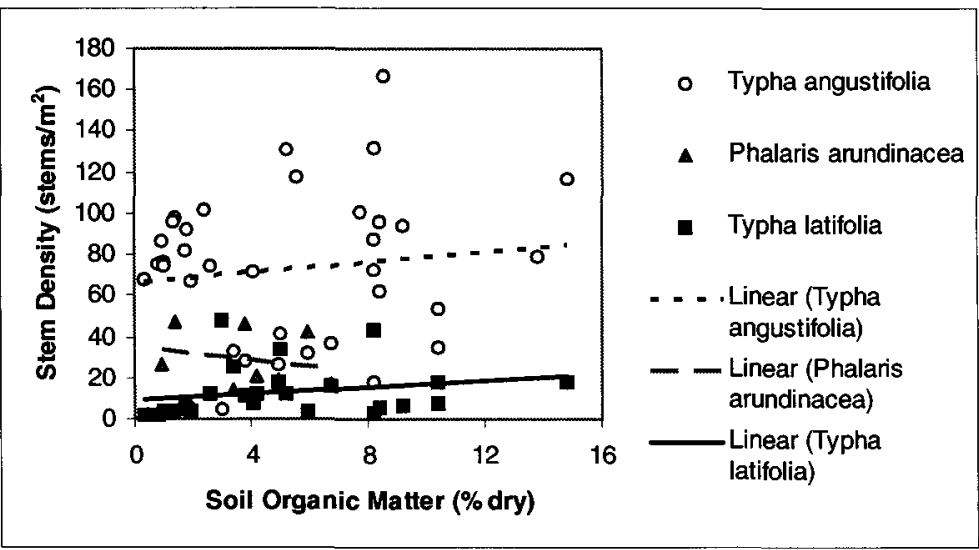

(d)

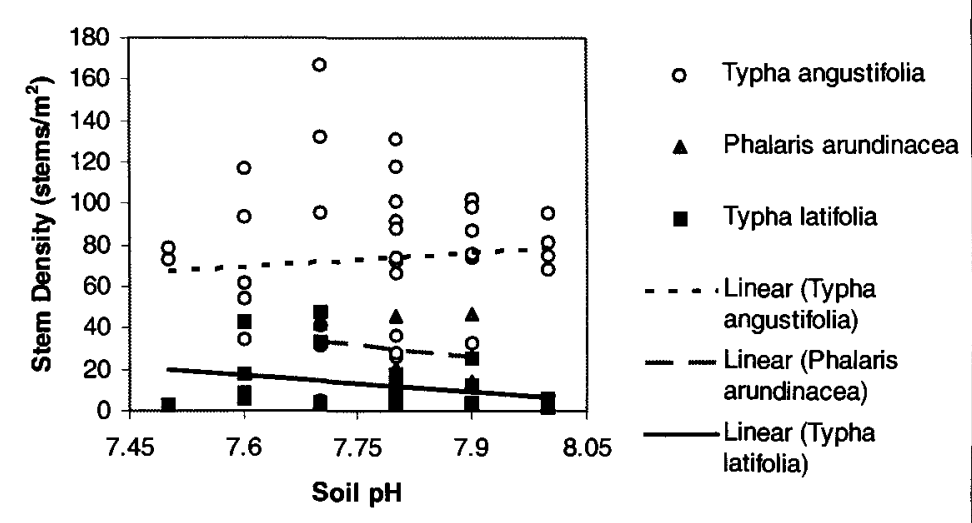

Figure 11. Relationships between Typha angustifolia, Phalaris arundinacea, and Typha latifolia stem density and soil characteristics such as (a) $\mathrm{NH}_{4}-\mathrm{N}_{\text {, }}$ (b) $\mathrm{NO}_{3}-\mathrm{N}$, (c) soil organic matter, and (d) soil $\mathrm{pH}$. Open circles represent the stem density of Typha angustifolia (n=36), outlined triangles represent the stem density of Phalaris arundinacea $(\mathrm{n}=8)$, and filled squares represent the stem density of Typha latifolia $(\mathrm{n}=26)$. The regression lines for Typha angustifolia, Phalaris arundinacea, and Typha latifolia are represented by a dotted line, a dashed line, and solid line respectively. Correlation coefficients (r) for each regression line can be found in the text. There were no significant correlations found for any of these variables and stem density. 
(a)

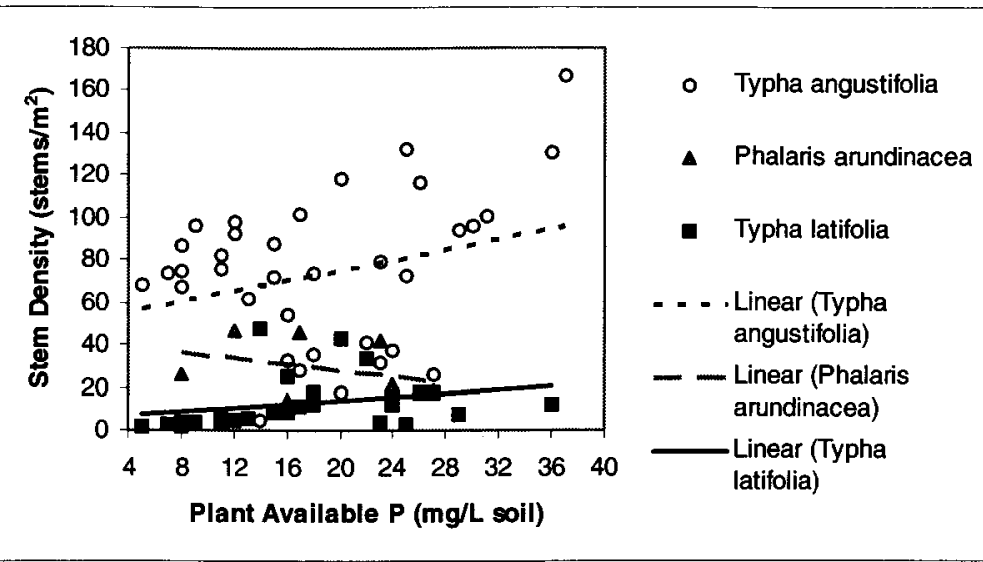

(b)

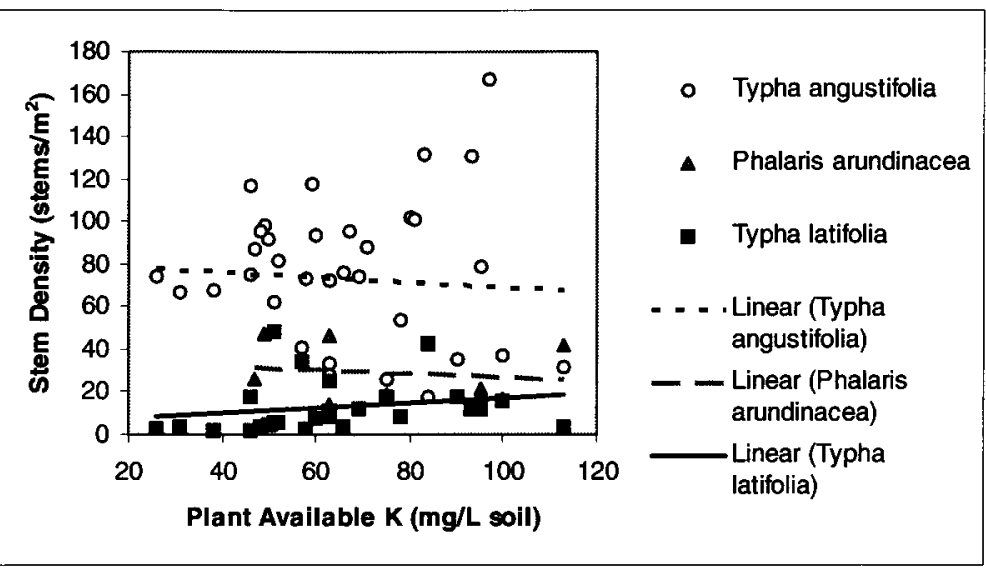

(c)

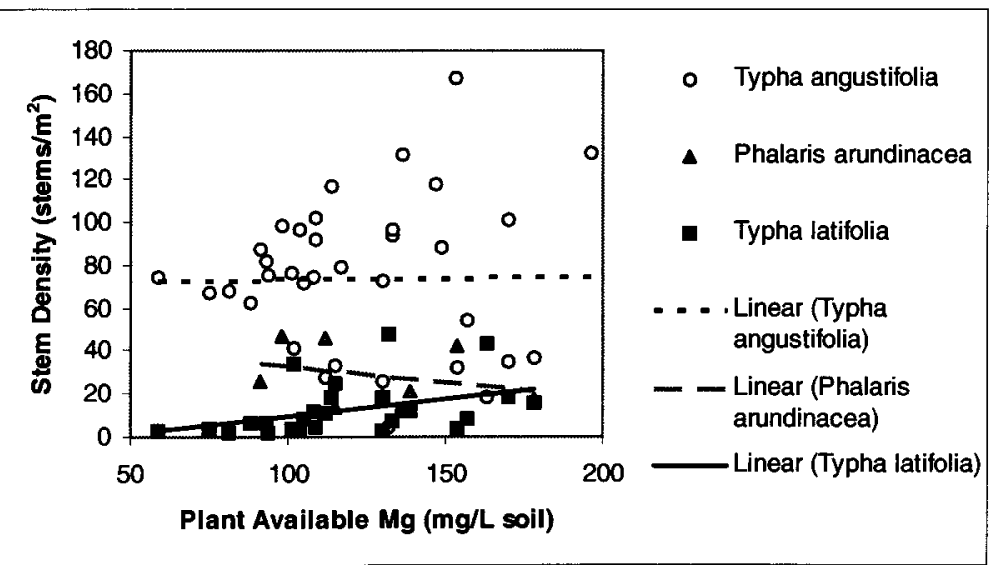

Figure 12. Relationships between Typha angustifolia, Phalaris arundinacea, and Typha latifolia stem density and soil characteristics such as plant available (a) $\mathbf{P},(\mathbf{b}) \mathrm{K}$, and (c) $\mathbf{M g}$. Open circles represent the stem density of Typha angustifolia $(\mathrm{n}=36)$, outlined triangles represent the stem density of Phalaris arundinacea $(\mathrm{n}=8)$, and filled squares represent the stem density of Typha latifolia $(\mathrm{n}=26)$. The regression lines for Typha angustifolia, Phalaris arundinacea, and Typha latifolia are represented by a dotted line, a dashed line, and solid line respectively. Correlation coefficients ( $r$ ) for each relationship can be found in the text. There were no significant correlations found for any of these variables and stem density. 


\section{Correlation Analysis Using Biomass}

There was only one significant relationship observed in a correlation analysis between the soil chemistry measurements for $\mathrm{NH}_{4}-\mathrm{N}, \mathrm{NO}_{3}-\mathrm{N}$, soil organic matter, and $\mathrm{pH}$, and biomass measurements for T. angustifolia, P. arundinacea, and T. latifolia (Table 4 and Figure 13). A statistically significant association was observed between $\mathrm{NH}_{4}-\mathrm{N}$ concentrations and $T$. latifolia biomass $\left(r_{0.05,25}=0.4680, P<0.02\right)$. The direction of the correlation was positive, implying that $T$. latifolia biomass increases with increasing $\mathrm{NH}_{4}-\mathrm{N}$ concentrations in the soil (Figure 13a).

Table 4: Correlation coefficient (r) values for relationships between Typha angustifolia, Phalaris arundinacea, and Typha latifolia biomass and soil characteristics such as $\mathrm{NH}_{4}-\mathrm{N}, \mathrm{NO}_{3}-\mathrm{N}$, soil organic matter, and soil pH. Significant correlations occurred between Typha latifolia biomass and $\mathrm{NH}_{4}-\mathrm{N}\left(r_{0.05 .25}=0.4680, P<0.02\right)$. All other correlations were not statistically significant $(P>0.05)$ and therefore there were no systematic associations between these soil characteristics and plant biomass.

\begin{tabular}{|l|l|c|c|c|c|}
\hline \multicolumn{2}{|c|}{ Species } & $\mathbf{N H}_{\mathbf{4}}-\mathbf{N}$ & $\mathbf{N O}_{\mathbf{3}}-\mathbf{N}$ & Soil Organic Matter & Soil pH \\
\hline Typha angustifolia & $\mathrm{n}=36$ & 0.0959 & 0.0970 & 0.1212 & 0.0316 \\
\hline Phalaris arundinacea & $\mathrm{n}=8$ & 0.4601 & 0.1261 & 0.3184 & 0.6598 \\
\hline Typha latifolia & $\mathrm{n}=26$ & $0.4680^{*}$ & 0.2670 & 0.3803 & 0.3384 \\
\hline
\end{tabular}

In terms of plant available nutrients, there were two significant relationships observed in a correlation analysis between the values of plant available $\mathrm{P}, \mathrm{K}$, and $\mathrm{Mg}$ within the soil, and biomass values for T. angustifolia, P. arundinacea, and T. latifolia (Table 5 and Figure 14). A statistically significant association was observed between plant available $\mathrm{P}$ concentrations and $T$. latifolia biomass $\left(r_{0.05,25}=0.3848, P<0.05\right)$. The direction of the correlation was positive, implying that $T$. latifolia biomass increases with increasing plant available $\mathrm{P}$ concentrations in the soil (Figure 14a). Also, a statistically significant association was observed between plant available $\mathrm{Mg}$ concentrations and $T$. latifolia biomass $\left(r_{0.05,25}=0.5061, P<0.01\right)$. The direction of 
(a)

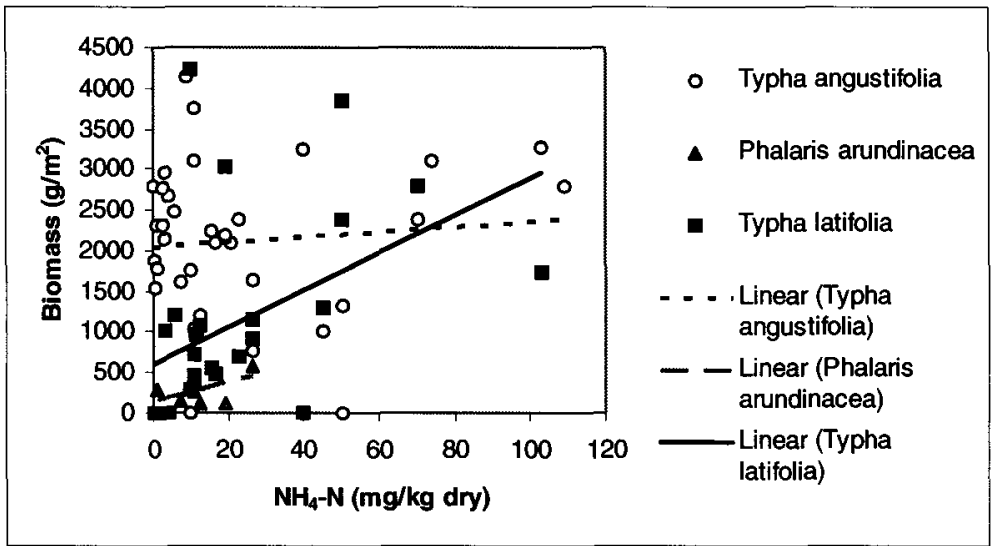

(b)

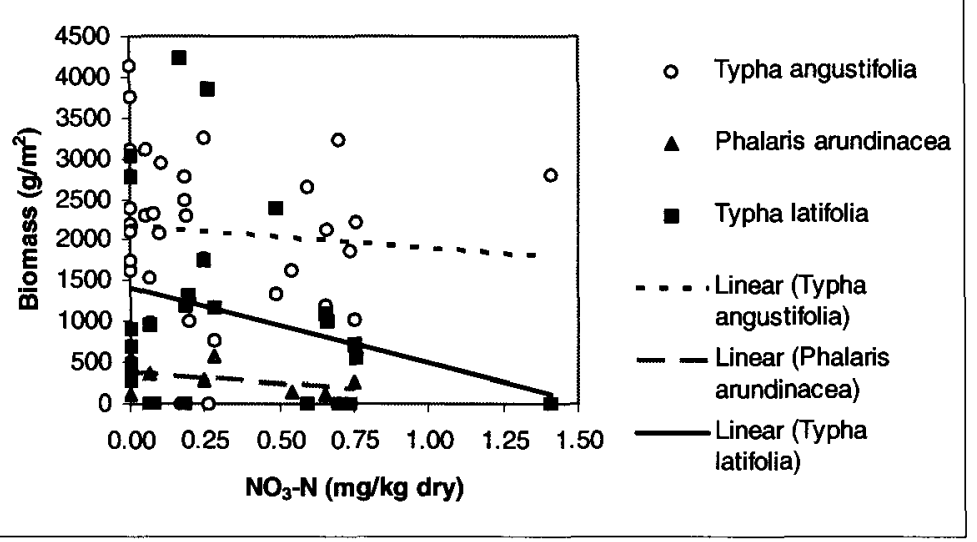

(c)

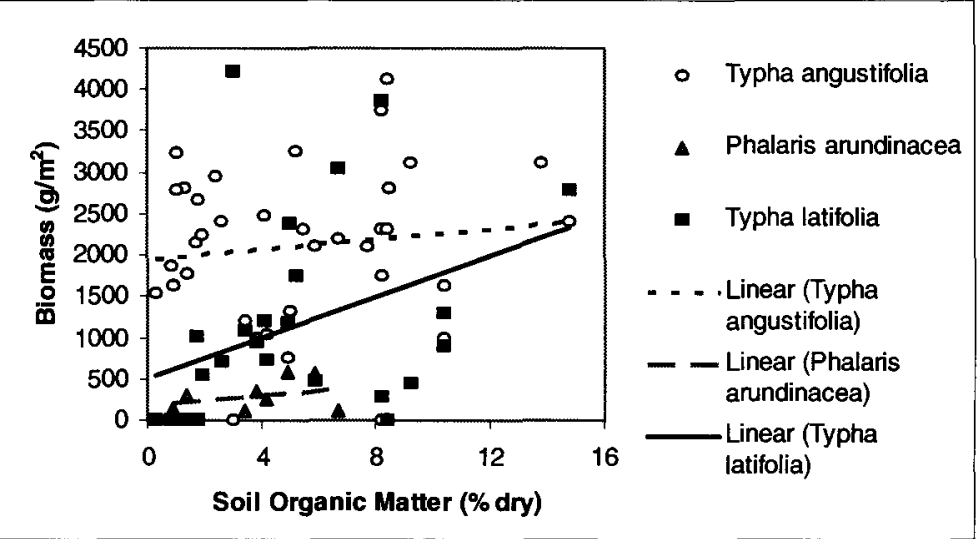

(d)

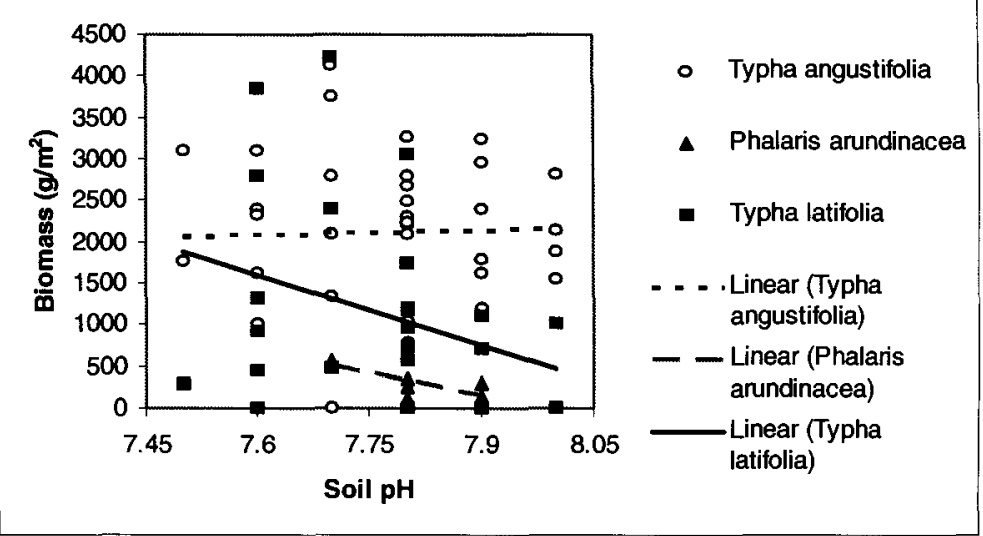

Figure 13. Relationships between Typha angustifolia, Phalaris arundinacea, and Typha latifolia biomass and soil characteristics such as (a) $\mathrm{NH}_{4}-\mathrm{N}$, (b) $\mathrm{NO}_{3}-\mathrm{N}$, (c) soil organic matter, and (d) soil pH. Open circles represent the biomass of Typha angustifolia $(\mathrm{n}=36$ ), outlined triangles represent the biomass of Phalaris arundinacea $(\mathrm{n}=8)$, and filled squares represent the biomass of Typha latifolia $(\mathrm{n}=26)$. The regression lines for Typha angustifolia, Phalaris

arundinacea, and Typha latifolia are represented by a dotted line, a dashed line, and solid line respectively. Correlation coefficients ( $r$ ) for each relationship are can be found in the text. Significant correlations occurred between Typha latifolia biomass and (a) $\mathrm{NH}_{4}-\mathrm{N}_{(}\left(r_{0.05,25}=0.4680, P<0.02\right)$. 


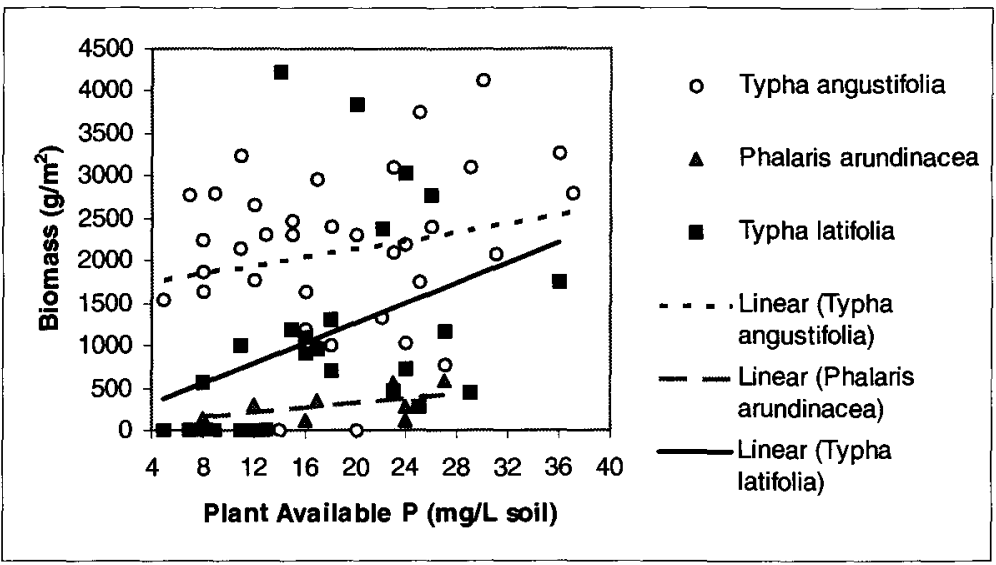

(b)

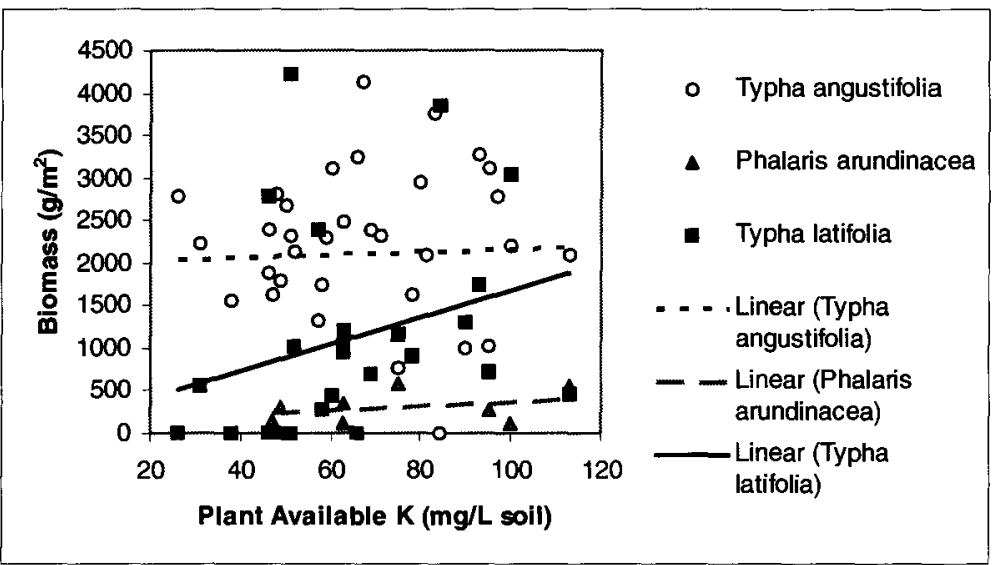

(c)

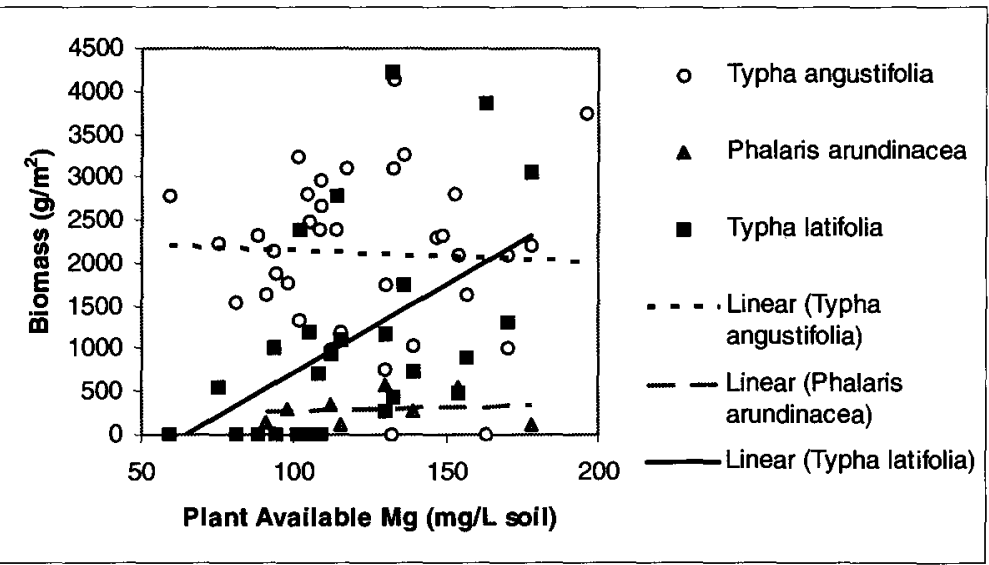

Figure 14. Relationships between Typha angustifolia, Phalaris arundinacea, and Typha latifolia biomass and soil characteristics such as plant available (a) $\mathbf{P},(\mathbf{b}) \mathbf{K}$, and (c) $\mathbf{M g}$. Open circles represent the biomass of Typha angustifolia $(\mathrm{n}=36)$, outlined triangles represent the biomass of Phalaris arundinacea $(\mathrm{n}=8)$, and filled squares represent the biomass of Typha latifolia $(\mathrm{n}=26)$. The regression lines for Typha angustifolia, Phalaris arundinacea, and Typh latifolia are represented by a dotted line, a dashed line, and solid line respectively. Correlation coefficients (r) for each relationship can be found in the text. Significant correlations occurred between Typha latifolia biomass and plant available (a) $\mathrm{P}\left(r_{0.05,25}=0.3848, P<0.05\right)$, and (c) $\mathrm{Mg}\left(r_{0.05,25}=5061, P<0.01\right)$. 
the correlation was positive, implying that $T$. latifolia biomass increases with increasing plant available $\mathrm{Mg}$ concentrations in the soil (Figure 14c).

Table 5: Correlation coefficient (r) values for relationships between Typha angustifolia, Phalaris arundinacea, and Typha latifolia biomass and soil characteristics such as plant available $\mathbf{P}, \mathrm{K}$, and Mg. Significant correlations occurred between Typha latifolia biomass and plant available $\mathrm{P}\left(r_{0.05,25}=0.3848, P<0.05\right)$, and $\mathrm{Mg}$ $\left(r_{0.05,25}=5061, P<0.01\right)$. All other correlations were not statistically significant $(P>0.05)$ and therefore there were no systematic associations between these soil characteristics and plant biomass.

\begin{tabular}{|l|l|c|c|c|}
\hline \multicolumn{2}{|c|}{ Species } & Plant available P & Plant available K & Plant available Mg \\
\hline Typha angustifolia & $\mathrm{n}=36$ & 0.2149 & 0.0374 & 0.0447 \\
\hline Phalaris arundinacea & $\mathrm{n}=8$ & 0.5062 & 0.2804 & 0.1338 \\
\hline Typha latifolia & $\mathrm{n}=26$ & $0.3848^{*}$ & 0.3320 & $0.5061^{*}$ \\
\hline
\end{tabular}

*statistically significant $(P<0.05)$

\subsubsection{Relationships between Soil Chemistry Variables and Invasive and Native Plant Species within the Wetland Complex}

Invasive species composition included $T$. angustifolia and $P$. arundinacea, and native species composition included T. latifolia and S. tabernaemontani. Correlation analysis was conducted for soil chemistry variables and invasive species and native species using the abundance measures of stem density and biomass

\section{Correlation Analysis Using Stem Density}

There was only one significant relationship observed in a correlation analysis between the soil chemistry measurements for $\mathrm{NH}_{4}-\mathrm{N}, \mathrm{NO}_{3}-\mathrm{N}$, soil organic matter, and $\mathrm{pH}$, and stem density measurements for invasive and native plant species (Table 6 and Figure 15). A statistically significant association was observed between $\mathrm{NH}_{4}-\mathrm{N}$ concentrations and invasive plant stem density $\left(r_{0.05,43}=0.2950, P<0.05\right)$. The direction of the correlation was positive, implying that invasive plant stem density increases with increasing $\mathrm{NH}_{4}-\mathrm{N}$ concentrations in the soil (Figure $15 a)$. 
(a)

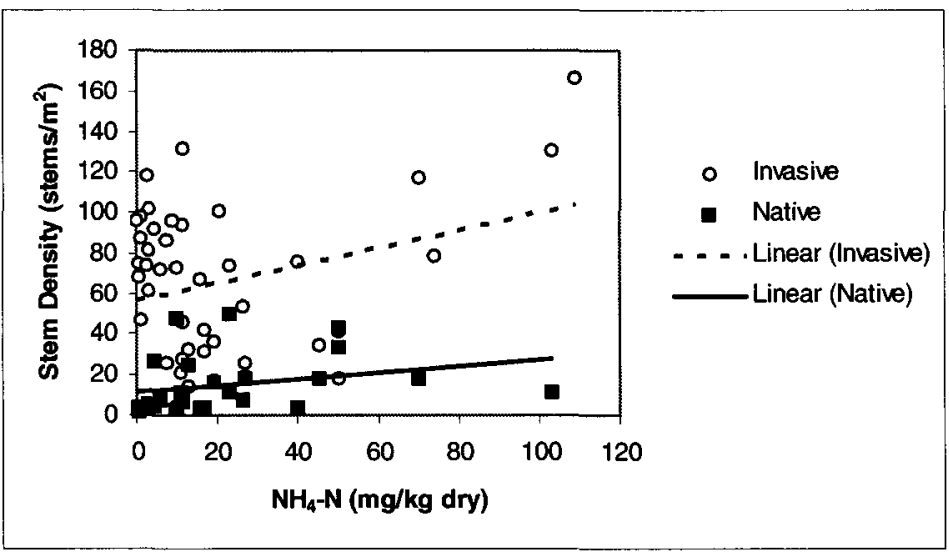

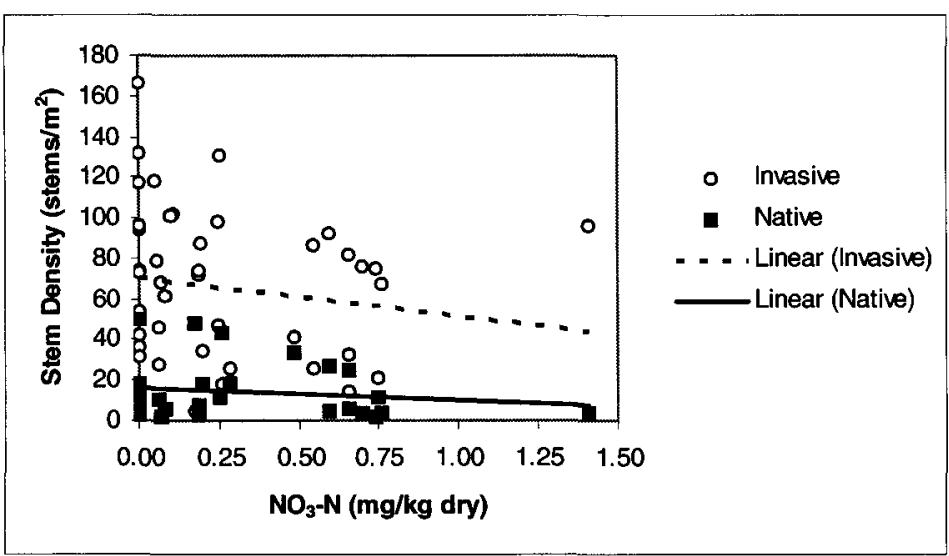

(c)

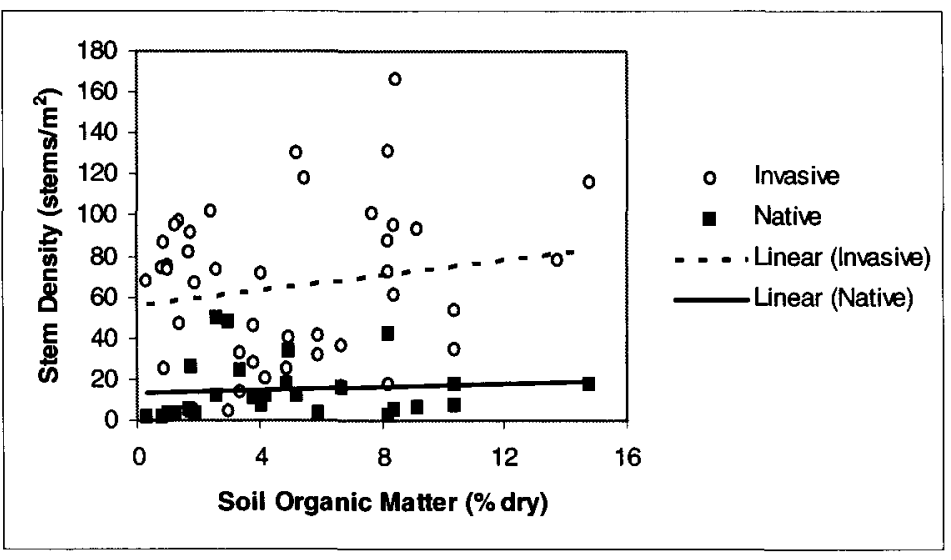

(d)

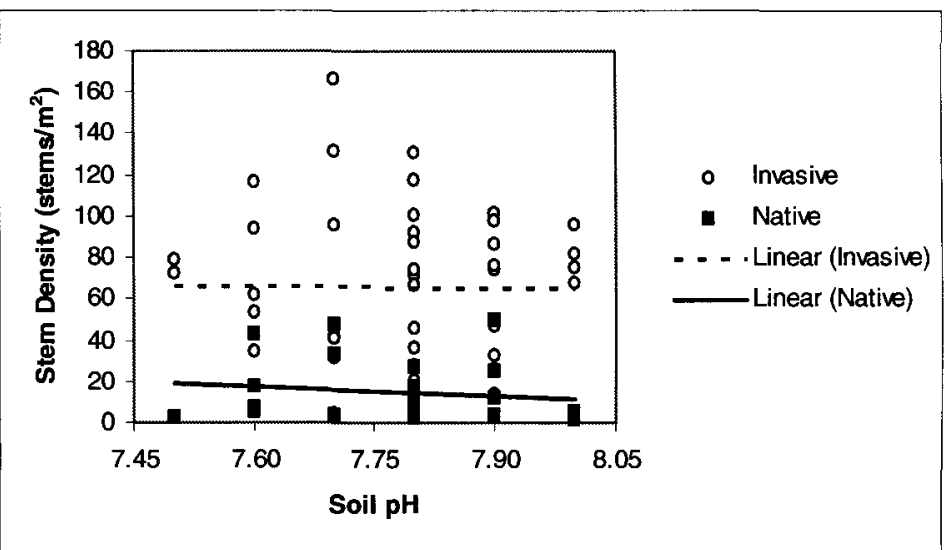

Figure 15. Relationships between invasive and native species stem density and soil characteristics such as (a) $\mathrm{NH}_{4}-\mathrm{N}$, (b) $\mathrm{NO}_{3}-\mathrm{N}$, (c) soil organic matter, and (d) soil pH. Open circles represent the stem density of invasive species $(n=44)$ and filled squares represent the stem density of native species $(\mathrm{n}=28)$. The regression lines for invasive and native species are represented by a dotted line and solid line respectively. Correlation coefficients $(r)$ for each relationship can be found in the text. Significant correlations occurred between invasive species stem density and (a) $\mathrm{NH}_{4}-\mathrm{N}\left(r_{0.05,43}=0.2950, P<0.05\right)$. 
Table 6: Correlation coefficient ( $r$ ) values for relationships between invasive and native species stem density and soil characteristics such as $\mathrm{NH}_{\mathbf{4}}-\mathrm{N}$, $\mathrm{NO}_{3}-\mathrm{N}$, soil organic matter, and soil pH. Significant correlations occurred between invasive species stem density and $\mathrm{NH}_{4}-\mathrm{N}\left(r_{0.05,43}=0.2950, P<0.05\right)$. All other correlations were not statistically significant $(P>0.05)$ and therefore there were no systematic associations between these soil characteristics and plant stem density.

\begin{tabular}{|l|l|l|l|c|c|}
\hline \multicolumn{2}{|c|}{ Species } & $\mathbf{N H}_{4}-\mathbf{N}$ & $\mathbf{N O}_{3}-\mathbf{N}$ & Soil Organic Matter & Soil pH \\
\hline Invasives & $\mathrm{n}=44$ & $0.2950^{*}$ & 0.1568 & 0.1732 & 0.0045 \\
\hline Natives & $\mathrm{n}=28$ & 0.2748 & 0.1559 & 0.1049 & 0.1637 \\
\hline
\end{tabular}

*statistically significant $(P<0.05)$

In terms of plant available nutrients, there were no significant relationships observed in a correlation analysis between the values of plant available $\mathrm{P}, \mathrm{K}$, and $\mathrm{Mg}$ within the soil, and stem density values for invasive and native species (Table 7 and Figure 16).

Table 7: Correlation coefficient ( $r$ ) values for relationships between invasive and native species stem density and soil characteristics such as plant available $\mathbf{P}, \mathrm{K}$, and $\mathrm{Mg}$. None of these correlations was statistically significant $(P>0.05)$ and therefore there were no systematic associations between these soil characteristics and plant stem density.

\begin{tabular}{|l|l|c|c|c|}
\hline \multicolumn{2}{|c|}{ Species } & Plant available P & Plant available K & Plant available Mg \\
\hline Invasives & $\mathrm{n}=44$ & 0.2066 & 0.1360 & 0.0265 \\
\hline Natives & $\mathrm{n}=28$ & 0.2037 & 0.1600 & 0.2879 \\
\hline
\end{tabular}

\section{Correlation Analysis Using Biomass}

There were two significant relationships observed in a correlation analysis between the soil chemistry measurements for $\mathrm{NH}_{4}-\mathrm{N}, \mathrm{NO}_{3}-\mathrm{N}$, soil organic matter, and $\mathrm{pH}$, and biomass measurements for invasive and native plant species (Table 8 and Figure 17). A statistically significant association was observed between $\mathrm{NH}_{4}-\mathrm{N}$ concentrations and native plant biomass $\left(r_{0.05,27}=0.4717, P<0.01\right)$. The direction of the correlation was positive, implying that native plant biomass increases with increasing $\mathrm{NH}_{4}-\mathrm{N}$ concentrations in the soil (Figure 17a). Also, a statistically significant association was observed between soil organic matter and native plant 
(a)

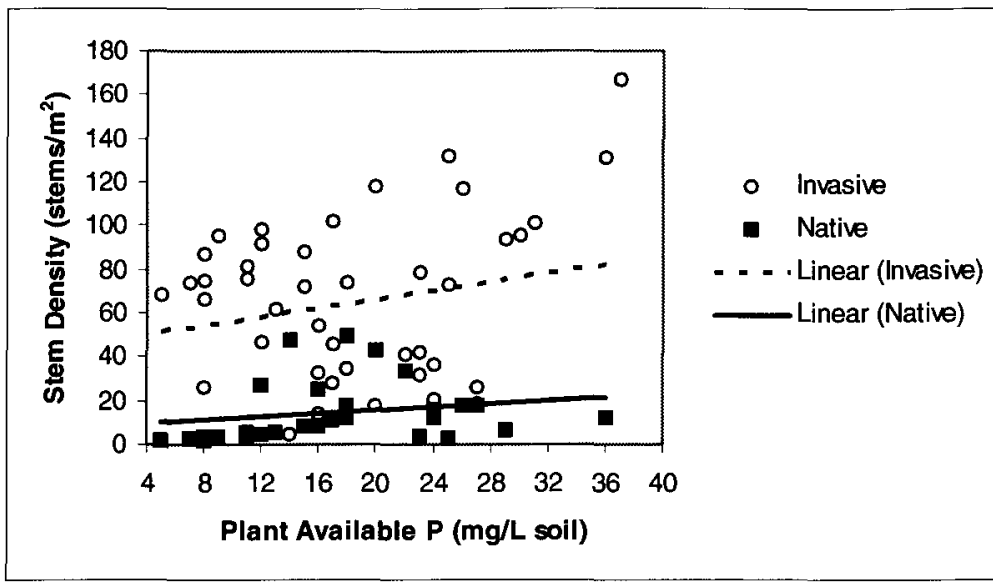

(b)

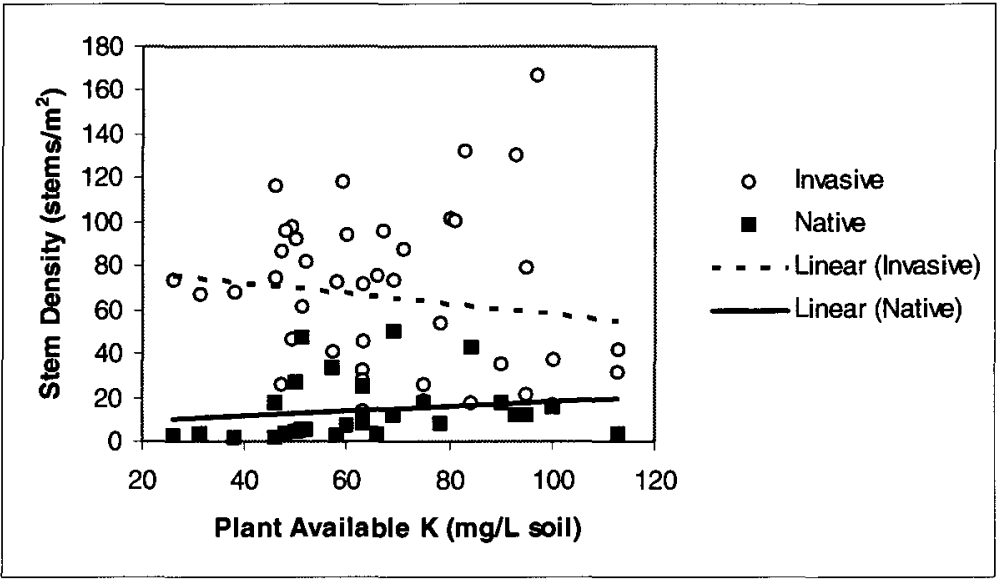

(c)

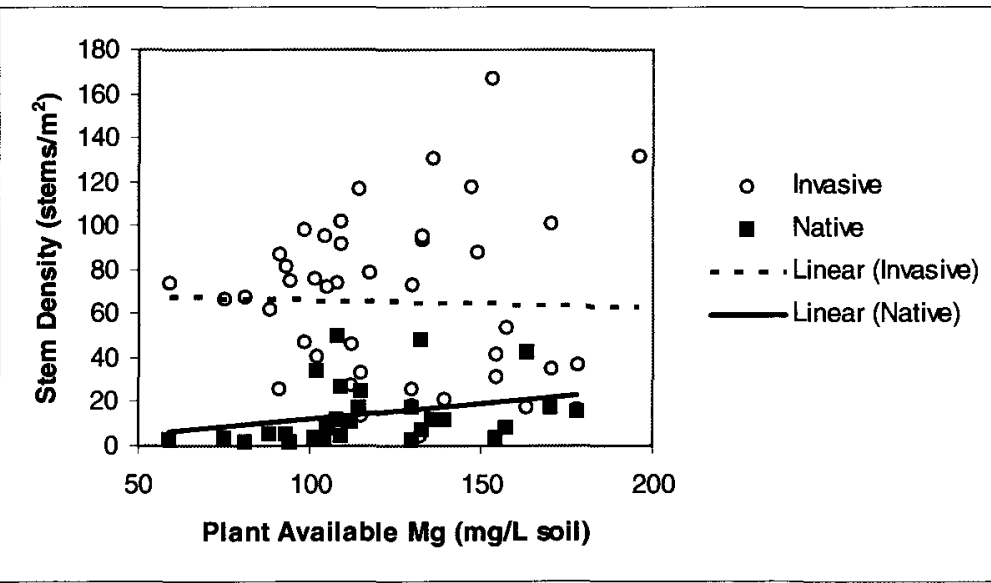

Figure 16. Relationships between invasive and native species stem density and soil characteristics such as plant available (a) $\mathbf{P}$, (b) $\mathbf{K}$, and (c) Mg. Open circles represent the stem density of invasive species ( $\mathrm{n}=44$ ) and filled squares represent the stem density of native species $(n=28)$. The regression lines for invasive and native species are represented by a dotted line and solid line respectively. Correlation coefficients (r) for each relationship can be found in the text. There were no significant correlations found for any of these variables and stem density. 
(a)

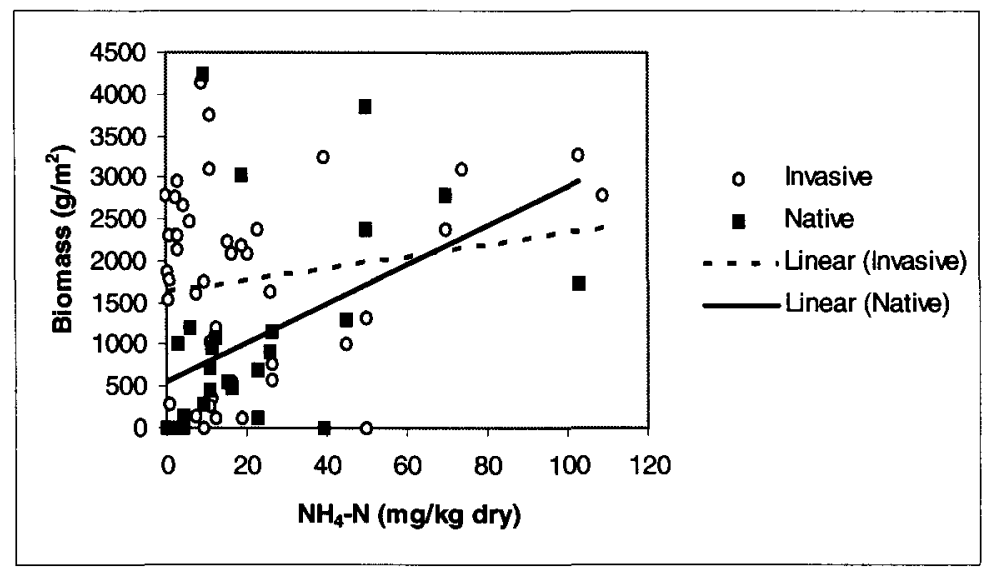

(c)

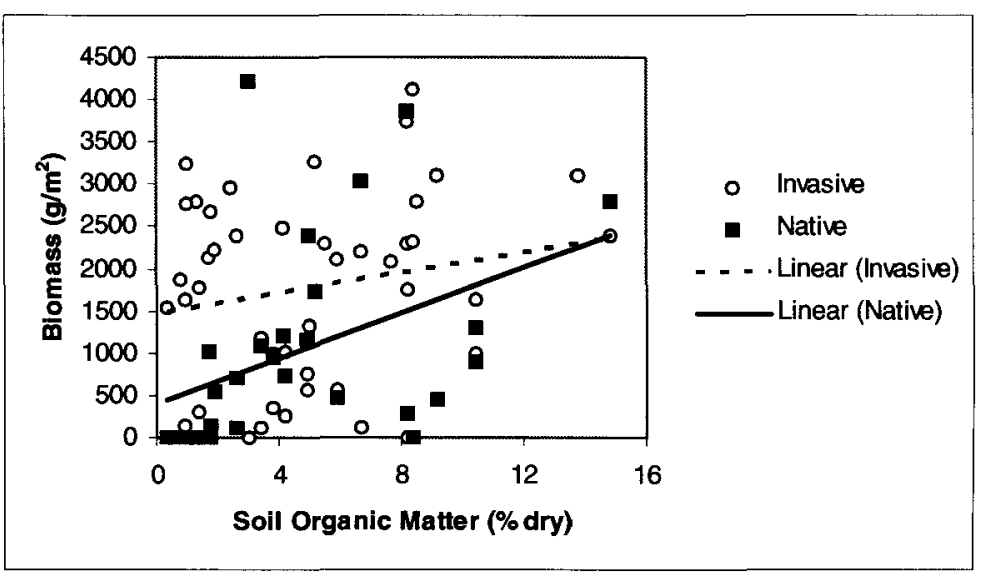

(d)

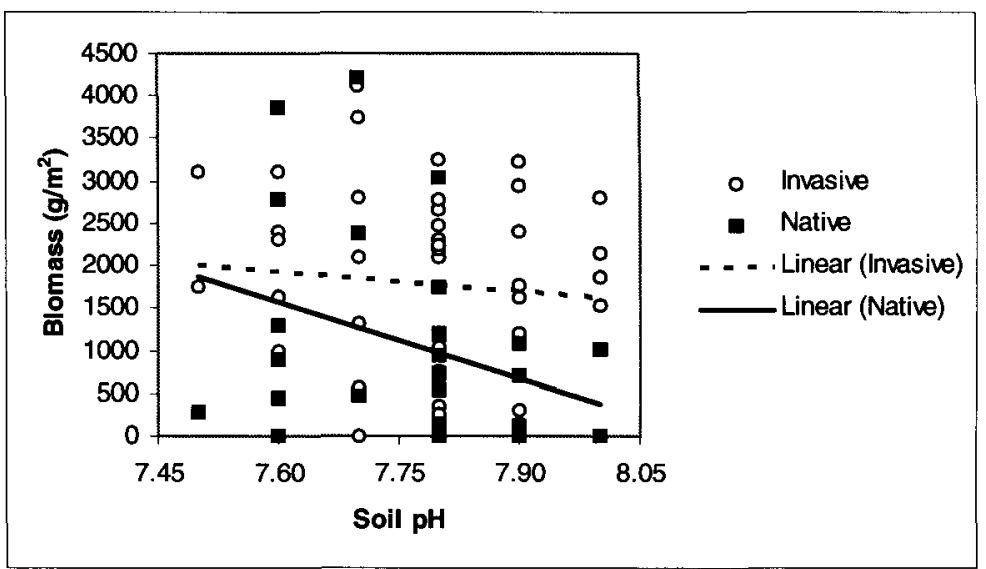

Figure 17. Relationships between invasive and native species biomass and soil characteristics such as (a) $\mathbf{N H}_{4}-\mathbf{N}$, (b) $\mathbf{N O}_{3}-\mathbf{N}$, (c) soil organic matter, and (d) soil pH. Open circles represent the biomass of invasive species $(n=44)$ and filled squares represent the biomass of native species ( $n=28)$. The regression lines for invasive and native species are represented by a dotted line and solid line respectively. Correlation coefficients (r) for each relationship can be found in the text. Significant correlations occurred between native species biomass and (a) $\mathrm{NH}_{4}-\mathrm{N}\left(r_{0.05,27}=0.4717, P<0.01\right)$, and (c) soil organic matter $\left(r_{0.05,27}=0.4063\right.$, $P<0.05)$. 
biomass $\left(r_{0.05,27}=0.4063, P<0.05\right)$. The direction of the correlation was positive, implying that native plant biomass increases with increasing soil organic matter (Figure 17c).

Table 8: Correlation coefficient ( $r$ ) values for relationships between invasive and native species biomass and soil characteristics such as $\mathbf{N H}_{\mathbf{4}}-\mathbf{N}$, $\mathbf{N O}_{3}-\mathbf{N}$, soil organic matter, and soil pH. Significant correlations occurred between native species biomass and $\mathrm{NH}_{4}-\mathrm{N}\left(r_{0.05,27}=0.4717, P<0.01\right)$, and soil organic matter $\left(r_{0.05,27}=0.4063\right.$, $P<0.05)$. All of the other correlations were not statistically significant $(P>0.05)$ and therefore there were no systematic associations between these soil characteristics and plant biomass.

\begin{tabular}{|l|l|l|l|c|c|}
\hline \multicolumn{2}{|c|}{ Species } & $\mathbf{N H}_{4}-\mathbf{N}$ & $\mathbf{N O}_{3}-\mathbf{N}$ & Soil Organic Matter & Soil $\mathbf{~ p H}$ \\
\hline Invasives & $\mathrm{n}=44$ & 0.1655 & 0.1145 & 0.1967 & 0.0872 \\
\hline Natives & $\mathrm{n}=28$ & $0.4717^{*}$ & 0.2484 & $0.4063^{*}$ & 0.3564 \\
\hline
\end{tabular}

*statistically significant $(P<0.05)$

In terms of plant available nutrients, there were two significant relationships observed in a correlation analysis between the values of plant available $\mathrm{P}, \mathrm{K}$, and $\mathrm{Mg}$ within the soil, and biomass values for invasive and native plant species (Table 9 and Figure 18). A statistically significant association was observed between plant available $\mathrm{P}$ concentrations and native plant biomass $\left(r_{0.05,27}=0.3903, P<0.05\right)$. The direction of the correlation was positive, implying that native plant biomass increases with increasing plant available $\mathrm{P}$ concentrations in the soil (Figure 18a). Also, a statistically significant association was observed between plant available $\mathrm{Mg}$ concentrations and native plant biomass $\left(r_{0.05,27}=0.5117, P<0.01\right)$. The direction of the correlation was positive, implying that native plant biomass increases with increasing plant available $\mathrm{Mg}$ concentrations in the soil (Figure 18c).

Table 9: Correlation coefficient ( $r$ ) values for relationships between invasive and native species biomass and soil characteristics such as plant available $P, K$, and $M g$. Significant correlations occurred between native species biomass and plant available $\mathrm{P}\left(r_{0.05,27}=0.3903, P<0.05\right)$, and $\mathrm{Mg}\left(r_{0.05,27}=0.5117, P<0.01\right)$. All of the other correlations were not statistically significant $(P>0.05)$ and therefore there were no systematic associations between these soil characteristics and plant biomass.

\begin{tabular}{|l|l|c|c|c|}
\hline \multicolumn{2}{|c|}{ Species } & Plant available P & Plant available K & Plant available Mg \\
\hline Invasives & $\mathrm{n}=44$ & 0.1603 & 0.0693 & 0.0574 \\
\hline Natives & $\mathrm{n}=28$ & $0.3903 *$ & 0.2830 & $0.5117^{*}$ \\
\hline
\end{tabular}


(a)

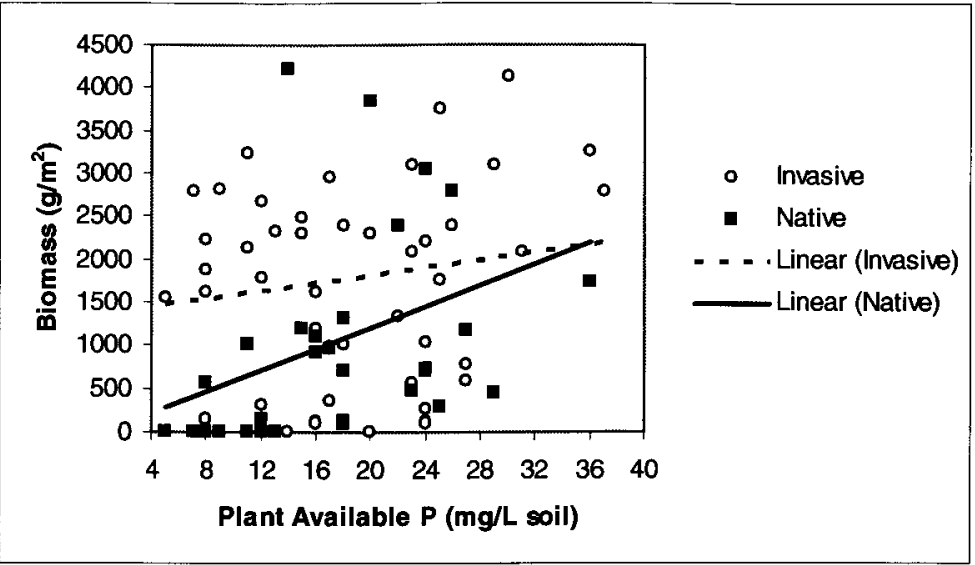

(b)

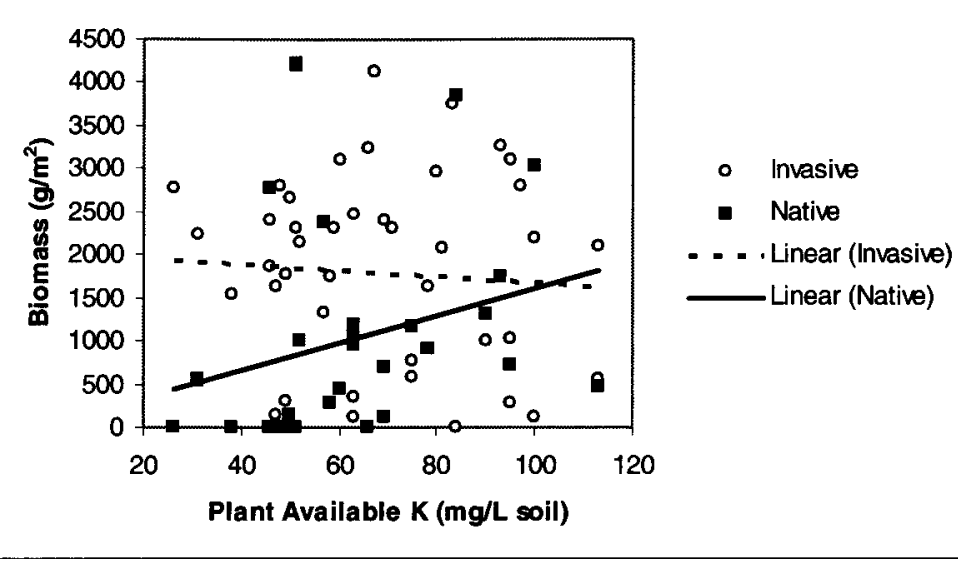

(c)

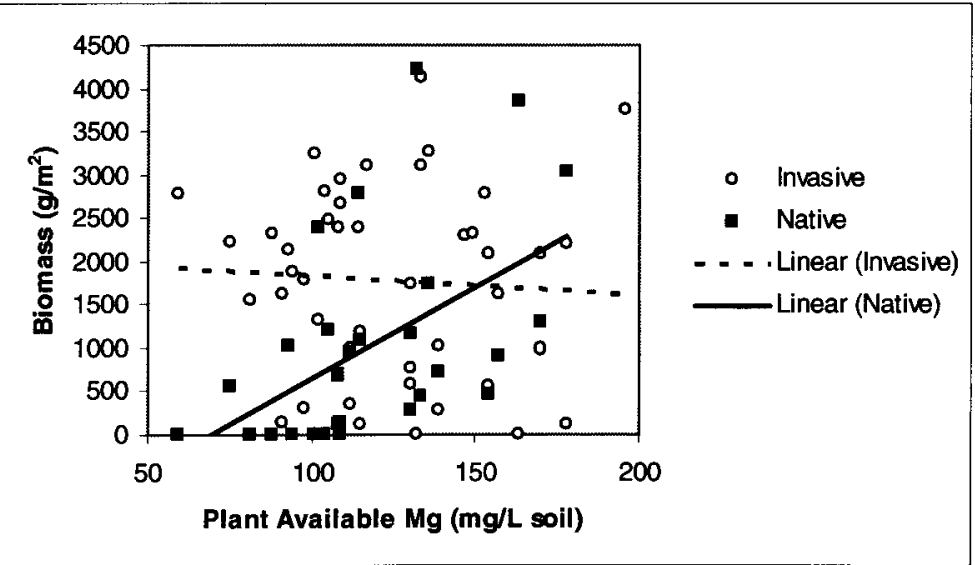

Figure 18. Relationships between invasive and native species biomass and soil characteristics such as plant available (a) $P$, (b) $K$, and (c) $M g$. Open circles represent the biomass of invasive species ( $n=44)$ and filled squares represent the biomass of native species $(n=28)$. The regression lines for invasive and native species are represented by a dotted line and solid line respectively. Correlation coefficients ( $r$ ) for each relationship can be found in the text. Significant correlations occurred between native species biomass and plant available (a) $\mathrm{P}\left(r_{0.05,27}=0.3903, P<0.05\right)$, and (c) $\mathrm{Mg}\left(r_{0.05,27}=0.5117, P<0.01\right)$. 


\subsubsection{Potential Trends in Water Chemistry Variables Between Subsystems of Markham BMP}

Mean TKN, dissolved $\mathrm{P}, \mathrm{Cu}, \mathrm{Zn}$, water $\mathrm{pH}, \mathrm{DO} \%$ saturation, TDS, and salinity measurements for samples collected in Cell 1, Cell 2, Cell 3, and Cell 4 are listed in Table 10. Kennedy and Mayer (2002) suggested that wetland plants remove significant quantities of metals such as $\mathrm{Cu}$ and $\mathrm{Zn}$. However, as indicated in section 3.3, trends for these values could not be determined as these measurements were below detectable limits.

Table 10: Mean \pm 1 SE values for water chemistry variables observed in water samples collected in each subsystem at the Markham BMP site in July 2007.

\begin{tabular}{|c|c|c|c|c|c|c|c|c|c|}
\hline \multicolumn{2}{|c|}{ Subsystem } & $\begin{array}{c}\text { TKN } \\
(\mathbf{m g} / \mathbf{L})\end{array}$ & $\begin{array}{c}\text { Dissolved P } \\
(\mathbf{m g} / \mathbf{L})\end{array}$ & $\begin{array}{c}\mathbf{C u} \\
(\mathbf{m g} / \mathbf{L})\end{array}$ & $\begin{array}{c}\mathbf{Z n} \\
(\mathbf{m g} / \mathbf{L})\end{array}$ & Water pH & $\begin{array}{c}\text { Do \% } \\
\text { saturation }\end{array}$ & TDS (ppm) & $\begin{array}{c}\text { Salinity } \\
\text { (PSU) }\end{array}$ \\
\hline Forebay & $\mathrm{n}=3$ & $1.23 \pm 0.08$ & $<0.05$ & $<0.2$ & $<0.2$ & $8.33 \pm 0.15$ & $91.90 \pm 32.03$ & $218.33 \pm 52.95$ & $0.21 \pm 0.05$ \\
\hline Wet Pond & $\mathrm{n}=3$ & $1.14 \pm 0.04$ & $<0.05$ & $<0.2$ & $<0.2$ & $8.44 \pm 0.31$ & $104.77 \pm 24.08$ & $297.33 \pm 17.37$ & $0.29 \pm 0.02$ \\
\hline Cell 1 & $\mathrm{n}=3$ & $1.33 \pm 0.03$ & $<0.05$ & $<0.2$ & $<0.2$ & $8.02 \pm 0.24$ & $78.53 \pm 16.34$ & $311.33 \pm 17.65$ & $\mathbf{0 . 3 0 \pm 0 . 0 2}$ \\
\hline Cell 2 & $\mathrm{n}=3$ & $1.41 \pm 0.01$ & $<0.05$ & $<0.2$ & $<0.2$ & $7.99 \pm 0.15$ & $81.00 \pm 11.82$ & $309.00 \pm 17.95$ & $\mathbf{0 . 3 0 \pm 0 . 0 2}$ \\
\hline Cell 3 & $\mathrm{n}=3$ & $1.39 \pm 0.21$ & $<0.05$ & $<0.2$ & $<0.2$ & $7.91 \pm 0.14$ & $77.33 \pm 19.15$ & $324.33 \pm 13.86$ & $0.31 \pm 0.01$ \\
\hline Cell 4 & $\mathrm{n}=3$ & $1.57 \pm 0.27$ & $<0.05$ & $<0.2$ & $<0.2$ & $7.95 \pm 0.24$ & $73.63 \pm 11.42$ & $319.00 \pm 15.72$ & $0.31 \pm 0.02$ \\
\hline
\end{tabular}

Overall, there were no consistent trends observed when examining the concentrations of TKN, water $\mathrm{pH}, \mathrm{DO} \%$ saturation, TDS, and salinity throughout the constructed wetland cells (Figure 19). Furthermore, Kruskal Wallis Tests revealed there were no significant differences in these water chemistry values between each subsystem or the vegetated and non-vegetated subsystems of the Markham BMP:

- $\operatorname{TKN}\left(X_{0.05,5}^{2}=8.043, P=0.154\right)$

- Water $\mathrm{pH}\left(X_{0.05,5}^{2}=4.813, P=0.439\right)$

- DO \% saturation $\left(X^{2}{ }_{0.05,5}=1.982, P=0.852\right)$

- $\operatorname{TDS}\left(X^{2}{ }_{0.05,5}=3.754, P=0.585\right)$

- Salinity $\left(X_{0.05,5}^{2}=3.638, P=0.603\right)$

This suggests the wetland complex may not be functioning efficiently in terms of water quality improvements. 
(a)

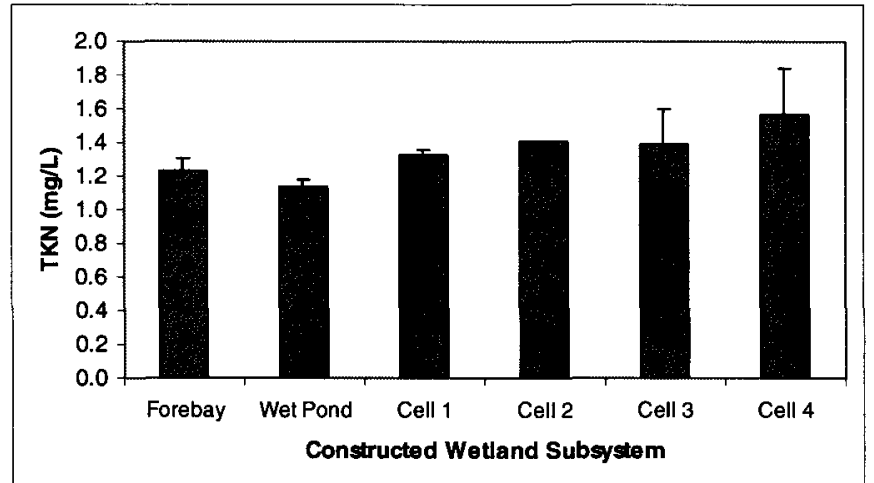

(b)
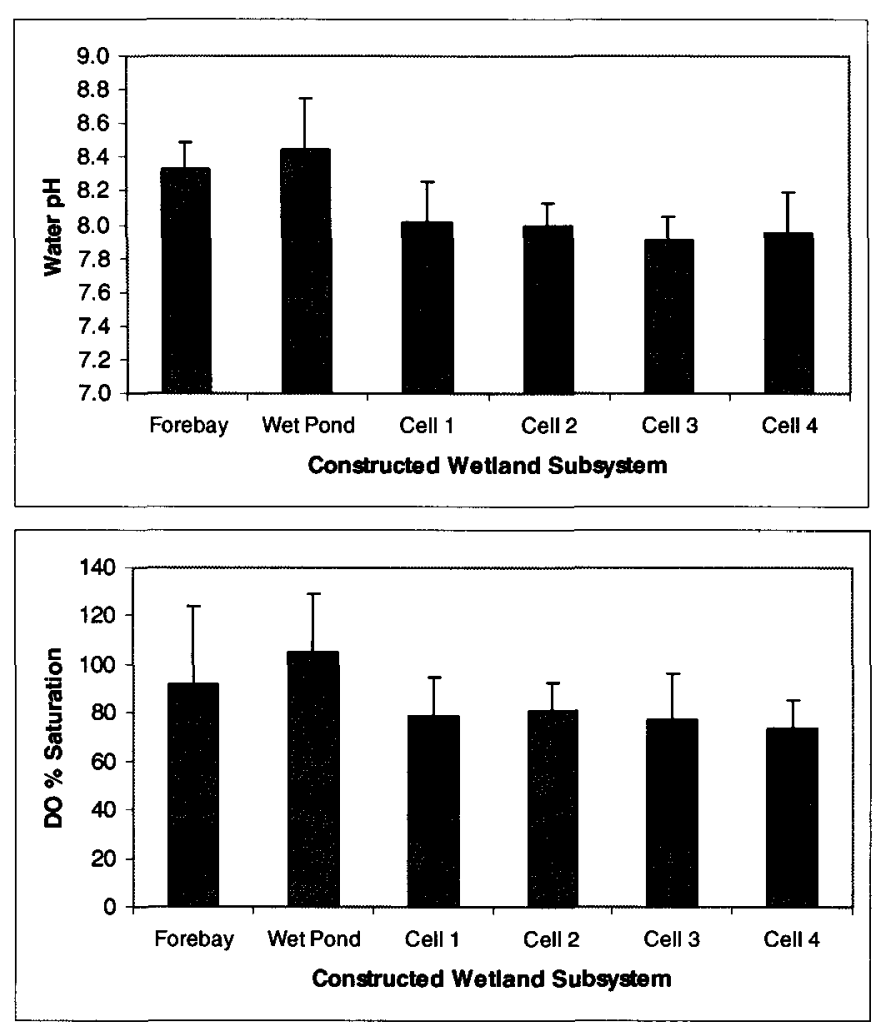

(d)

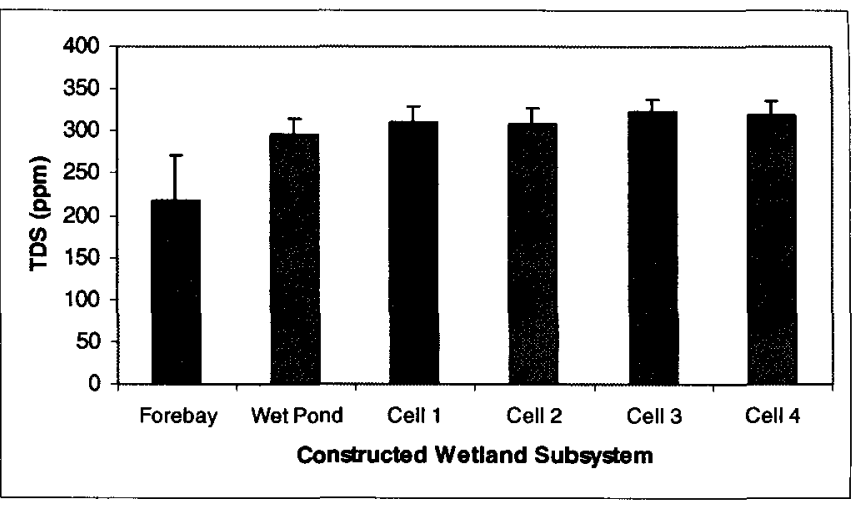

(e)

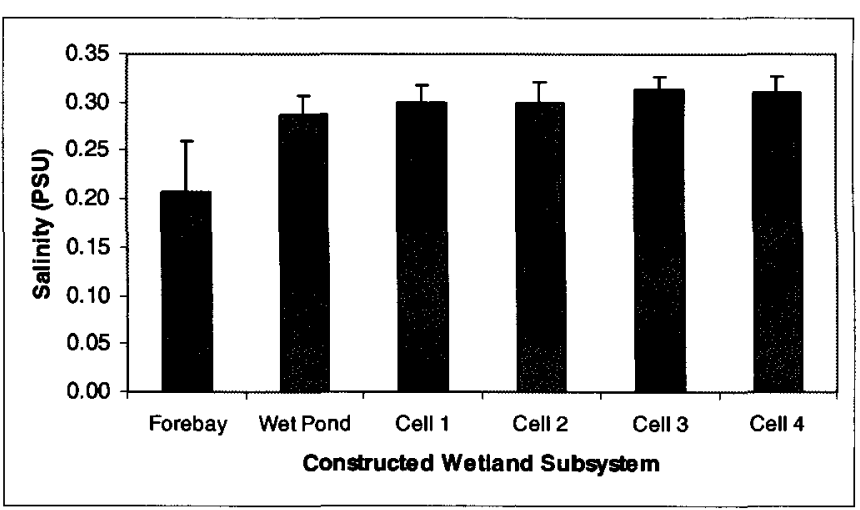

Figure 19. Mean values for (a) TKN, (b) water pH, (c) DO \% saturation, (d) TDS, and (e) salinity measurements observed in water samples collected from each subsystem of the Markham BMP site in July 2007. Error bars represent the standard error of the mean. Sample size was $\mathrm{n}=3$ for each subsystem. For all water chemistry variables measured, differences between means were not statistically significant (Kruskal Wallis Test, $P>0.05$ ). 


\subsubsection{Potential Associations between Water Chemistry Variables and Community Composition}

The assessment of water chemistry variables and their association with the presence of the wetland plant species identified during vegetation surveys involved an evaluation of the correlations between these variables and species abundance.

\subsubsection{Relationships between Water Chemistry Variables and Individual Plant Species within the Wetland Complex}

T. angustifolia, $P$. arundinacea, $S$. tabernaemontani, and $T$. latifolia were the individual plant species identified through vegetation surveys of the wetland complex. However, the sample size for correlation analysis between water chemistry and $P$. arundinacea and $S$. tabernaemontani abundance was too small for an assessment to be conducted using these species. Therefore, correlation analysis was conducted for water chemistry variables and $T$. angustifolia and T. latifolia using species abundance measures of stem density and biomass.

\section{Correlation Analysis Using Stem Density}

There were two significant relationships observed in a correlation analysis between the water chemistry measurements for TKN, pH, DO \% saturated, TDS, and salinity, and stem density measurements for T. angustifolia and T. latifolia (Table 11 and Figure 20). A statistically significant association was observed between TDS concentrations and $T$. angustifolia stem density $\left(r_{0.05,3}=0.9182, P<0.05\right)$. The direction of the correlation was positive, implying that $T$. angustifolia stem density increases with increasing TDS concentrations in the water (Figure 20d). Also, a statistically significant association was observed between the salinity of the water and $T$. angustifolia stem density $\left(r_{0.05,3}=0.8839, P<0.05\right)$. The direction of the 
(a)

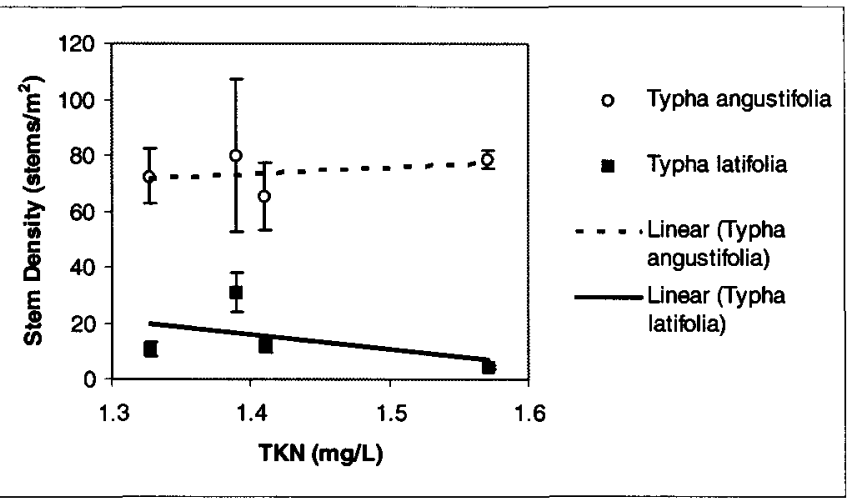

(d)

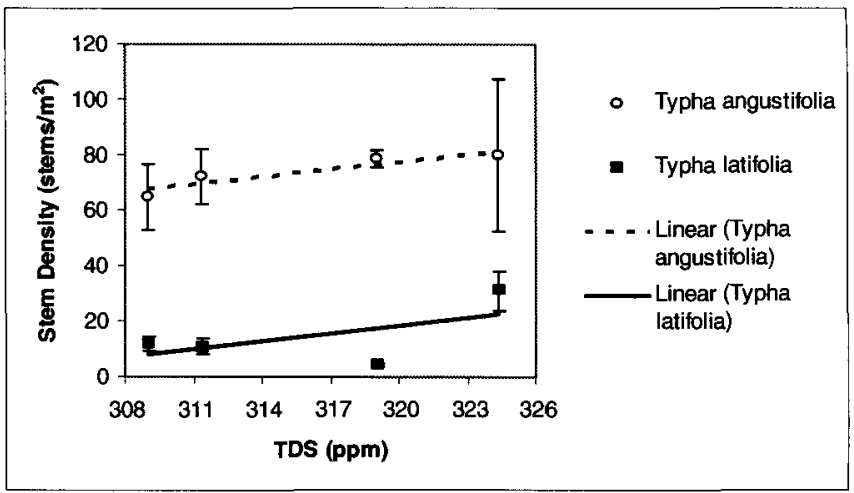

(e)

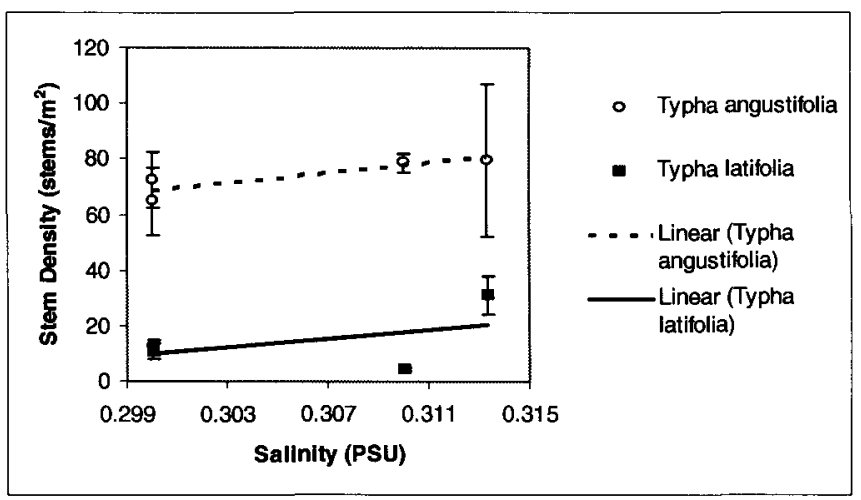

Figure 20. The relationship between Typha angustifolia and Typha latifolia stem density and water chemistry characteristics such as (a) TKN, (b) water pH, (c) DO \% saturation, (d) TDS, and (e) salinity. Open circles represent the mean stem density ( \pm 1 SE) of Typha angustifolia $(n=4)$ and filled squares represent the mean stem density $( \pm 1 \mathrm{SE})$ of Typha latifolia $(\mathrm{n}=4)$. The regression lines for Typha angustifolia and Typha latifolia are represented by a dotted line and solid line respectively. Correlation coefficients (r) for each relationship can be found in the text. Significant correlations occurred between Typha angustifolia stem density and (d) TDS $\left(r_{0.05,3}=0.9182, P<0.05\right)$, and (e) salinity $\left(r_{0.05,3}=0.8839, P<0.05\right)$. (c)

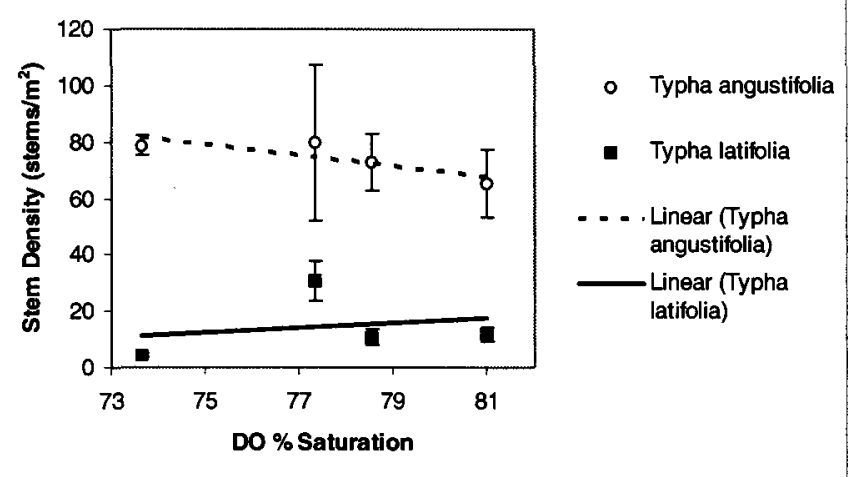


correlation was positive, implying that $T$. angustifolia stem density increases with increasing salinity in the water (Figure 20e).

Table 11: Correlation coefficient ( $\mathrm{r}$ ) values for relationships between Typha angustifolia and Typha latifolia stem density and water chemistry characteristics such as TKN, water $\mathrm{pH}$, DO \% saturated, TDS, and salinity. Significant correlations occurred between Typha angustifolia stem density and TDS $\left(r_{0.05,3}=0.9182\right.$, $P<0.05)$, and salinity $\left(r_{0.05,3}=0.8839, P<0.05\right)$. All of the other correlations were not statistically significant $(P>0.05)$ and therefore there were no systematic associations between these water chemistry characteristics and plant stem density.

\begin{tabular}{|l|l|c|c|c|c|c|}
\hline \multicolumn{2}{|c|}{ Species } & TKN & Water pH & DO \% saturated & TDS & Salinity \\
\hline Typha angustifolia & $\mathrm{n}=4$ & 0.3575 & 0.7223 & 0.8330 & $0.9182 *$ & $0.8839 *$ \\
\hline Typha latifolia & $\mathrm{n}=4$ & 0.4612 & 0.6442 & 0.2263 & 0.5843 & 0.4976 \\
\hline
\end{tabular}

\section{Correlation Analysis Using Biomass}

There were no significant relationships observed in a correlation analysis between the water chemistry measurements for TKN, $\mathrm{pH}, \mathrm{DO} \%$ saturated, TDS, and salinity, and biomass measurements for T. angustifolia and T. latifolia (Table 12 and Figure 21).

Table 12: Correlation coefficient (r) values for relationships between Typha angustifolia and Typha latifolia biomass and water chemistry characteristics such as TKN, water pH, DO \% saturated, TDS, and salinity. None of these correlations was statistically significant $(P>0.05)$ and therefore there were no systematic associations between these water chemistry characteristics and plant biomass.

\begin{tabular}{|l|l|c|c|c|c|c|}
\hline \multicolumn{2}{|c|}{ Species } & TKN & Water pH & DO \% saturated & TDS & Salinity \\
\hline Typha angustifolia & $\mathrm{n}=4$ & 0.1772 & 0.6586 & 0.4101 & 0.8427 & 0.7335 \\
\hline Typha latifolia & $\mathrm{n}=4$ & 0.2456 & 0.8067 & 0.0224 & 0.7712 & 0.7026 \\
\hline
\end{tabular}

\subsubsection{Relationships between Water Chemistry Variables and Invasive and Native Plant Species within the Wetland Complex}

Invasive species included $T$. angustifolia and $P$. arundinacea, and native species included

T. latifolia and S. tabernaemontani. Correlation analysis was conducted for water chemistry 
(a)

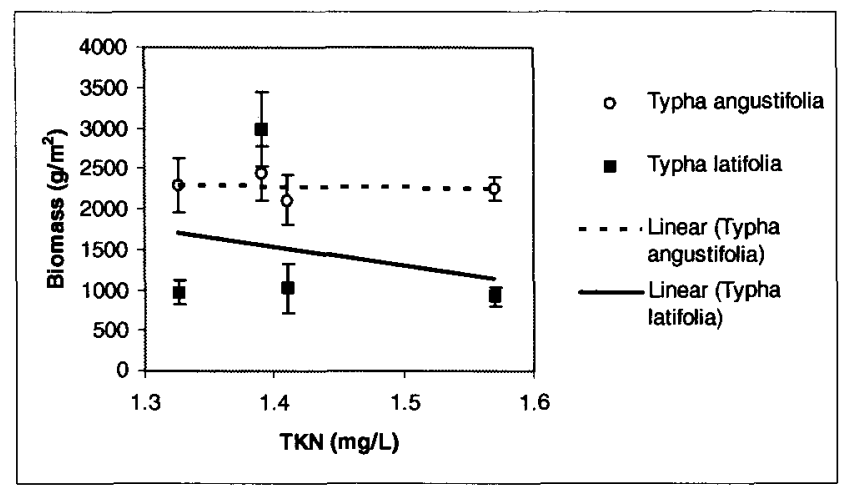

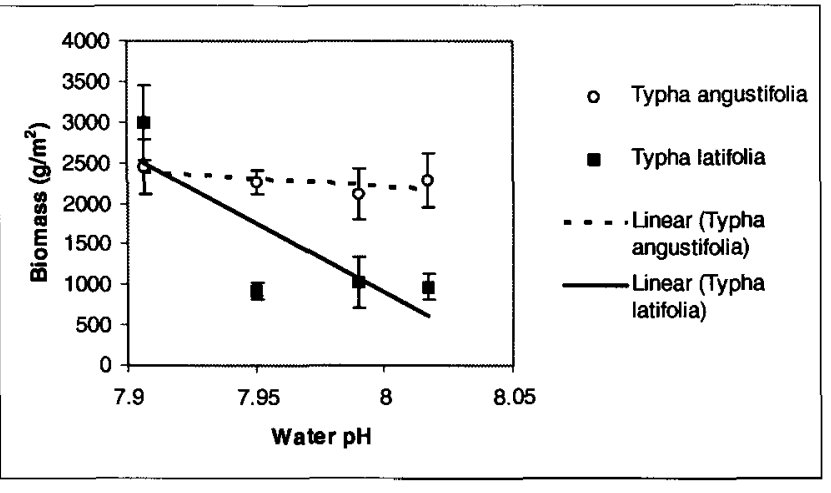

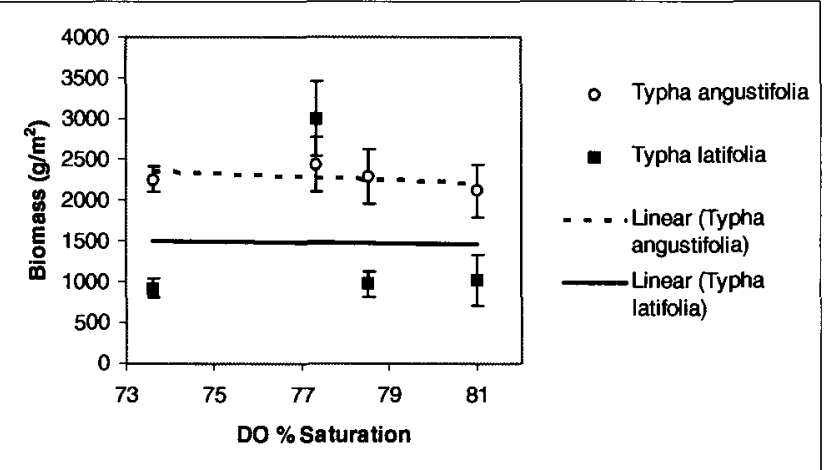

(d)

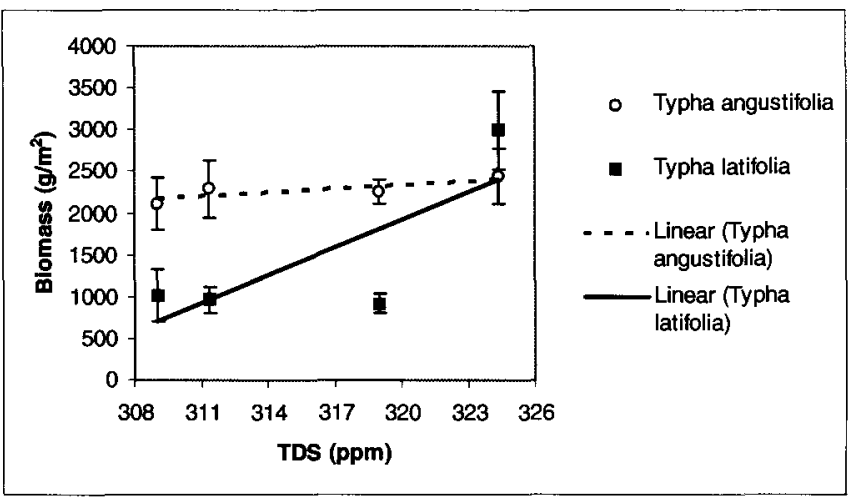

(e)

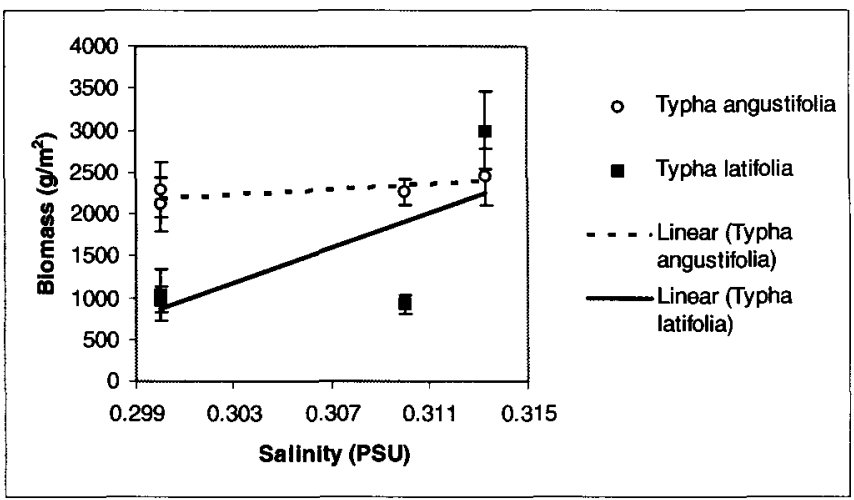

Figure 21. The relationship between Typha angustifolia and Typha latifolia biomass and water chemistry characteristics such as (a) TKN, (b) water $\mathrm{pH}$, (c) DO \% saturation, (d) TDS, and (e) salinity. Open circles represent the mean biomass $( \pm 1 \mathrm{SE})$ of Typha angustifolia $(\mathrm{n}=4)$ and filled squares represent the mean biomass ( \pm 1 SE) of Typha latifolia $(\mathrm{n}=4)$. The regression lines for Typha angustifolia and Typha latifolia are represented by a dotted line and solid line respectively. Correlation coefficients ( $r$ ) for each relationship can be found in the text. There were no significant correlations found for any of these variables and biomass.

(c) 
variables and invasive species and native species using the abundance measures of stem density and biomass.

\section{Correlation Analysis Using Stem Density}

There were no significant relationships observed in a correlation analysis between the water chemistry measurements for TKN, $\mathrm{pH}, \mathrm{DO} \%$ saturated, TDS, and salinity, and stem density measurements for invasive and native plant species (Table 13 and Figure 22).

Table 13: Correlation coefficient $(r)$ values for relationships between invasive and native species stem density and water chemistry characteristics such as TKN, water $\mathrm{pH}, \mathrm{DO} \%$ saturated, TDS, and salinity. None of these correlations was statistically significant $(P>0.05)$ and therefore there were no systematic associations between these water chemistry characteristics and plant stem density.

\begin{tabular}{|l|l|c|c|c|c|c|}
\hline \multicolumn{2}{|c|}{ Species } & TKN & Water pH & DO \% saturated & TDS & Salinity \\
\hline Invasives & $\mathrm{n}=4$ & 0.0141 & 0.5359 & 0.6500 & 0.8014 & 0.7057 \\
\hline Natives & $\mathrm{n}=4$ & 0.7192 & 0.3628 & 0.3079 & 0.4128 & 0.2717 \\
\hline
\end{tabular}

\section{Correlation Analysis Using Biomass}

There were no significant relationships observed in a correlation analysis between the water chemistry measurements for TKN, $\mathrm{pH}, \mathrm{DO} \%$ saturated, TDS, and salinity, and biomass measurements for invasive and native plant species (Table 14 and Figure 23).

Table 14: Correlation coefficient $(r)$ values for relationships between invasive and native species biomass and water chemistry characteristics such as TKN, water $\mathrm{pH}, \mathrm{DO} \%$ saturated, TDS, and salinity. None of these correlations was statistically significant $(P>0.05)$ and therefore there were no systematic associations between these water chemistry characteristics and plant biomass.

\begin{tabular}{|l|l|c|c|c|c|c|}
\hline \multicolumn{2}{|c|}{ Species } & TKN & Water pH & DO \% saturated & TDS & Salinity \\
\hline Invasives & $\mathrm{n}=4$ & 0.3274 & 0.3835 & 0.3599 & 0.6505 & 0.5101 \\
\hline Natives & $\mathrm{n}=4$ & 0.1323 & 0.8660 & 0.0520 & 0.7903 & 0.7467 \\
\hline
\end{tabular}


(a)

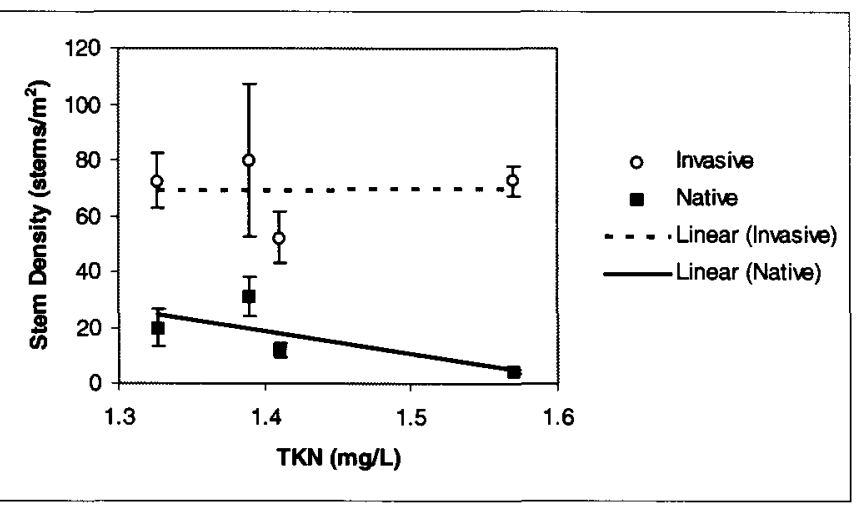

(b)

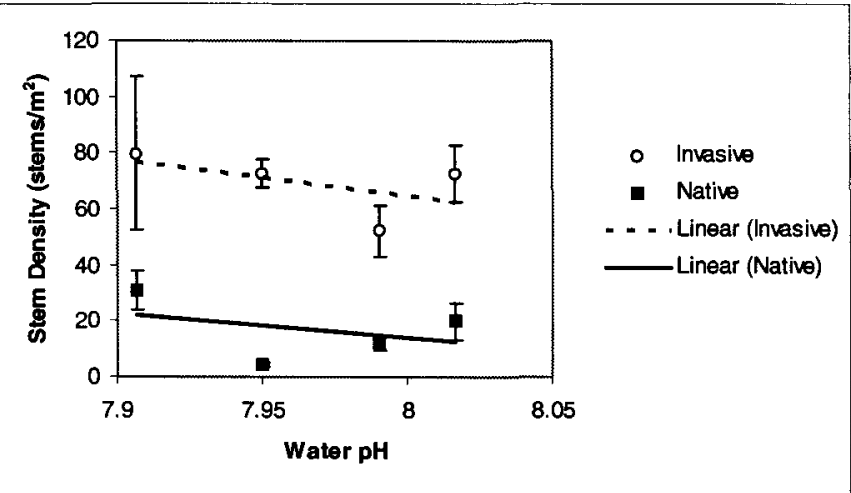

(c)

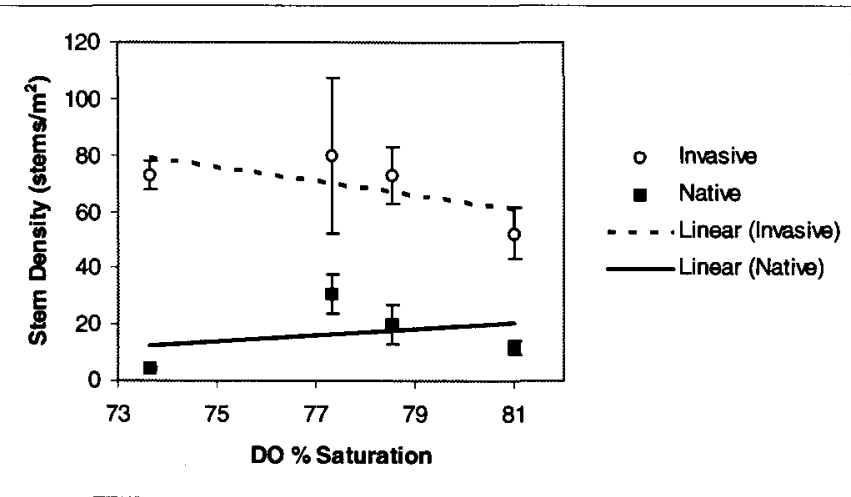

(d)

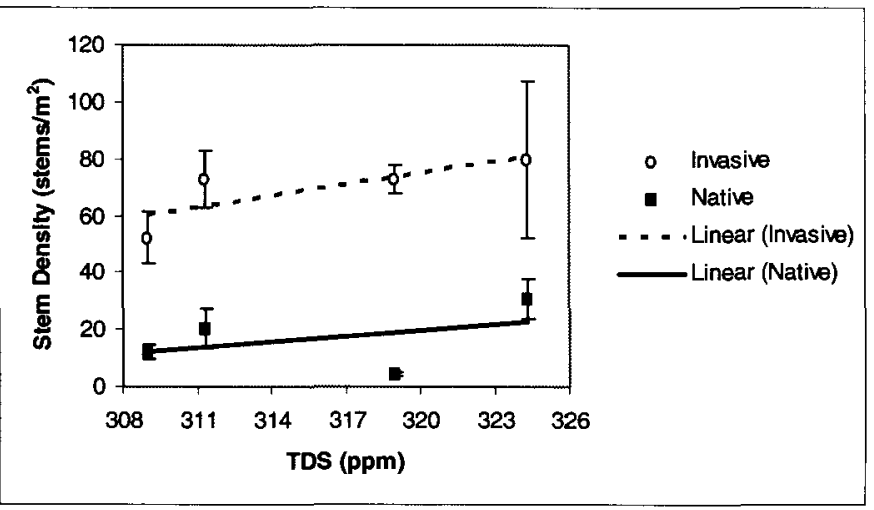

(e)

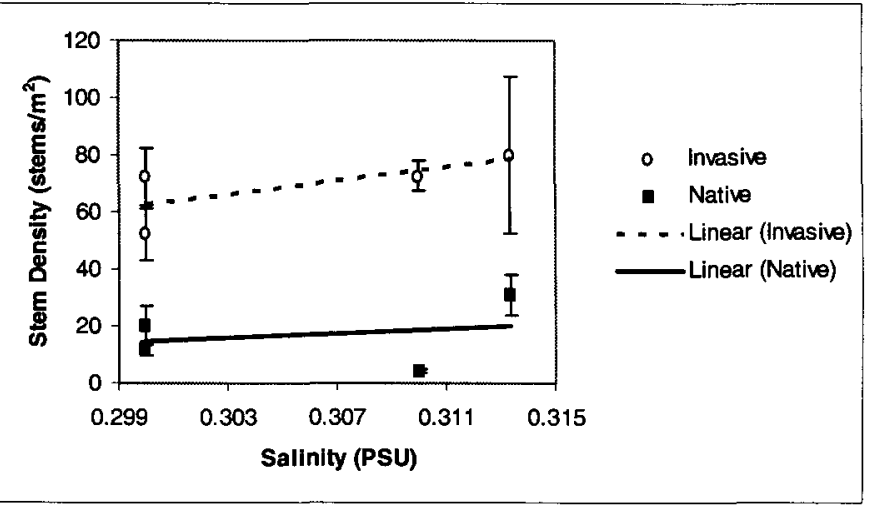

Figure 22. Relationships between mean invasive and native species stem density and water chemistry characteristics such as (a) TKN, (b) water pH, (c) DO \% saturation, (d) TDS, and (e) salinity. Open circles represent the mean stem density ( \pm 1 SE) of invasive species $(n=4)$ and filled squares represent the mean stem density ( \pm 1 SE) of native species $(n=4)$. The regression lines for invasive and native species are represented by a dotted line and solid line respectively. Correlation coefficients (r) for each relationship can be found in the text. There were no significant correlations found for any of the variables and stem density. 
(a)

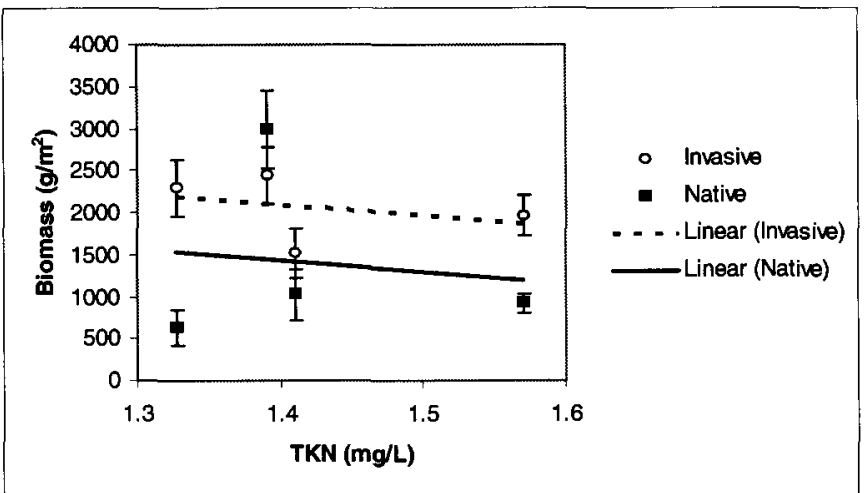

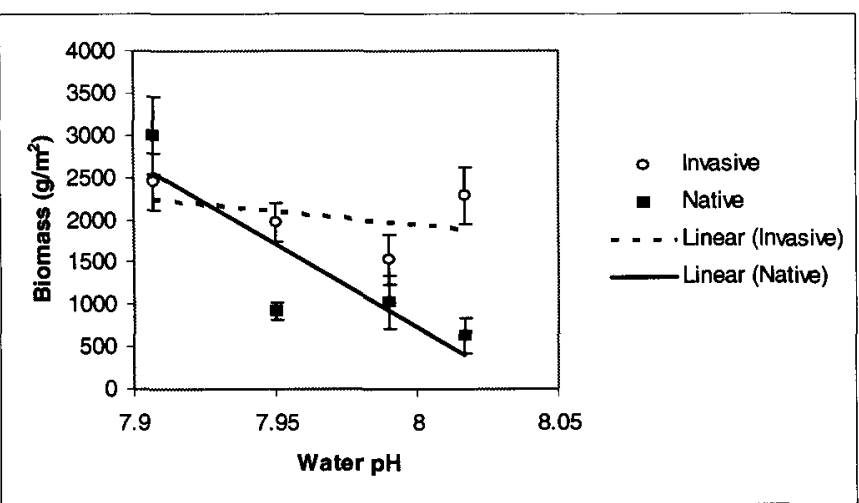

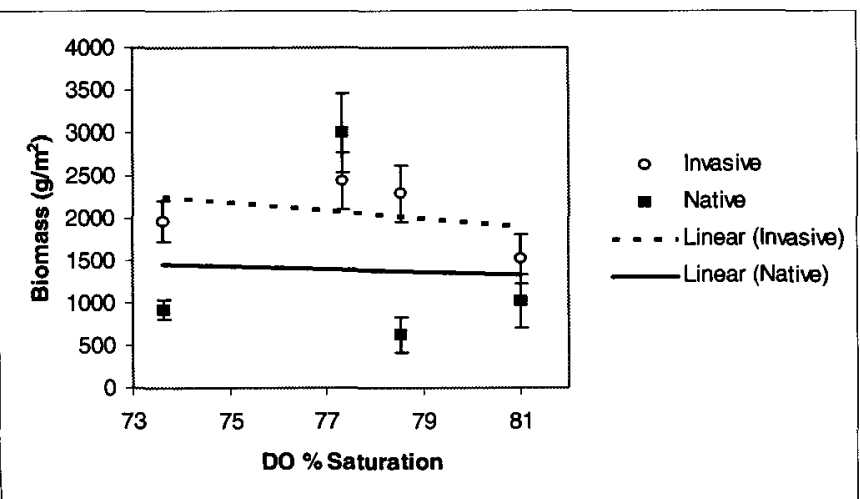

(d)

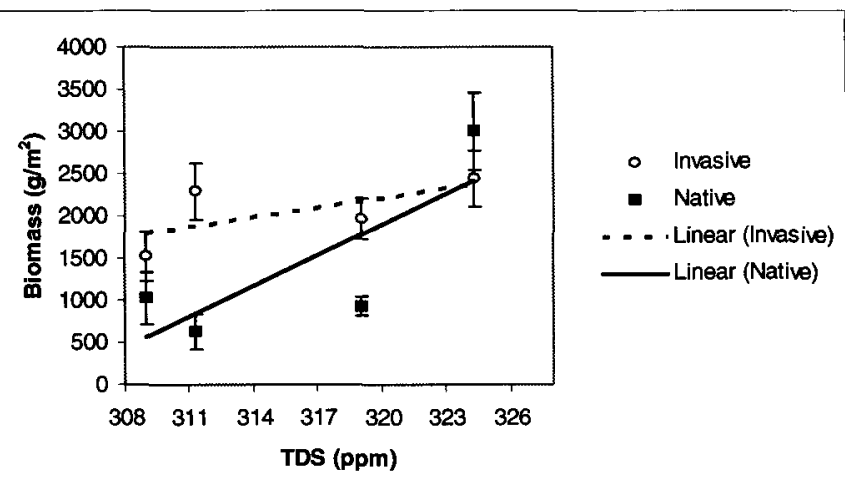

(e)

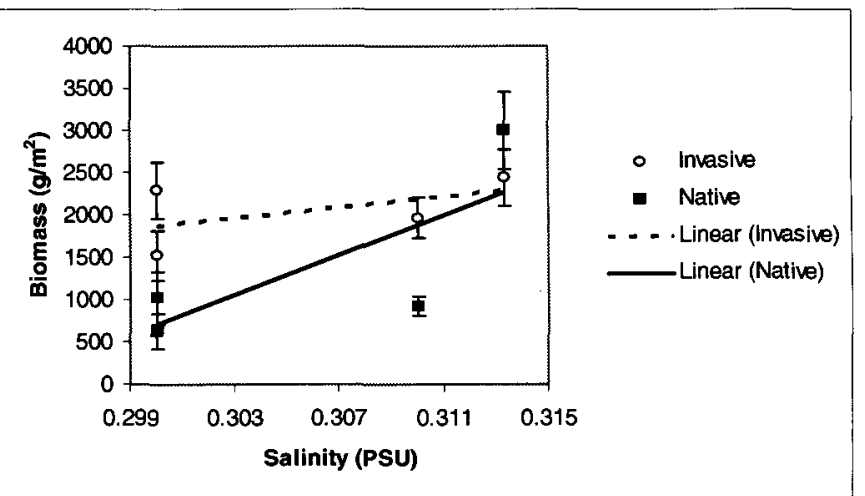

Figure 23. Relationships between mean invasive and native species biomass and water chemistry characteristics such as (a) TKN, (b)

water pH, (c) DO \% saturation, (d) TDS, and (e) salinity. Open circles represent the mean biomass $( \pm 1 \mathrm{SE})$ of invasive species $(n=4)$ and filled squares represent the mean biomass $( \pm 1 \mathrm{SE})$ of native species $(n=4)$. The regression lines for invasive and native species are represented by a dotted line and solid line respectively. Correlation coefficients (r) for each relationship can be found in the text. There were no significant correlations found for any of the variables biomass. 


\subsection{Summary of Key Results}

The vegetation community within the wetland complex of the Markham BMP was composed of four emergent plant species: T. angustifolia, T. latifolia, P. arundinacea, and $S$. tabernaemontani. Thus, there was an overall lack of biodiversity within the wetland complex. Of the species present, invasive species composition consisted of $T$. angustifolia and $P$. arundinacea, and native species composition consisted of $T$. latifolia and S. tabernaemontani. In general, all four cells in the wetland complex were dominated by invasive species, especially monocultures of T. angustifolia. Furthermore, increases in invasive species abundance were associated with a reduction in native species abundance.

Overall, there were no consistent trends observed when examining soil chemistry measurements in each cell of the constructed wetland complex. Moreover, despite the significant differences in soil chemistry variables for Cell 4 , vegetation composition and abundance were reasonably consistent in all four cells of the wetland complex. However, there were some statistically significant relationships between some soil chemistry variables and species abundance. Invasive species stem density was positively correlated with $\mathrm{NH}_{4}-\mathrm{N}$ $(P<0.05)$ and native species biomass was positively correlated with soil organic matter $(P<0.05)$. Additionally, native species biomass, in particular $T$. latifolia biomass, was positively correlated with $\mathrm{NH}_{4}-\mathrm{N}(P<0.05, P<0.01)$, plant available $\mathrm{P}(P<0.05, P<0.02)$, and plant available $\mathrm{Mg}$ $(P<0.01)$.

There were only two statistically significant relationships observed between water chemistry variables and species abundance. $T$. angustifolia stem density was positively correlated with both TDS $(P<0.05)$ and salinity $(P<0.05)$. In terms of water chemistry measurements, there also were no consistent trends observed throughout the constructed wetland 
cells. Furthermore, there seem to be no significant differences in water chemistry values between the vegetated and non-vegetated subsystems of the Markham BMP. This suggests the wetland complex may not be functioning efficiently in terms of water quality improvements. If the wetland complex is functioning efficiently as designed, then a reduction in the concentrations of variables associated with pollutants, such as TKN or salinity, should be observed as water passes through the system. 


\section{Chapter 4: Discussion and Conclusions}

\subsection{Transformation in Species Composition and Abundance from Previous Assessments of Vegetation at the Markham BMP}

According to the SWAMP (2002) study, T. latifolia (85-90\%) and P. arundinacea (8$13 \%)$ represented the overwhelming majority of the vegetation surveyed, while a small number of other species represented $<1 \%$ of species abundance. Furthermore, in 1992, a survey of the former marsh, upon which this constructed wetland is based, reported similar vegetation patterns (SWAMP, 2002).

In comparison, the wetland vegetations assessment conduced in July 2007 found the vegetation composition of the site had been transformed. Native T. latifolia was no longer the dominant species and was determined to represent only $10 \%$ of the vegetation stem density surveyed. The invasive Typha angustifolia had established at the site and become the dominant plant species with $81 \%$ of the stem density. $P$. arundinacea continued to grow in isolated patches, although it only represented $7 \%$ of the vegetation stem density surveyed.

Both the SWAMP 2002 report and this study found an overall lack of biodiversity in the wetland complex of the Markham BMP site. The only major change is that the site has now been transformed towards dominance by invasives, as T. angustifolia dominates the wetland cells.

\subsubsection{Effects of Urbanization}

Plant community changes in this wetland complex could be attributed to the influence of expanding urbanization in the area, in particular to greater water level fluctuations and contaminated stormwater runoff. Land-use adjacent the Markham BMP has intensified over the past seven years. Consequently, the area of impervious surface (i.e. rooftops, roads, sidewalks, 
parking lots) has expanded. This generally contributes to greater water level fluctuations (Mitsch and Wilson, 1996; Magee et al., 1999; Wei and Chow-Fraser, 2005). Furthermore, urbanization is associated with greater loadings of contaminants (i.e. nutrients, heavy metals, pesticides, oils, and road salts) from stormwater runoff (Wang et al., 2000; Wei and Chow-Fraser, 2005). For instance, according to SWAMP (2002), during the winter months, the Markham BMP received influent chloride concentrations above $1500 \mathrm{mg} / \mathrm{L}$. Salinity concentrations in stormwater received by this wetland complex should have continued to rise in conjunction with expanding residential and commercial development. Gradually, the majority of chloride accumulated during the winter months is flushed out of the wetland complex during the spring and summer (SWAMP, 2002). However, the influx of chloride resumes again during the winter (SWAMP, 2002). These changes in salinity could be considered a chronic stressor to this ecosystem, and could have potentially been a catalyst for shifts in species composition, dominance, richness, and community (Wetzel and Kitchens, 2007).

Furthermore, an increase in road density is strongly associated with a reduction in plant species richness (Houlahan et al., 2006). In eastern Ontario, species such as $P$. arundinacea and Typha spp. are strongly correlated with increased road density and are likely to be abundant in wetlands that are surrounded by roads (Houlahan et al., 2006). At the Markham BMP, invasive species abundance has increased and represents $88 \%$ of the vegetation stem density sampled. This site has also experienced an increase in road density since the SWAMP 2002 study due to residential and commercial development.

Generally, increased road density acts as a barrier to the dispersal of seeds by animals, alters the transport of wind-dispersed propagules, alters the hydrology, and increases sedimentation into a wetland (Houlahan et al., 2006). As a result, a diversity of plant species is 
unable to establish and proliferate in these constructed wetlands, and there is greater potential for dominance by invasive plant species (Magee et al., 1999; Owen, 1999).

In general, invasive species, such as $T$. angustifolia and $P$. arundinacea, are strong competitors (Gaudet and Keddy, 1995). In many wetlands they invade, they tend to be the dominant vegetation and can form monocultures that exclude native species and compromise native biodiversity (Magee et al., 1999). If biodiversity is lowered or unable to proliferate, the functional value of a wetland diminishes (Mitsch and Wilson, 1996; Owen, 1999). Thus, it is important to monitor any long term changes in plant community structure in order to conserve the functionality of the constructed wetland (Wetzel and Kitchens, 2007).

\subsubsection{Presence of Scirpus tabernaemontani}

One interesting development in the wetland complex of the Markham BMP is the presence of the native Scirpus tabernaemontani. This species was absent during the 2000 vegetation assessment (SWAMP, 2002). The establishment of $S$. tabernaemontani could be attributed to its tolerance to a wide range of salinity levels (Latham et al., 1991; Wetzel et al., 2004; Miklovic and Galatowitsch, 2005). According to Wetzel et al. (2004), S. tabernaemontani thrive in fresh/intermediate and intermediate salinity sites, but was not as successful in fresher environments. This species was only found in Cell 1 of the wetland complex in the Markham BMP. By design, Cell 1 is the first of the four cells to receive the influx of stormwater runoff as it travels through the system. This suggests that Cell 1 receives the most contaminated (i.e. saline) water in comparison to the other cells. However, this study found no significant differences in salinity between each of these subsystems. This may be attributed to the fact that sampling was conducted during the summer months and not during the spring when salinity concentration would be higher with melting snow. 
In general, the survival of vegetation in saline conditions depends on the level and duration of exposure (Howard and Mendelssohn, 1999). It is possible to transform the vegetation composition and plant community within a wetland in as little as 6 to 18 months but this depends on plant tolerance levels (Wetzel et al., 2004). However, where physiological tolerances overlap, competitive interactions may influence plant community structure and composition (Latham et al., 1991). Miklovic and Galatowitsch (2005) found S. tabernaemontani establishment was suppressed by the salt-tolerant $T$. angustifolia at various salinity levels. Therefore, salinity tolerance alone may not be the only explanation for the establishment of $S$. tabernaemontani at the Markham BMP.

Thus, plant species assemblages and their competitive interactions may be another variable that accounts for the presence and distribution of $S$. tabernaemontani in this wetland complex (Latham et al., 1991). During the vegetation surveys conducted in this study, $S$. tabernaemontani was found growing amongst Typha spp. It is not uncommon for this species to be found growing amongst Typha spp., especially T. latifolia (Mitsch and Gosselink, 2000; Svengsouk and Mitsch, 2001). However, characteristics such as growth rate and competitive ability are important in determining the distribution and abundance of these species. For instance, Svengsouk and Mitsch (2001) found growth rates for T. latifolia were $20 \%$ higher compared to S. tabernaemontani. Moreover, Gaudet and Keddy (1995), found the competitive ability for T. latifolia was $27 \%$ greater in comparison to S. tabernaemontani. This may account for the limited distribution of S. tabernaemontani within the wetland complex.

Moreover, growth rates and competitive ability are dependant on environmental conditions such as the availability of nutrients. According to Svengsouk and Mitsch (2001), when nutrients such as nitrogen and phosphorous are readily available, $S$. tabernaemontani 
productivity decreases as a result of competition from T. latifolia. However, if phosphorus availability is limited, $S$. tabernaemontani is able to compete much more successfully (Svengsouk and Mitsch, 2001). This can be attributed to the root morphology of $S$. tabernaemontani. This species utilizes its thick fibrous roots and vast dense network of root hairs for nutrient uptake and storage (Svengsouk and Mitsch, 2001). Nutrients are stored and conserved in order to maintain growth during nutrient poor conditions (Tanner, 1996; Svengsouk and Mitsch, 2001). In this study, there were no significant trends or differences in soil nitrogen and/or phosphorus concentrations that could account for distribution and growth of $S$. tabernaemontani solely in Cell 1.

\subsection{Interaction between Invasive and Native Plant Species at the Markham BMP}

In general, vegetation composition and abundance is a function of interspecific competition between plant species and environmental factors (Wetzel and van der Valk, 1998). The Efficient Use Hypothesis suggests that invasive species have a greater competitively ability for resources such as light and nutrients (Zedler and Kercher, 2004). This section focuses on the interspecific competition and/or relationships between plant species that may be associated with the presence and distribution of the invasive plants at the Markham BMP.

\subsubsection{Competitive Relationship between Typha angustifolia and Typha latifolia}

Over the past several years, the invasive $T$. angustifolia has become established within the wetland complex of the Markham BMP. It has displaced T. latifolia populations to become the most dominant and abundant species within the wetland, both in terms of stem density (81\%) and biomass $(70.7 \%)$. 
There have been several studies concerning the competitive interactions between $T$. angustifolia and $T$. latifolia which ultimately influence the abundance and distribution of these species (Grace and Wetzel, 1981; Weisner, 1993; Grace and Wetzel, 1998). In southern Sweden, Weisner (1993) found T. angustifolia to be competitively superior to T. latifolia when stands were fully established. T. angustifolia competitively displaced $T$. latifolia over a period of 13 years at an expansion rate of $>1 \mathrm{~m} /$ year (Weisner, 1993). Expansion by $T$. angustifolia occurred every year and was considered more or less continuous (Weisner, 1993). However, in shallower water $(<0.25 \mathrm{~m})$, this expansion rate was slower as a result of better competition from $T$. latifolia (Weisner, 1993). By contrast, in this study, cells with shallower water (Cell 2 and Cell 4) were dominated by $T$. angustifolia stem density and biomass. In fact, the only indication of better competitive ability by $T$. latifolia was in Cell 3 . Specifically, this cell was dominated by $T$. latifolia biomass (60.5\%).

Weisner (1993) attributed T. angustifolia's competitive advantage to differences in morphological characteristics between the Typha species. T. angustifolia had taller shoots and taller leaves early in the summer, enhancing their competitive ability to access light (Weisner, 1993). Furthermore, T. angustifolia's rhizomes supplied more energy to new shoots (Weisner, 1993). As a result, shoot height and standing crop increased more rapidly during the spring (Weisner, 1993). Shoot height also influences oxygen transport ability within plants, which in turn affects plant growth (Weisner, 1993). For plants growing in water, taller shoots are important for effective oxygen transport (Weisner, 1993).

Despite the findings by Weisner (1993), there are other studies with contradictory results. For instance, Grace and Wetzel (1981) found $T$. latifolia to be competitively superior to $T$. angustifolia during experimental studies conducted in Michigan, U.S.A. Moreover, Grace and 
Wetzel (1998) re-examined the same sites after 15 years and further confirmed the original findings of competitive displacement by T. latifolia. However, in order to gain further insight into the competitive interactions between $T$. latifolia and $T$. angustifolia, Grace and Wetzel (1998) also compared mixed and monoculture stands for each species. According to Grace and Wetzel (1998), the average stem density of $T$. angustifolia was $59.4 \%$ lower in mixed stands compared to monoculture stands. In contrast, the average stem density of $T$. latifolia was $32 \%$ lower in mixed stands compared to monoculture stands.

These contradictions in competitive superiority may be attributed to several factors. First, competitive ability may be influenced by the local abiotic environment, such as nutrient concentrations, latitude, and water levels (Grace and Wetzel, 1998; Tanaka et al., 2004). For instance, total phosphorous concentrations for sites investigated by Weisner (1993) were $>100$ $\mu \mathrm{g} / \mathrm{L}$, while study sites of Grace and Wetzel (1998) had total phosphorous concentrations ranging from $0.02-1 \mu \mathrm{g} / \mathrm{L}$. In general, nutrient limitations impair the competitive dominance of $T$. angustifolia (Tanaka et al., 2004). Using a parameter of nutrient availability for photosynthesis ( $\mathrm{K}_{\mathrm{NP}}$ ), Tanaka et al. (2004) established competitive interactions between $T$. latifolia and $T$. angustifolia based on nutrient limitations. $\mathrm{K}_{\mathrm{NP}}$ is a constant that increases with increasing $\mathrm{N}$ and P concentrations and indicates the availability of nutrients for growth (Tanaka et al., 2004). They found larger $\mathrm{K}_{\mathrm{NP}}$ values increased $T$. angustifolia productivity, which in turn allowed $T$. angustifolia to competitively displace $T$. latifolia. By contrast, smaller $\mathrm{K}_{\mathrm{NP}}$ values decreased $T$. angustifolia productivity, which in turn allowed $T$. latifolia to defend against $T$. angustifolia invasion (Tanaka et al., 2004). For instance, they estimated the $\mathrm{K}_{\mathrm{NP}}$ value for Weisner (1993) to be $>0.94$, which represents sufficient conditions for high productivity and competitive dominance by T. angustifolia. Furthermore, insufficient nutrients at Grace and Wetzel (1981) 
sites resulted in low productivity for $T$. angustifolia which permitted $T$. latifolia to become competitively superior (Tanaka et al., 2004).

Latitude and water levels are other factors that must be considered in conjunction with $\mathrm{K}_{\mathrm{NP}}$ values (Tanaka et al., 2004). Latitude determines how much sunlight a stand will receive which influences photosynthesis rates. Furthermore, when nutrient availability is sufficient, $T$. angustifolia productivity is higher as their taller leaves are able to photosynthesize more effectively compared to $T$. latifolia (Tanaka et al., 2004). As a result, rhizome biomass increases which influences belowground competitiveness between the Typha species (Tanaka et al., 2004). Ultimately, this will translate into enhanced aboveground competitiveness in the years to follow (Tanaka et al., 2004). Water level fluctuations are another possible influence on competitive displacement (Grace and Wetzel, 1998). T. angustifolia is the more flood tolerant species and able to endure water depths >1 m (Weisner, 1993; Mitsch and Gosselink, 2000; Tanaka et al., 2004). This can be attributed to morphological characteristics such as elongated shoots, tall narrow leaves, and larger stores of energy in rhizomes (Weisner, 1993).

\subsubsection{Potential for Typha angustifolia and Typha latifolia hybridization}

In wetlands where $T$. angustifolia and $T$. latifolia populations are sympatric, the potential for hybridization exists (Galatowitsch et al., 1999; Kuehn and White, 1999; Selbo and Snow, 2004). This is particularly true of habitats that experience altered water and soil conditions, such as constructed wetlands (Galatowitsch et al., 1999). Typha spp. are wind pollinated which also enhances the prospect of hybridization (Galatowitsch et al., 1999). Thus, the Markham BMP might be susceptible to invasion by the T. angustifolia and T. latifolia hybrid, commonly referred to as Typha $\times$ glauca. 
Typhax glauca stands are found throughout northeastern and central North America and their populations are expanding (Kuehn and White, 1999). Accurate identification of this species can be difficult, as there is considerable overlap in morphological characteristics between the hybrid and both parental species (Kuehn and White, 1999). However, generally Typha $x$ glauca has lanceolate-spatulate shaped staminate flowers and a longer spike length compared either parent (Kuehn and White, 1999).

As Typha $x$ glauca populations establish, this species can be competitively superior to both parental species and has the potential to be even more invasive (Galatowitsch et al., 1999; Kuehn and White, 1999; Selbo and Snow, 2004). Both Angeloni et al. (2006) and Boers et al. (2007) found Typha x glauca significantly decreased and suppressed plant biodiversity. This can be attributed to Typha $x$ glauca's high levels of primary productivity and ability to monopolize resources such as light, nutrients, and root space (Angeloni et al., 2006; Boers et al., 2007). Furthermore, this species has the ability to tolerate a wide range of environmental conditions, including fluctuations in water levels, eutrophication, and increased water salinity from road deicing salts (Galatowitsch et al., 1999; Kuehn and White, 1999; Boers et al., 2007).

In addition to its impacts on wetland plant biodiversity, the establishment and expansion of Typha x glauca may also hinder a wetland's ability to remove nutrients from water (Angeloni et al., 2006). Angeloni et al. (2006) found the soils of Typha $x$ glauca stands showed significant increases in soluble nutrients which may disperse into overlaying surface waters. In particular, there was 14x more ammonium, 10x more nitrate, and 10x more phosphate (Angeloni et al., 2006). Ultimately, the inability of these soils to immobilize nutrients may impede a constructed wetland's ability to remove terrestrially derived nutrients from surface water (Angeloni et al., 
2006). Moreover, elevated levels of soluble nutrients have ecological significance for downstream tributaries as there is a potential for increased eutrophication.

Despite the potential for hybridization, at the Markham BMP no Typha x glauca were identified during the July 2007 vegetation survey. There are several reasons which may explain absence of hybrids at the Markham BMP. First, the potential for hybridization depends on the amount of overlap in flowering times between T. angustifolia and T. latifolia (Selbo and Snow, 2004). For instance, Selbo and Snow (2004) found that peak flowering for T. latifolia took place 15-20 days after that of $T$. angustifolia. This suggests that there is a small proportion of female flowers that could possibly receive pollen, reducing the chances for hybridization (Selbo and Snow, 2004). Secondly, if one species of Typha dominates an area, then the proportion of the other Typha species is significantly less. This will also enhances the disparity in female flowers receptive to pollination (Selbo and Snow, 2004). Finally, maybe more time is needed for hybridization to occur and for clones with flowering shoots to be produced (Selbo and Snow, 2004). Hybrids are nearly sterile and spread by means of vegetative reproduction, forming monotypic stands (Selbo and Snow, 2004; Boers et al., 2007). This facility is just over 10 years old and perhaps ecological conditions are not yet optimal for hybrid establishment.

\subsubsection{Possible Phalaris arundinacea Suppression by Typha spp.}

Over the past several years, $P$. arundinacea abundance at the wetland complex of the Markham BMP has remained constant. This is surprising for a species that is known to be highly invasive in restored and created wetlands (Kercher et al., 2004; Adams and Galatowitsch, 2005). However, the expansion of this species in the wetland complex may have been suppressed by factors such as prolonged flooding and/or competition for light resources (Klimesova, 1994; Maurer and Zedler, 2002). For instance, Maurer and Zedler (2002) demonstrated a 73\% 
reduction in $P$. arundinacea aboveground biomass due to flooding, and a 97\% reduction in $P$. arundinacea aboveground biomass due to heavy shading.

P. arundinacea was only found in Cell 2 and Cell 4 of the Markham BMP wetland complex. These cells were fully vegetated and did not maintain a constant pool of water. Instead, these cells are subject to a wide range of water fluctuations, from high water levels as a result of stormwater runoff, to periods of drought (such were experienced during the summer of 2007). P. arundinacea prefers drier sites but is tolerant of fluctuating water levels (Owen, 1999; Maurer and Zedler, 2002; Kercher et al., 2004). This species is most often found in sites that undergo constantly changing hydrologic conditions such as Cell 2 and Cell 4 (Owen, 1999; Kercher et al., 2004). However, prolonged flooding, especially in the spring and early summer months, can effectively suppress $P$. arundinacea biomass (Klimesova, 1994). Perhaps the constant pool of water in Cell 1 and Cell 3 of the wetland complex inhibits the establishment of $P$. arundinacea in these cells.

In the two cells where $P$. arundinacea has established, Typha spp. may be out-competing this species for light resources. $P$. arundinacea is a light sensitive species and require high-light conditions (Lindig-Cisneros and Zedler, 2001). When concurrently growing vegetation in an area intercepts light, $P$. arundinacea establishment may be inhibited (Adams and Galatowitsch, 2005). Thus, existence of a dense closed canopy may be associated with the suppression of $P$. arundinacea (Morrison and Molofsky, 1998; Lindig-Cisneros and Zedler, 2002a). For instance, Perry and Galatowitsch (2003) found that a dense canopy of Echinochloa crusgalli decreased light availability for $P$. arundinacea and in turn, $P$. arundinacea biomass was reduced by more than $65 \%$. Seedlings are only able to establish when canopy gaps are present or they are created (Lindig-Cisneros and Zedler, 2002a; Lindig-Cisneros and Zedler, 2002b). Canopy gaps enhance 
the availability of light and increase light penetration which influences $P$. arundinacea germination rates (Lindig-Cisneros and Zedler, 2002a; Lindig-Cisneros and Zedler, 2002b). Typha spp. dominate the wetland complex of the Markham BMP and form a dense closed canopy. Thus, $P$. arundinacea growth may be limited solely to sections within the wetland complex characterized by a somewhat open canopy.

At the Markham BMP, $T$. latifolia biomass was greater than $P$. arundinacea in Cell 2 (23\% and 5.6\% respectively), and Cell 4 (9.1\% and $1.4 \%$ respectively) of the wetland complex. In general, $T$. latifolia does possess characteristics that allow it to compete effectively with $P$. arundinacea. These morphological characteristics include large storage rhizomes, high growth rates, and plastic leaf biomass which facilitates efficient light utilization (Wetzel and van der Valk, 1998). However, if canopy disturbances were to become more prevalent in the future, $P$. arundinacea populations could potentially spread and competitively displace native species such as T. latifolia. Wetzel and van der Valk (1998) found T. latifolia biomass was greatly reduced when grown concurrently with $P$. arundinacea and they suggest this species may be the better competitor when light and nutrient resources are not limiting (Wetzel and van der Valk, 1998). Morphological characteristics such as rapid growth rate, tall shoots with horizontally oriented leaves, and ability to spread its canopy laterally through vegetative growth facilitates $P$. arundinacea competitive abilities (Wetzel and van der Valk, 1998). It is interesting to note that T. latifolia stem density was lower than that of $P$. arundinacea in Cell $2(9 \%$ and $15 \%$ respectively), and Cell 4 (4\% and 7\% respectively) in the wetland complex of the Markham BMP. This suggests that $P$. arundinacea does have the potential to displace $T$. latifolia; however, deficiencies in resources may be preventing $P$. arundinacea from reaching its full capacity. 


\subsection{Relationship between Plant Species and Environmental Conditions at the Markham BMP}

Vegetation composition and abundance is a function of both interspecific competition between plant species and environmental factors (Wetzel and van der Valk, 1998). The Broader

Tolerance Hypothesis suggests that invasive species are able to tolerate a wider range of environmental conditions compared to other species (Zedler and Kercher, 2004). This section focuses on the environmental factors that may be associated with the presence and distribution of the invasive plants at the Markham BMP.

\subsubsection{Association between Plant Species and Soil Chemistry Variables}

In addition to interspecific competition, native and invasive plant species composition and abundance may also be influenced by environmental factors, such as soil chemistry (Templer et al., 1998; Wetzel and van der Valk, 1998). For instance, the availability of soil nutrients influences soil fertility which in turn influences vegetation composition and abundance (Schooler et al., 2006). Plant species place differential demands on nutrient resources, resulting in variations in peak biomass and nutrient availability for concurrently growing vegetation (Templer et al., 1998). In general, areas with high fertility are associated with fewer species and dominant species of greater biomass (Schooler et al., 2006). In particular, Typha spp. thrive in these conditions and form monotypic stands (Svengsouk and Mitsch, 2001).

In wetland environments, the primary limiting nutrient for plant growth is commonly considered to be nitrogen, followed by phosphorus (Schooler et al., 2006). However, in urban wetlands, phosphorus has been found to be the primary limiting nutrient for plant growth (Woo and Zedler, 2002). Other nutrients, such as potassium and magnesium, also have the potential to be limiting nutrients in wetland ecosystems (Schooler et al., 2006). This study attempted to 
identify any associations between soil characteristics, such as nutrients, and the presence and/or abundance of emergent plant species identified at the Markham BMP site. A simple univariate analysis was used in order to identify any general relationships that may exist. It is important to note that stem density and aboveground biomass were measured for each species; however, belowground biomass was not. Therefore, any failure to observe significant correlations between invasive and native plant species and various soil characteristics may be attributed to undetected belowground responses to soil variables (Mahaney et al., 2004).

For this study, ammonium $\left(\mathrm{NH}_{4}-\mathrm{N}\right)$ and nitrate $\left(\mathrm{NO}_{3}-\mathrm{N}\right)$ were the forms of nitrogen measured and utilized in correlation analysis. There were no significant correlations between any of the invasive and native plant species identified at the Markham BMP wetland complex and $\mathrm{NO}_{3}-\mathrm{N}$ concentrations in the soil. Both Templer et al. (1998) and Schooler et al. (2006) also found no significant associations between species such as $T$. angustifolia and $P$. arundinacea and $\mathrm{NO}_{3}-\mathrm{N}$ concentrations. However, there are studies which demonstrate significant correlations between $\mathrm{NO}_{3}-\mathrm{N}$ concentrations and plant biomass for the species found at the Markham BMP wetland complex. For instance, Green and Galatowitsch (2002) demonstrated that the competitive ability and dominance of $P$. arundinacea over native species populations was enhanced with increasing $\mathrm{NO}_{3}-\mathrm{N}$ concentrations. In fact, $P$. arundinacea shoot biomass doubled in response to high $\mathrm{NO}_{3}-\mathrm{N}$ concentrations (Green and Galatowitsch, 2002). Furthermore, Zhu and Sikora (1995) found $P$. arundinacea has a greater $\mathrm{NO}_{3}-\mathrm{N}$ removal capacity compared to species such as T. latifolia and Scirpus spp.

In contrast, there were significant correlations between the invasive and native plant species identified at the Markham BMP wetland complex and $\mathrm{NH}_{4}-\mathrm{N}$ concentrations in the soil. Native species biomass ( $T$. latifolia and S. tabernaemontani) $(P<0.01)$ and invasive species stem 
density $(T$. angustifolia and Phalaris arundinacea) $(P<0.05)$ were correlated positively with $\mathrm{NH}_{4}-\mathrm{N}$ concentration. Furthermore, $T$. latifolia biomass alone was correlated positively with ammonium $\left(\mathrm{NH}_{4}-\mathrm{N}\right)$ concentration $(P<0.02)$. Both Dyhr-Jensen and Brix (1996) and Brix et al. (2002) also observed significant associations between species such as T. latifolia and $\mathrm{NH}_{4}-\mathrm{N}$ concentrations. What is more Zhu and Sikora (1995) observed $P$. arundinacea had a greater $\mathrm{NH}_{4}-\mathrm{N}$ removal capacity compared to species such as T. latifolia and Scirpus spp. T. latifolia maintains higher relative growth rates in soils where $\mathrm{NH}_{4}-\mathrm{N}$ was the primary nitrogen source and pH levels vary from near neutral to as low as 4 (Dyhr-Jensen and Brix, 1996; Brix et al., 2002). Relationships between plant species and soil $\mathrm{pH}$ were also examined in this study. Similar to Schooler et al. (2006), there were no significant correlations detected. In general, constructed wetlands retain neutral $\mathrm{pH}$ levels ranging from 6.7 to 7.2 (Mitsch and Gosselink, 2000). The $\mathrm{pH}$ levels of soils in the wetland complex of the Markham BMP were slightly more alkaline averaging 7.77 with low variances among the measurements obtained.

There are studies which demonstrate no significant correlations between $\mathrm{NH}_{4}-\mathrm{N}$ concentrations and plant productivity for the species found at the Markham BMP wetland complex. For instance, Templer et al. (1998) observed no significant differences in $\mathrm{NH}_{4}-\mathrm{N}$ concentrations between $T$. angustifolia and other invasive plant species. Moreover, Schooler $e t$ al. (2006) found no significant associations between $P$. arundinacea and $\mathrm{NH}_{4}-\mathrm{N}$ concentrations.

The results of the nitrogen associations in this study may be attributed to the waterlogged or flooded soil conditions of wetlands (Mitsch and Gosselink, 2000; Scholz, 2006). Diffusion rates of oxygen into water and sediment are sluggish in these environments, which leads to the near ananoxic conditions in wetland soils (Matsui and Tsuchiya, 2006; Scholz, 2006). Any change in redox potential greatly influences the availability of nutrients and plant growth 
(Templer et al., 1998). For instance, nitrification of $\mathrm{NH}_{4}$ (a process which produces $\mathrm{NO}_{3}$ ) is depressed in waterlogged and reduced soils (Dyhr-Jensen and Brix, 1996; Templer et al., 1998; Brix et al., 2002). Thus, even though the majority of plants preferentially absorb $\mathrm{NO}_{3}-\mathrm{N}, \mathrm{NH}_{4}-\mathrm{N}$ becomes the primary nitrogen source for plants (Dyhr-Jensen and Brix, 1996; Mitsch and Gosselink, 2000; Brix et al., 2002; Scholz, 2006). Some plants are able to absorb $\mathrm{NH}_{4}-\mathrm{N}$ directly, while others have adaptations which facilitate $\mathrm{NH}_{4}-\mathrm{N}$ oxidization to $\mathrm{NO}_{3}-\mathrm{N}$ in the rhizophere layer (Mitsch and Gosselink, 2000; Scholz, 2006).

Aeration of this thin soil layer occurs when oxygen is transported from plant shoots to their roots through specialized structures called aerenchyma (Mitsch and Gosselink, 2000; Kennedy and Mayer, 2002; Matsui and Tsuchiya, 2006; Scholz, 2006). Oxygen is then released into the surrounding sediment; however, deeper soil layers generally remain anoxic (Mitsch and Gosselink, 2000; Kennedy and Mayer, 2002; Matsui and Tsuchiya, 2006; Scholz, 2006). Thus, the existence of oxidized microsites promotes anoxic activity in an otherwise ananoxic environment (Kennedy and Mayer, 2002). Matsui and Tsuchiya (2006) found Typha spp. growth occurs efficiently in ananoxic environments. When grown in these conditions, $T$. angustifolia root porosity and root mass ratio increases, and T. latifolia root diameter increases. As a result, root anoxic respiration rates are enhanced, which improves nutrient uptake and growth rates (Matsui and Tsuchiya, 2006).

Changes in redox potential of wetland soils can also alter the availability of other important nutrients for plant growth (Mitsch and Gosselink, 2000; Scholz, 2006). For instance, phosphorus availability generally increases in waterlogged and/or flooded soils (Mitsch and Gosselink, 2000). In reduced conditions, phosphorus is no longer adsorbed to particles (i.e. ferric and aluminium oxides) and can be released into the environment (Scholz, 2006). Plant 
available phosphorus, potassium, and magnesium were also measured and utilized in a correlation analysis. At the Markham BMP wetland complex, native species biomass, ( $T$. latifolia and S. tabernaemontani) was correlated positively with plant available phosphorus $(P<0.05)$ and plant available magnesium $(P<0.01)$. Furthermore, $T$. latifolia biomass alone was correlated positively with plant available phosphorus $(P<0.01)$, and plant available magnesium $(P<0.01)$.

In terms of Typha spp., Grace (1988) also demonstrated a relationship between nutrients and T. latifolia biomass. The addition of nutrients, such as nitrogen, phosphorous, and potassium, was found to enhance T. latifolia shoot density and biomass (Grace, 1988). However, in contrast to this study, Templer et al. (1998) found higher phosphorous concentrations were significantly associated with $T$. angustifolia stands. Moreover, Ulrich and Burton (1998) found nitrogen and phosphorous, not potassium, to be effective in the growth of both $T$. latifolia and $T$. angustifolia. There were no significant associations observed between potassium concentrations and plant species in this study. Furthermore, Schooler et al. (2006) and Houlahan et al. (2006) observed no relationship between magnesium concentrations and both invasive species (i.e. Phalaris arundinacea) and native species respectively. Lastly, in terms of Phalaris arundinacea, other studies also have not detected a relationship between the addition of nutrients (i.e. nitrogen, phosphorous, and potassium) and shoot density and/or biomass (Maurer and Zedler, 2002; Kercher and Zedler, 2004b; Schooler et al., 2006).

To further supplement the relationship analysis of nutrients, associations between plant species and soil organic matter were also examined in this study. Results indicate that native species biomass (T. latifolia and S. tabernaemontani) was correlated positively with percent soil organic matter $(P<0.05)$. However, this relationship lacks coincidence with the literature that 
suggests that soil organic matter can tie up nutrients rendering them unavailable for plant growth (Mitsch and Gosselink, 2000).

Typha dominated wetlands tend to produce a large amount of litter, which forms thick layers that decompose very slowly (Findlay et al., 1990; Fickbohm and Zhu, 2006). Typha stems actually spend an extended period of time in a dead standing position and do not immediately fall to the ground (Fickbohm and Zhu, 2006). It has even been suggested that the accumulation of Typha litter actually decreases the quantity of soil organic matter (Fickbohm and Zhu, 2006). In general, created wetlands tend to have low levels of soil organic matter due to the slow decomposition rates in the ananoxic conditions (Cole et al., 2001; Scholz, 2006).

\subsubsection{Association between Plant Species and Water Chemistry Variables}

Another environmental factor that may influence native and invasive plant species composition and abundance is water chemistry (Ehrefeld and Schneider, 1991; Goslee et al., 1997). This is of particular importance for wetlands receiving inputs of stormwater runoff which is known to contain higher sodium, heavy metals, and nutrients levels (Owen, 1999). For instance, Ehrefeld and Schneider (1991) found surface water chemistry associated with stormwater runoff was linked to a reduction in native species and an increase in invasive species. Due to this relationship between water chemistry and wetland plants, ecologists have attempted to use plants as indicators of local water quality conditions (Goslee et al., 1997).

This study attempted to investigate any associations between water chemistry characteristics and the presence and/or abundance of emergent plant species identified at the Markham BMP site. A simple univariate analysis was used in order to identify any general relationships that may exist. Water chemistry variables included total Kjeldahl nitrogen (TKN), water $\mathrm{pH}$, dissolved oxygen, total dissolved solids (TDS) and salinity. 
In terms of nutrients (i.e. nitrogen and phosphorus), development such as that occurring in the area surrounding the Markham BMP site, is usually associated with wetland eutrophication (Ehrefeld and Schneider, 1991). However, at the Markham BMP wetland complex, there were no significant correlations between any of the invasive and native plant species and TKN. Contrary to the findings of this study, Hench et al. (2003) found wetland plants, such as Typha, Scirpus, and Juncus spp., to have a statistically significant relationship with the removal of TKN. Houlahan et al. (2006) also observed a significant relationship between nitrogen and phosphorous in water samples and species richness, suggesting that eutrophication causes a wetland to be dominated by a small number of species such as Typha spp. In contrast, Nicholson (1995) observed surface water nitrate levels were not significantly correlated with wetland vegetation. Moreover, phosphorus levels were also not as significantly correlated with wetland vegetation (Nicholson, 1995). Plant uptake is considered an important mechanism for the removal of phosphorous in wetland surface water (Kennedy and Mayer, 2002). However, as discussed in section 3.3, trends and correlations for dissolved P measurements could not be assessed in this study.

In terms of water $\mathrm{pH}$ and dissolved oxygen, there also were no significant correlations observed for any of the invasive and native plant species identified at the Markham BMP wetland complex. However, there have been studies which demonstrate a relationship between variables such as $\mathrm{pH}$, and plant community composition and distribution (Nicholson, 1995; Goslee et al., 1997). Furthermore, dissolved oxygen was also found to be associated with wetland vegetation (Kennedy and Mayer, 2002; Hench et al., 2003; Thullen et al., 2005). This can be attributed to plant adaptations that allow them to release oxygen into the rhizosphere layer, which in turn provides additional dissolved oxygen for surface waters (Kennedy and 
Mayer, 2002; Hench et al., 2003). In contrast, reduced dissolved oxygen concentrations have also been observed within dense vegetation stands, which impedes nitrification and the decomposition of organic matter (Thullen et al., 2005).

Of all the water chemistry relationships analyzed, significant associations were only observed for TDS and salinity. In general, stormwater runoff contains high concentrations of trace elements and sodium (Owen, 1999). In this study, T. angustifolia stem density was correlated positively with both TDS and salinity $(P<0.05)$. In terms of TDS, Borin et al. (2001) also observed a significant positive relationship between wetland plants (i.e. Phragmites australis, T. latifolia, and Carex elata) and this water chemistry feature. Compared to the treatments, these wetland plants reduced TDS loss by $78 \mathrm{~g} / \mathrm{m}^{2}$ (Borin et al., 2001).

In terms of salinity, other studies have also observed a significant relationship between $T$. angustifolia and salinity (Panno et al., 1999; Miklovic and Galatowitsch, 2005). Panno et al. (1999) observed T. angustifolia dominance and diminished species diversity at a site with high $\mathrm{NaCl}$ concentrations associated with road salt runoff. Moreover, they suggest that $T$. angustifolia is better adapted for establishment and growth in these saline conditions (Panno et al., 1999). Similarly, Miklovic and Galatowitsch (2005) found T. angustifolia dominance increased with increasing salinity, and that at higher salinity levels, there was a reduction in native species diversity and species richness. Salinity impacts can be direct (i.e. seedling development, toxicity or osmotic effects) or indirect (i.e. interspecific competition from salt-tolerant plant species). Thus, $T$. angustifolia seems to be competitively superior to native species in saline environments (Miklovic and Galatowitsch, 2005). 


\subsubsection{Unexpected Observations between Environmental Variables and Plant Species Abundance within the Wetland Complex}

Among the soil chemistry and water chemistry relationships that were not statistically significant, some interesting associations were observed. In general, these associations lacked coincidence with the literature.

In terms of the soil chemistry variables, several unexpected results were observed.

Literature suggests that areas with high fertility are associated with dominant species of greater biomass and that the addition of nutrients (i.e. $\mathrm{NH}_{4}-\mathrm{N}, \mathrm{NO}_{3}-\mathrm{N}$, phosphorous, potassium) enhances species stem density and biomass (Grace, 1988; Svengsouk and Mitsch, 2001; Green and Galatowitsch, 2002; Schooler et al., 2006). However, contradictory indications were observed in this study. For instance, $P$. arundinacea stem density was negatively correlated with $\mathrm{NH}_{4}-\mathrm{N}$ and plant available $\mathrm{P}$ (Figure 11a and 12a). Also, invasive species stem density and biomass was negatively correlated with $\mathrm{NO}_{3}-\mathrm{N}$, plant available potassium, and plant available magnesium (Figure 15b, 16b and c, 17b, 18b and c).

In terms of the water chemistry variables, there were more unexpected results observed. For instance, literature suggests eutrophication causes wetlands to be dominated by a small number of species such as Typha spp. (Houlahan et al., 2006). However, T. latifolia stem density and biomass was negatively correlated with TKN in this study (Figure 20a and 21a). This may be attributed to the complexity of plant competition. One or more species may respond better to higher nutrients which results in an apparently negative relationship for another species.

\subsubsection{Comparison of Water Chemistry Measurements with Previous Assessments of Water Quality at the Markham BMP}

As discussed in section 3.3.3, there were no consistent trends or significant differences in water chemistry values between each wetland cell of the Markham BMP. This suggests the 
wetland complex may not be functioning efficiently in terms of water quality improvements. Another approach to assessing the functionality of the Markham BMP facility is to evaluate current measurements against those from previous assessments of water quality and to compare past and present measurements to regulatory limits and guidelines. However, it is important to note that the previous assessments of water quality were conducted at different times of the year, throughout all four seasons. The SWAMP (2002) survey was conducted in 1998/1999 and the baseline survey was conducted in 1992/1993. Thus, these assessments are an honest representation of conditions at the site. On the other hand, the survey for the current study was conducted in July 2007 and provides a limited snapshot of the conditions at the Markham BMP. Moreover, this was a particularly dry month which may bias the measurements observed. Therefore, any direct comparisons between surveys are made with caution.

A comparison of effluent water chemistry measurements and regulatory criteria for water quality can be found in Table 15. According to the guidelines in Table 15, concentrations observed at the Markham BMP and former North Pond are within regulatory limits except for $\mathrm{Cu}$ and $\mathrm{Zn}$. Concentrations of $\mathrm{Zn}$ were only acceptable during the 1998/1999 survey. These metals represent common contaminants found in urban stormwater runoff (SWAMP, 2002).

The 1998/1999 and 1992/1993 surveys both reported reductions in phosphate, $\mathrm{Cu}$, and $\mathrm{Zn}$ concentrations in effluent water. According to the SWAMP (2002) study, the removal efficiencies for phosphate, $\mathrm{Cu}$, and $\mathrm{Zn}$, during summer/fall surveys were $89 \%, 65 \%$, and $65 \%$ respectively. The 1992/1993 baseline survey also demonstrated phosphate, $\mathrm{Cu}$, and $\mathrm{Zn}$ reductions in effluent waters; however, they were not as efficient as those reported in the 1998/1999 surveys (SWAMP, 2002). Unfortunately, current dissolved $\mathrm{P}, \mathrm{Cu}$, and $\mathrm{Zn}$ 
Table 15: A comparison between water chemistry measurements observed during various assessments of the Markham BMP site and regulatory limits and guidelines. Threshold concentrations were derived from literature, the Stormwater Assessment Monitoring and Performance Program, the Ontario Provincial Water Quality Objectives, and the US Environmental Protection Agency. The remaining concentrations represent measurements observed in water samples collected from the outlet of the former North Pond (1992/1993) and Markham BMP (1998/1999; July 2007).

\begin{tabular}{|c|c|c|c|c|c|}
\hline & $\begin{array}{c}\text { TKN } \\
(\mathbf{m g} / \mathbf{L})\end{array}$ & $\begin{array}{c}\text { Phosphate } \\
(\mathbf{m g} / \mathbf{L})\end{array}$ & $\begin{array}{c}\mathbf{C u} \\
(\mathbf{m g} / \mathbf{L})\end{array}$ & $\begin{array}{c}\mathbf{Z n} \\
(\mathbf{m g} / \mathbf{L})\end{array}$ & $\begin{array}{c}\text { Chloride } \\
(\mathbf{m g} / \mathbf{L})\end{array}$ \\
\hline Threshold Values & $2.0^{4}$ & $0.1^{3}$ & $0.005^{1,2}$ & $0.02^{1,2}$ & $250^{1}$ \\
\hline $\begin{array}{c}\text { Baseline Survey } \\
(1992 / 1993)\end{array}$ & 1.66 & 0.02 & 0.010 & 0.036 & 96.4 \\
\hline $\begin{array}{c}\text { SWAMP Survey } \\
(1998 / 1999)\end{array}$ & 0.76 & 0.01 & 0.008 & 0.011 & 114.7 \\
\hline $\begin{array}{c}\text { Current Survey } \\
(J u l y ~ 2007)\end{array}$ & 1.57 & N/A & $<0.2$ & $<0.2$ & N/A \\
\hline
\end{tabular}

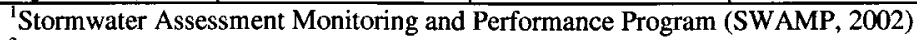

${ }^{2}$ Ontario Provincial Water Quality Objectives (MOEE, 1994)

${ }^{3}$ US Environmental Protection Agency (EPA, 1986)

${ }^{4}$ Ribaudo, 1989

concentrations and trends could not be assessed and compared in this study. Measurements for these variables were below detectable limits and therefore no trends or correlations could be determined.

A summary of similar influent and effluent water chemistry values over a period of fifteen years can be found in Tables 16, 17 and 18. Values for the July 2007 are found in Table 16. Values for the $1998 / 1999$ and $1992 / 1993$ survey are found in Tables 17 and 18 respectively. In terms of TKN concentrations, during collective wet and dry weather events, the present study demonstrated an increase in TKN levels by the time water reached Cell 4 of the wetland complex (Table 16). In fact, the present TKN concentrations in effluent water of the Markham BMP are similar to those in 1992/1993 survey (Table 16 and 18). However, the 1992/1993 survey demonstrated an overall reduction in TKN concentrations in effluent water during collective wet and dry weather events (Table 18). Moreover, a similar outcome was evident in the 1998/1999 survey (Table 17). According to the SWAMP (2002) study, the removal efficiency for ammonia (a constituent of TKN) during wet weather events was $22 \%$ in 
Table 16: July 2007 water chemistry measurements observed in water samples collected in the Markham BMP during wet weather and dry weather events. The forebay values characterize inlet estimates and Cell 4 values characterize outlet estimates.

\begin{tabular}{|c|c|c|c|c|c|c|}
\hline & Subsystem & $\begin{array}{c}\mathrm{TKN} \\
(\mathbf{m g} / \mathbf{L})\end{array}$ & $\begin{array}{c}\text { Dissolved P } \\
(\mathrm{mg} / \mathrm{L})\end{array}$ & $\underset{(\mathrm{mg} / \mathrm{L})}{\mathrm{Cu}}$ & $\underset{(\mathbf{m g} / \mathbf{L})}{\mathrm{Zn}}$ & $\begin{array}{c}\text { Salinity } \\
\text { (PSU) }\end{array}$ \\
\hline $\begin{array}{l}\text { Wet } \\
\text { Weather }\end{array}$ & Forebay & 1.26 & $<0.05$ & $<0.2$ & $<0.2$ & 0.14 \\
\hline Sample & Cell 4 & 1.46 & $<0.05$ & $<0.2$ & $<0.2$ & 0.34 \\
\hline $\begin{array}{l}\text { Dry } \\
\text { Weather }\end{array}$ & Forebay & 1.21 & $<0.05$ & $<0.2$ & $<0.2$ & 0.24 \\
\hline Sample & Cell 4 & 1.63 & $<0.05$ & $<0.2$ & $<0.2$ & 0.30 \\
\hline $\begin{array}{l}\text { Wet \& Dry } \\
\text { Weather }\end{array}$ & Forebay & 1.23 & $<0.05$ & $<0.2$ & $<0.2$ & 0.21 \\
\hline Samples & Cell 4 & 1.57 & $<0.05$ & $<0.2$ & $<0.2$ & 0.31 \\
\hline
\end{tabular}

Table 17: SWAMP water chemistry measurements from 1998/1999 observed in water samples collected in the Markham BMP during wet weather and dry weather events. Wet weather samples were collected in the summer/fall. Dry weather samples were collect in all four seasons (SWAMP, 2002).

\begin{tabular}{|c|c|c|c|c|c|c|}
\hline & Subsystem & $\begin{array}{c}\text { TKN } \\
(\mathrm{mg} / \mathrm{L})\end{array}$ & $\begin{array}{c}\text { Phosphate } \\
\text { (mg/L) }\end{array}$ & $\begin{array}{c}\mathrm{Cu} \\
(\mathrm{mg} / \mathrm{L})\end{array}$ & $\begin{array}{c}\mathrm{Zn} \\
(\mathrm{mg} / \mathrm{L})\end{array}$ & $\begin{array}{c}\text { Chloride } \\
\text { (mg/L) }\end{array}$ \\
\hline $\begin{array}{l}\text { Wet } \\
\text { Weather }\end{array}$ & Forebay Inlet & 1.79 & 0.08 & 0.017 & 0.087 & 95.6 \\
\hline Sample & Wetland Outlet & 0.82 & 0.01 & 0.008 & 0.014 & 107.9 \\
\hline $\begin{array}{l}\text { Dry } \\
\text { Weather }\end{array}$ & Fore & 0.65 & 0.02 & 0.007 & 0.025 & 269.9 \\
\hline Sample & Wetland Outlet & 0.70 & 0.01 & 0.008 & 0.009 & 121.6 \\
\hline $\begin{array}{l}\text { Wet \& Dry } \\
\text { Weather }\end{array}$ & Forebay Inlet & 1.22 & 0.05 & 0.012 & 0.056 & 182.7 \\
\hline Samples & Wetland Outlet & 0.76 & 0.01 & 0.008 & 0.011 & 114.7 \\
\hline
\end{tabular}

Table 18: Baseline water chemistry measurements from 1992/1993 observed in water samples collected in the former North Pond during wet weather and dry weather events (SWAMP, 2002).

\begin{tabular}{|l|c|r|r|r|r|r|}
\hline $\begin{array}{l}\text { Wet \& } \\
\text { Dry } \\
\text { Weather }\end{array}$ & Subsystem & $\begin{array}{c}\text { TKN } \\
(\mathbf{m g} / \mathbf{L})\end{array}$ & $\begin{array}{c}\text { Phosphate } \\
(\mathbf{m g} / \mathbf{L})\end{array}$ & $\mathbf{C u}(\mathbf{m g} / \mathbf{L})$ & \multicolumn{1}{|c|}{$\begin{array}{c}\text { Zn } \\
(\mathbf{m g} / \mathbf{L})\end{array}$} & \multicolumn{1}{c|}{$\begin{array}{c}\text { Chloride } \\
(\mathbf{m g} / \mathbf{L})\end{array}$} \\
\cline { 2 - 7 } Samples & Inlet & 1.88 & 0.04 & 0.014 & 0.069 & 54.2 \\
& Outlet & 1.66 & 0.02 & 0.010 & 0.036 & 96.4 \\
\hline
\end{tabular}


the wetland complex. The 1992/1993 TKN reductions were not as efficient as those reported in the SWAMP 2002 study (SWAMP, 2002).

Although a reduction in TKN concentrations was reported in the two previous water quality surveys, their removal efficiencies were generally poor (SWAMP, 2002). This may be attributed to that fact that Typha spp. are less effective for ammonia removal compared to other wetland plants such as Scirpus spp. (Gersberg et al., 1986; SWAMP, 2002). Perhaps this could explain the poor TKN removal performance of the wetland complex in the present study.

Different parameters were used to measure salinity concentrations within the Markham BMP and former North Pond; however, similar patterns emerge amongst the measurements obtained. According to Table 16 and Table 17, during wet weather events, salinity or chloride levels seem to increase in effluent water sampled in July 2007 and in 1998/1999. However, only the 1998/1999 survey showed a decrease in chloride levels during dry weather events (Table 16 and 17). Overall, in the present study, salinity levels in effluent waters during collective wet and dry weather events increased (Table 16), while chloride levels decreased in the 1998/1999 survey for the same events (Table 17). This increase is similar to that demonstrated in the 1992/1993 baseline survey (Table 18). Furthermore, it is interesting to note that chloride concentrations increased from 1992/1993 to 1998/1999 (Table 17 and 18). This may be attributed to the increase in urbanization and the use of road salt in the surrounding area (SWAMP, 2002). Perhaps further increases in urbanization since the 1998/1999 survey have overwhelmed the Markham BMP with saline conditions and hindered its present ability to efficiently remove this contaminant.

The potential inefficiencies at the Markham BMP may also be attributed to factors such as $\mathrm{pH}$ levels and the availability of phosphorus. For instance, the Markham BMP had an average 
water $\mathrm{pH}$ of 8.11 and an average soil $\mathrm{pH}$ of 7.77 during the July 2007 survey. These alkaline conditions may be caused by the construction activity adjacent the facility. During precipitation events, runoff containing construction debris (i.e. concrete sediments, dust, gravel etc.), enters the facility and consequently increases $\mathrm{pH}$ levels. In general, alkaline conditions can hinder nutrient uptake by plants and biological activity of microorganisms (Troeh and Thompson, 1993; Brady and Weil, 1999).

Furthermore, in urban wetlands, phosphorus has been found to be the primary limiting nutrient for plant growth (Woo and Zedler, 2002; Schooler et al., 2006). According to Table 16, the average concentration of dissolved phosphorus observed at the Markham BMP during the July 2007 survey was $<0.05 \mathrm{mg} / \mathrm{L}$. If these concentrations remain close to zero, $\mathrm{P}$ may be a limiting nutrient in the wetland complex. Thus, there may be reduced biological activity and plant growth due to $\mathrm{P}$ limitations. Therefore, both $\mathrm{pH}$ levels and the availability of phosphorus may be attributing to a decrease in the efficiency of contaminant removal in the Markham BMP.

\subsection{Management Recommendations for Constructed Stormwater Wetlands}

There are two approaches to wetland creation projects; the designer approach and the self-design/organization approach (Mitsch and Wilson, 1996; Whigham et al., 2002). The designer approach involves both introducing certain species so that the vegetation composition of the constructed wetland mimics natural wetlands and transplanting soils from natural wetlands which contain a viable seed bank (Mitsch and Wilson, 1996; Whigham et al., 2002). On the other hand, the self-design/organization approach involves allowing vegetation to establish and develop naturally in constructed wetlands (Mitsch and Wilson, 1996; Whigham et al., 2002). This is based on the assumption that through natural colonization, the appropriate vegetation 
composition will become established and resemble that of natural wetlands (Mitsch and Wilson, 1996; Whigham et al., 2002).

Both methods used in wetland creation projects are vulnerable to invasive species establishment and the development of monocultures. However, Mitsch and Wilson (1996) found that after two years, designer wetlands had higher species diversity and richness, and lower Typha spp. cover compared to self-design wetlands. Furthermore, Brown and Bedford (1997) found that soil transplantation facilitated the establishment of desirable native wetland plant species and limited Typha populations. Overall, research suggests that increases in species richness and diversity are associated with a reduction in the invasibility of an area (LindigCisneros and Zedler, 2002b).

In general, for constructed wetlands, approaches such as multi-seeding, multitransplanting, and the establishment of open water systems, will support the development of an ideal vegetation composition in created wetlands (Mitsch and Wilson, 1996). At the Markham BMP, the designer approach was utilized. For instance, seed banks from a former marsh were used to promote the establishment of vegetation. It is important to identify the composition of the seed bank being used for a constructed wetland in order to determine if it is consistent with the management goals of the site (Brown and Bedford, 1997). In spite of this, the seed bank composition used at the Markham BMP site was not specified in the SWAMP (2002) report. Water level is also an important factor in the establishment of wetland plants, since they control seed germination (Brown and Bedford, 1997). Thus, if seeds are concentrated at greater depths, than there will be a reduction in plant establishment (Brown and Bedford, 1997).

In addition to the seed bank, the introduction of seedlings was planned for the Markham BMP site (SWAMP, 2002). However, the planting program was never implemented (SWAMP, 
2002). This is unfortunate since it may have reduced the invasibility of the site. For instance, Boers et al. (2007) suggested that when plantings are not performed in stormwater wetlands, Typha spp. will colonize and species richness will be reduced.

Thus, an important recommendation for the Markham BMP and other stormwater wetlands is to restore and promote native plant species populations. Currently, invasive plant species management in constructed wetland systems focuses on removing the invasive species through intensive management techniques such as cutting, burning, and/or herbicides use (Brown and Bedford, 1997; Owen, 1999; Sheley et al., 2006). However, more attention should be focused on understanding and manipulating the ecological and/or successional processes that influence vegetation community dynamics and composition, in order to support native species populations (Sheley et al., 2006). These processes include site availability, species availability, and species performance (Sheley et al., 2006).

\subsubsection{Site Availability}

In terms of site availability, the management of stormwater wetland hydroperiods to favour native species populations should be considered (Boers et al., 2007; Jenkins and Greenway 2007). Thullen et al. (2005) suggested that increasing water depth was the most effective way to control the spread of invasive species such as Typha spp. and Phragmites australis. Constructed wetland managers must be able to manipulate water levels in order to maintain water depths within the constructed wetland that discourage certain types of vegetation establishment (Thullen et al., 2005). However, it is important to maintain appropriate water depths in some areas to promote vegetation growth and to plant desirable species in these sites (Thullen et al., 2005). One strategy for this management objective is the use of hummocks or submerged islands. Developed by Thullen et al. (2005), a hummock consists of a shallow water 
zone surrounded by a deeper water zone. The shallow zones provide sites for emergent vegetation growth, while the deep zones limit vegetation expansion (Thullen et al., 2005). Thus, this configuration maintains vegetation to open water zones that isolates plants from aggressive invasive species (Thullen et al., 2005).

The management of plant litter accumulation and decomposition should also be considered, in order to create sites for new emergent plant species to establish and develop (Thullen et al., 2005). Hummock configurations support this objective in that vegetation decomposition rates significantly increase when open water surrounds and inundates vegetation (Thullen et al., 2005). This can be attributed to several factors including: improved contact between vegetation and various macroinvertebrates, fungi, and bacteria communities; the creation of desirable macroinvertebrate habitat; and higher DO levels associated with open water zones (Thullen et al., 2005).

It is also interesting to note that the hummock configuration provides optimal habitat for wildlife such as wetland birds (Knight, 1997; Thullen et al., 2005). Dense monocultures of invasive species, such as Typha spp. or Phragmites australis, are often associated with poor habitat quality and low animal diversity (Knight, 1997; Bonilla-Warford and Zedler, 2002). For instance, wetland birds will either avoid or delay nesting in these invaded habitats (Maddox and Wiedenmann, 2005).

At present, the Markham BMP constructed wetland facility is designed to reduce any potential limitations to wildlife (Sutula and Stein, 2003). Stormwater runoff first flows through the sediment forebay, followed by the wet pond, before entering the wetland complex. As stormwater runoff flows through these system components, the water undergoes treatment. 
Thus, pre-treated water then enters the wetland complex, which potentially reduces wildlife exposure to contaminants (Sutula and Stein, 2003).

\subsubsection{Species Availability and Species Performance}

In terms of species availability and performance, it is important for constructed wetland managers to introduce and promote native plant species in constructed stormwater wetlands. This would be especially beneficial if the hummock configuration was utilized as native plants could be introduced in shallow water zones (Thullen et al., 2005). Boer et al. (2007) recommended increasing native vegetation communities since these plants have the ability to foster diversity by encouraging the growth of additional native species. Increased plant diversity in stormwater wetlands will promote improvements in water quality functions, add habitat value for wildlife, and create recreational opportunities for the public (Bonilla-Warford and Zedler, 2002). Recreational activities such as hiking, jogging, biking, and bird-watching, are the primary human uses of stormwater wetlands (Knight, 1997). Along the wetland complex of the Markham BMP, there were trails for the public to use that allowed them to enjoy the wetland habitat and associated wildlife. While conducting field work, red-winged blackbirds, Canadian geese, and night herons were often spotted in and around the wetland complex. This site was even utilized by rare native trumpeter swans, a protected species in Ontario. Thus, stormwater wetlands, such as the Markham BMP, hold great potential for the development of viable wildlife habitat and public recreation within an urban environment.

However, introducing the appropriate native species is vital. Native vegetation must be able to tolerate the stresses associated with stormwater wetlands and should be able to effectively compete with invasive species (Bonilla-Warford and Zedler, 2002; Boers et al., 2007). 
Overall, there are several characteristics that the ideal plant for stormwater wetlands should possess. The plant should be robust, perennial, easy to propagate, have dense roots and rhizomes, tolerate flashy hydroperiods, and above all be native to the region in which the wetland is situated (Bonilla-Warford and Zedler, 2002). However, managers often select plant species (i.e. Typha spp., Phragmites australis, Scirpus spp., Juncus spp. and Phalaris arundinacea) that fall short of this ideal (Bonilla-Warford and Zedler, 2002; Sutula and Stein, 2003). The problem stems from limited knowledge and understanding of plant tolerances to water levels, water chemistry, and soil types (Owen, 1999; Bonilla-Warford and Zedler, 2002; Jenkins and Greenway 2007). Since plant tolerances in constructed wetlands are only understood for a few species, greater priority should be placed on further research in this area (Owen, 1999; Bonilla-Warford and Zedler, 2002; Jenkins and Greenway 2007).

In general, for those designing and constructing stormwater wetlands, vegetation is usually one of the last aspects taken into consideration (Thullen et al., 2005). Furthermore, once a stormwater wetland is in operation, vegetation management is perceived as costly and a nuisance by constructed wetland managers (Thullen et al., 2005). However, vegetation management must become a priority since plants affect important constructed stormwater wetland features such as treatment functions, wildlife habitat, and public recreational activities. Artificial control strategies, such as chemical or mechanical methods of vegetation management, are intensive and could pose direct or indirect environmental risks. Thus, the key is to incorporate natural control strategies into a stormwater wetland system by manipulating ecological and/or successional processes that influence emergent plant community dynamics and composition. This is a more suitable option that is less damaging to the environment and more cost efficient over the long-term (Thullen et al., 2005). If desired, native plant species can 
become well established and abundant in constructed stormwater wetlands, increasing the potential to reduce the invasibility and dominance of invasive plants in the system (Thullen $e t$ al., 2005).

\subsection{Summary of Important Conclusions}

Vegetation surveys conducted at the Markham BMP found the vegetation community of the wetland complex was composed of four emergent plant species: T. angustifolia, T. latifolia, P. arundinacea, and S. tabernaemontani. Thus, there was an overall lack of biodiversity within the wetland complex. Furthermore, since the SWAMP (2002) study, this site has been transformed towards invasiveness, as species such as T. angustifolia dominate all four cells of the wetland complex.

In general, the Efficient Use Hypothesis and the Broader Tolerance Hypothesis suggest that vegetation composition and abundance is a function of interspecific competition between plant species and environmental factors respectively (Wetzel and van der Valk, 1998; Zedler and Kercher, 2004). In terms of interspecific competition, increases in invasive species abundance were associated with a reduction in native species abundance. Competitive interactions between T. angustifolia and T. latifolia, or P. arundinacea and Typha spp. are just some of the possible interspecific relationships occurring in the wetland complex of the Markham BMP. For instance, T. angustifolia may be competitively superior to T. latifolia (Weisner, 1993). Moreover, Typha spp. may be out-competing $P$. arundinacea (a light sensitive species) for light resources (Klimesova, 1994; Lindig-Cisneros and Zedler, 2001; Adams and Galatowitsch, 2005).

When assessing potential relationships between vegetation abundance and environmental factors, few environmental determinants for vegetation abundance were found. Overall, invasive species stem density was positively correlated with $\mathrm{NH}_{4}-\mathrm{N}(P<0.05)$ and $T$. angustifolia stem 
density was positively correlated with both TDS $(P<0.05)$ and salinity $(P<0.05)$. Moreover, despite the significant differences in soil chemistry variables for Cell 4 , vegetation composition and abundance were consistently dominated by $T$. angustifolia in all cells of the wetland complex.

Compared to the situation described in the SWAMP (2002) study, the present wetland complex may not be functioning efficiently in terms of water quality improvements, especially for parameters such as TKN and salinity. An analysis of water samples collected for the present study demonstrated an increase in TKN levels by the time water reached Cell 4 of the wetland complex. In fact, the TKN concentrations in effluent waters are similar to those reported in a 1992/1993 baseline survey (SWAMP, 2002). In contrast, the SWAMP (2002) study reported an overall reduction in TKN concentrations in effluent water during wet and dry weather events, although removal efficiency was generally poor (SWAMP, 2002).

Despite the capacity for TKN removal in past assessments, both the present study and the SWAMP (2002) study demonstrated an increase in salinity or chloride concentrations in effluent water of the Markham BMP during wet weather events. However, only the SWAMP (2002) study reported a decrease in chloride levels during dry weather events. According to the July 2007 survey, salinity levels in effluent waters during collective wet and dry weather events increase; however, in the past, chloride levels were shown to decrease for the same collective events (SWAMP, 2002). Furthermore, at present there seem to be no significant differences in water chemistry values between the vegetated and non-vegetated subsystems of the constructed wetland. This also suggests the wetland complex may not be functioning efficiently in terms of water quality improvements. 
Long-term monitoring is needed at the Markham BMP in order to ensure this facility is performing properly. In general, most constructed wetland monitoring occurs right after construction is complete (Sutula and Stein, 2003). It usually consists of a single study and provides a limited snapshot of the conditions of the system (Sutula and Stein, 2003). However, stormwater wetland vegetation and water quality functioning can change dramatically in a short period of time (Sutula and Stein, 2003). Thus, long-term monitoring can help constructed wetland managers identify potential problems, improve performance, and enhance the habitat value of stormwater wetlands (Sutula and Stein, 2003). Baseline monitoring of inflow volume, retention time, inflow/outflow water quality, sediment contamination, and vegetation communities are all recommended (Sutula and Stein, 2003).

Overall, it is essential for constructed wetland managers to improve their understanding of invasive species and their relationship to and impact on vegetation composition and abundance within constructed stormwater wetlands. This will enable them to make informed and timely management decisions regarding the design, performance, and maintenance of vegetation communities within constructed stormwater wetlands. It also facilities the development of practical and well-organized planting strategies for future endeavours. In general, reducing invasive plant communities and increasing native plant diversity should be promoted. This is believed improve the effectiveness and efficiency of processes and functions in constructed wetlands, thus enhancing the benefits and value of these facilities. 


\section{Appendices}

\section{Appendix A: Evaluation of the relationships between environmental variables and species abundance at the Markham BMP site using multiple regression analysis.}

To supplement the correlation analyses conducted in this study, multiple regression was also used to assess the relationships between species abundance (i.e. stem density and biomass) and environmental variables (i.e. soil and water chemistry parameters).

Before conducting the multiple regressions, it was necessary to identify any potential problem with multicollinearity (Morgan et al., 2005). An evaluation of correlations among the environmental variables was performed in order to determine which variables were significantly intercorrelated (Morgan et al., 2005). Highly correlated variables $(r>0.5, P<0.05)$ were not used together in the multiple regressions (Morgan et al., 2005). All possible combinations of uncorrelated variables for soil chemistry and water chemistry were determined and these sets were used in the multiple regression analysis.

Few environmental determinants for vegetation abundance were found significant. There were no significant relationships observed in multiple regression analysis between various sets of water chemistry parameters and species abundance for Typha angustifolia, Phalaris arundinacea, and Typha latifolia. In terms of soil chemistry parameters and species abundance, a significant relationship $(P<0.05)$ was observed with only one set of variables. Together $\mathrm{NH}_{4}-\mathrm{N}$ and $\mathrm{NO}_{3}-\mathrm{N}$ were found to be significantly associated with $P$. arundinacea stem density $\left(F_{0.05,2,5}=6.084, P=0.046\right)$. The equation produced by this multiple regression is:

$$
\mathrm{y}=55.803-1.241 \mathrm{x}_{1}-33.062 \mathrm{x}_{2}
$$

where y represents $P$. arundinacea stem density, $\mathrm{x}_{1}$ represents $\mathrm{NH}_{4}-\mathrm{N}$ concentrations, and $\mathrm{x}_{2}$ represents $\mathrm{NO}_{3}-\mathrm{N}$ concentrations. According to this equation, the direction of the relationship is 
negative, implying that $P$. arundinacea stem density decreases with increasing $\mathrm{NH}_{4}-\mathrm{N}$ and $\mathrm{NO}_{3}$ $\mathrm{N}$ concentrations in the soil. The adjusted $\mathrm{R}^{2}$ value for this regression was 0.592 Tolerance values for this regression were checked for any remaining problems with multicollinearity. If tolerance values are low $\left(<1-\mathrm{R}^{2}\right)$ then there is still an issue with multicollinearity (Morgan et al., 2005). However, if tolerance values are high $\left(>1-R^{2}\right)$ then there is no problem with multicollinearity (Morgan et al., 2005). For this regression, tolerance values were 0.914 which is much greater than the 0.408 or $1-\mathrm{R}^{2}$ threshold.

$P$. arundinacea must contend with interspecific competition for resources by other plant species at the Markham BMP site. T. angustifolia was the dominant emergent plant species, forming a virtual monoculture at this site. T. angustfolia may be responding better to the higher nutrient conditions at the site which results in the negative relationship for $P$. arundinacea. 
Appendix B: Raw data values for soil chemistry variables observed in soil samples collected in each of the four wetland cells at the Markham BMP site in July 2007.

\begin{tabular}{|c|c|c|c|c|c|c|c|c|c|}
\hline Date & Cell & $\begin{array}{c}\text { Plot } \\
\text { ID }\end{array}$ & $\begin{array}{c}\mathrm{NH}_{4}-\mathrm{N} \\
(\mathrm{mg} / \mathrm{kg} \\
\mathrm{dry})\end{array}$ & $\begin{array}{c}\mathrm{NO}_{3}-\mathrm{N} \\
(\mathrm{mg} / \mathrm{kg} \\
\mathrm{dry})\end{array}$ & $\begin{array}{c}\text { Soil Organic } \\
\text { Matter (\% } \\
\text { dry) }\end{array}$ & $\begin{array}{l}\text { Soil } \\
\text { pH }\end{array}$ & $\begin{array}{c}\text { Plant } \\
\text { Available P } \\
\text { (mg/L soil) }\end{array}$ & $\begin{array}{c}\text { Plant } \\
\text { Available K } \\
\text { (mg/L soil) }\end{array}$ & $\begin{array}{c}\text { Plant } \\
\text { Available Mg } \\
\text { (mg/L soil) }\end{array}$ \\
\hline \multirow[t]{3}{*}{ 3-Jul-07 } & \multirow[t]{3}{*}{1} & $\mathrm{~A} 1$ & 45.000 & 0.193 & 10.4 & 7.6 & 18 & 90 & 170 \\
\hline & & $\mathrm{A} 2$ & 26.200 & 0.000 & 10.4 & 7.6 & 16 & 78 & 157 \\
\hline & & A3 & 73.800 & 0.053 & 13.8 & 7.5 & 23 & 95 & 117 \\
\hline \multirow[t]{3}{*}{ 5-Jul-07 } & \multirow[t]{3}{*}{1} & B1 & 3.000 & 0.107 & 2.4 & 7.9 & 17 & 80 & 109 \\
\hline & & B2 & 4.290 & 0.594 & 1.8 & 7.8 & 12 & 50 & 109 \\
\hline & & B3 & 22.900 & 0.000 & 2.6 & 7.9 & 18 & 69 & 108 \\
\hline \multirow[t]{6}{*}{ 6-Jul-07 } & \multirow[t]{3}{*}{3} & E1 & 109.000 & 0.000 & 8.5 & 7.7 & 37 & 97 & 153 \\
\hline & & $\mathrm{E} 2$ & 70.100 & 0.000 & 14.8 & 7.6 & 26 & 46 & 114 \\
\hline & & E3 & 103.000 & 0.248 & 5.2 & 7.8 & 36 & 93 & 136 \\
\hline & \multirow[t]{3}{*}{3} & $\mathrm{~F} 1$ & 50.100 & 0.258 & 8.2 & 7.6 & 20 & 84 & 163 \\
\hline & & $\mathrm{F} 2$ & 9.710 & 0.170 & 3.0 & 7.7 & 14 & 51 & 132 \\
\hline & & F3 & 50.100 & 0.486 & 5.0 & 7.7 & 22 & 57 & 102 \\
\hline \multirow[t]{6}{*}{ 10-Jul-07 } & \multirow[t]{6}{*}{2} & D1 & 12.400 & 0.655 & 3.4 & 7.9 & 16 & 63 & 115 \\
\hline & & D2 & 26.600 & 0.279 & 4.9 & 7.8 & 27 & 75 & 130 \\
\hline & & D3 & 11.400 & 0.063 & 3.8 & 7.8 & 17 & 63 & 112 \\
\hline & & D4 & 19.100 & 0.000 & 6.7 & 7.8 & 24 & 100 & 178 \\
\hline & & D5 & 10.800 & 0.748 & 4.2 & 7.8 & 24 & 95 & 139 \\
\hline & & D6 & 16.600 & 0.000 & 5.9 & 7.7 & 23 & 113 & 154 \\
\hline \multirow[t]{6}{*}{ 12-Jul-07 } & \multirow[t]{6}{*}{2} & $\mathrm{C} 1$ & 2.670 & 0.052 & 5.5 & 7.8 & 20 & 59 & 147 \\
\hline & & $\mathrm{C} 2$ & 20.500 & 0.097 & 7.7 & 7.8 & 31 & 81 & 170 \\
\hline & & C3 & 11.100 & 0.000 & 9.2 & 7.6 & 29 & 60 & 133 \\
\hline & & $\mathrm{C} 4$ & 11.000 & 0.000 & 8.2 & 7.7 & 25 & 83 & 196 \\
\hline & & C5 & 8.810 & 0.000 & 8.4 & 7.7 & 30 & 67 & 133 \\
\hline & & C6 & 9.570 & 0.000 & 8.2 & 7.5 & 25 & 58 & 130 \\
\hline \multirow[t]{6}{*}{ 17-Jul-07 } & \multirow[t]{6}{*}{4} & $\mathrm{H} 1$ & 1.180 & 0.187 & 8.2 & 7.8 & 15 & 71 & 149 \\
\hline & & H2 & 5.870 & 0.181 & 4.1 & 7.8 & 15 & 63 & 105 \\
\hline & & H3 & 2.810 & 0.080 & 8.4 & 7.6 & 13 & 51 & 88 \\
\hline & & $\mathrm{H} 4$ & 39.600 & 0.696 & 1.0 & 7.9 & 11 & 66 & 101 \\
\hline & & H5 & 2.390 & 0.185 & 1.0 & 7.8 & 7 & 26 & 59 \\
\hline & & H6 & 15.700 & 0.758 & 1.9 & 7.8 & 8 & 31 & 75 \\
\hline \multirow[t]{6}{*}{ 18-Jul-07 } & \multirow[t]{6}{*}{4} & G1 & 0.571 & 0.739 & 0.8 & 8.0 & 8 & 46 & 94 \\
\hline & & G2 & 7.440 & 0.544 & 0.9 & 7.9 & 8 & 47 & 91 \\
\hline & & G3 & 0.953 & 0.245 & 1.4 & 7.9 & 12 & 49 & 98 \\
\hline & & G4 & 0.463 & 0.064 & 0.3 & 8.0 & 5 & 38 & 81 \\
\hline & & G5 & 0.150 & 1.410 & 1.3 & 8.0 & 9 & 48 & 104 \\
\hline & & G6 & 3.030 & 0.658 & 1.7 & 8.0 & 11 & 52 & 93 \\
\hline
\end{tabular}


Appendix C: Raw data values for water chemistry variables observed in water samples collected in each subsystem at the Markham BMP site in July 2007.

\begin{tabular}{|c|c|c|c|c|c|c|c|c|c|}
\hline Date & Subsystem & $\begin{array}{c}\text { TKN } \\
(\mathrm{mg} / \mathrm{L})\end{array}$ & $\begin{array}{l}\text { Dissolved } \\
\text { P (mg/L) } \\
\end{array}$ & $\underset{(\mathrm{mg} / \mathrm{L})}{\mathrm{Cu}}$ & $\begin{array}{c}\mathbf{Z n} \\
(\mathbf{m g} / \mathbf{L})\end{array}$ & $\begin{array}{c}\text { Water } \\
\text { pH }\end{array}$ & $\begin{array}{c}\text { DO \% } \\
\text { saturation }\end{array}$ & $\begin{array}{c}\text { TDS } \\
\text { (ppm) }\end{array}$ & $\begin{array}{c}\text { Salinity } \\
\text { (PSU) }\end{array}$ \\
\hline \multirow[t]{2}{*}{ 20-Jul-07 } & Forebay & 1.26 & $<0.05$ & $<0.2$ & $<0.2$ & 8.19 & 53.4 & 152 & 0.14 \\
\hline & Wet Pond & 1.22 & $<0.05$ & $<0.2$ & $<0.2$ & 7.93 & 67.3 & 326 & 0.32 \\
\hline Wet & Cell 1 & 1.37 & 0.058 & $<0.2$ & $<0.2$ & 7.90 & 62.9 & 343 & 0.33 \\
\hline Weather & Cell 2 & 1.41 & $<0.05$ & $<0.2$ & $<0.2$ & 7.78 & 57.8 & 343 & 0.34 \\
\hline \multirow[t]{2}{*}{ Sample } & Cell 3 & 1.23 & $<0.05$ & $<0.2$ & $<0.2$ & 7.63 & 39.9 & 352 & 0.34 \\
\hline & Cell 4 & 1.46 & $<0.05$ & $<0.2$ & $<0.2$ & 7.70 & 50.8 & 348 & 0.34 \\
\hline \multirow[t]{2}{*}{ 22-Jul-07 } & Forebay & 1.35 & 0.095 & $<0.2$ & $<0.2$ & 8.18 & 66.8 & 180 & 0.17 \\
\hline & Wet Pond & 1.07 & $<0.05$ & $<0.2$ & $<0.2$ & 8.40 & 97.3 & 300 & 0.29 \\
\hline Dry & Cell 1 & 1.27 & $<0.05$ & $<0.2$ & $<0.2$ & 7.68 & 61.5 & 309 & 0.30 \\
\hline Weather & Cell 2 & 1.40 & $<0.05$ & $<0.2$ & $<0.2$ & 7.92 & 88.7 & 302 & 0.29 \\
\hline \multirow[t]{2}{*}{ Sample } & Cell 3 & 1.14 & $<0.05$ & $<0.2$ & $<0.2$ & 8.04 & 103.1 & 309 & 0.30 \\
\hline & Cell 4 & 1.16 & $<0.05$ & $<0.2$ & $<0.2$ & 7.72 & 84.9 & 315 & 0.31 \\
\hline \multirow[t]{2}{*}{ 31-Jul-07 } & Forebay & 1.07 & $<0.05$ & $<0.2$ & $<0.2$ & 8.63 & 155.5 & 323 & 0.31 \\
\hline & Wet Pond & 1.13 & $<0.05$ & $<0.2$ & $<0.2$ & 9.00 & 149.7 & 266 & 0.25 \\
\hline Dry & Cell 1 & 1.34 & $<0.05$ & $<0.2$ & $<0.2$ & 8.47 & 111.2 & 282 & 0.27 \\
\hline Weather & Cell 2 & 1.42 & $<0.05$ & $<0.2$ & $<0.2$ & 8.27 & 96.5 & 282 & 0.27 \\
\hline \multirow[t]{2}{*}{ Sample } & Cell 3 & 1.80 & 0.092 & $<0.2$ & $<0.2$ & 8.05 & 89.0 & 312 & 0.30 \\
\hline & Cell 4 & 2.09 & $<0.05$ & $<0.2$ & $<0.2$ & 8.43 & 85.2 & 294 & 0.28 \\
\hline
\end{tabular}




\section{References}

Adams, R., and Galatowitsch, S.M. (2005). Phalaris arundinacea (reed canary grass): Rapid growth and growth pattern in conditions approximating newly restored wetlands. Ecoscience, 12(4), 569-573.

Anderson, E., Hellekson, D., Merickel, J., Wilson, G., Wilson. M., and Bonick, C. (2001). Minnesota Urban Small Sites BMP Manual. St. Paul, MN: Metropolitan Council Environmental Services.

Angeloni, N.L., Jankowski, K.J., Tuchman, N.C., and Kelly, J.J. (2006). Effects of an invasive cattail species (Typha $x$ glauca) on sediment nitrogen and microbial community composition in a freshwater wetland. FEMS Microbiology Letters, 263, 86-92.

Boers A.M., Veltman, R.L.D., and Zedler, J.B. (2007). Typha $\times$ glauca dominance and extended hydroperiod constrain restoration of wetland diversity. Ecological Engineering, 29, 232244.

Bonilla-Warford, C.M., and Zedler, J.B. (2002). Potential for using native plant species in stormwater wetlands. Environmental Management, 29(3), 385-394.

Borin, M., Bonaiti, G., and Giardini, L. (2001). Controlled drainage and wetlands to reduce agricultural pollution: A Lysimetric Study. Journal of Environmental Quality, 30, 13301340.

Brady, N.C., and Weil, R.R. (1999). The Nature and Properties of Soils $\left(12^{\text {th }}\right.$ ed.). New Jersey: Prentice Hall.

Brix, H. (1994). Use of constructed wetlands in water pollution control: Historical development, present status and future perspectives. Water Science Technology, 30(8): 209-223.

Brix, H., Dyhr-Jensen, K., and Lorenzen, B. (2002). Root-zone acidity and nitrogen source affects Typha latifolia L. growth and uptake kinetics of ammonium and nitrate. Journal of Experimental Botany, 53(379), 2441-2450.

Brown, D.S., Kreissl, J.F., Gearheart, R.A., Kruzic, A.P., Boyle, W.C., and Otis, R.J. (1999). Constructed Wetlands Treatment of Municipal Wastewaters. Washington, D.C.: U.S. Environmental Protection Agency.

Brown, S.C., and Bedford, B.L. (1997). Restoration of wetland vegetation with transplanted wetland soil: an experimental study. Wetlands, 17(3), 424-437.

Cole, C.A., Brooks, R.P., and Wardrop, D.H. (2001). Assessing the relationship between biomass and soil organic matter in created wetlands of central Pennsylvania, USA. Ecological Engineering, 17, 423-428. 
Cox, D.D. (2002). A Naturalist's Guide to Wetland Plants: An Ecology for Eastern North America. Syracuse, New York: Syracuse University Press.

Cronk, J.K., and Fennessy, M.S. (2001). Wetland Plants Biology and Ecology. Boca Raton, Florida: Lewis Publishers.

Crow, G.E. and Hellquist, C.B. (2000). Aquatic and Wetland Plants of Northeastern North America (Vols. 1-2). Madison, WI: University of Wisconsin Press.

Davis, L. (2000). A Handbook of Constructed Wetlands: General Considerations Vol. 1. Washington, D.C.: U.S. Government Printing Office.

Dyhr-Jensen, K., and Brix, H. (1996). Effects of $\mathrm{pH}$ on ammonium uptake by Typha latifolia L. Plant Cell and Environment, 19, 1431-1436.

Ehrenfeld, J.G., and Schneider, J.P. (1991). Chamaecyparis thyoides wetlands and suburbanization: effects on hydrology, water quality and plant community composition. Journal of Applied Ecology, 28(2), 467-490.

Fickbohm, S.S., and Zhu, W. (2006). Exotic purple loosestrife invasion of native cattail freshwater wetlands: Effects on organic matter distribution and soil nitrogen cycling. Applied Soil Ecology, 32, 123-131.

Findlay, S., Howe, K., and Austin, H.K. (1990). Comparison of detritus dynamics in two tidal freshwater wetlands. Ecology, 71(1), 288-295.

Galatowitsch, S.M., Anderson, N.O., and Ascher, P.D. (1999). Invasiveness in wetland plants in temperate North America. Wetlands 19, 733-755.

Gaudet, C.L., and Keddy, P.A. (1995). Competitive performance and species distribution in shortline plant communities: a comparative approach. Ecology, 76(1), 280-291.

Gearheart, R., Finney, B., Lang, M., Anderson, J., and Lagace, S. (1999). Free Water Surface Wetlands for Wastewater Treatment: A Technology Assessment. Washington, D.C: U.S. Environmental Protection Agency.

Gersberg, R.M., Elkins, B.V., Lyon, S.R., and Goldman, C.R. (1986). Role of aquatic plants in wastewater treatment by artificial wetlands. Water Research, 69(6), 363-368.

Google Earth Pro [computer software]. (2008). California: Google Inc.

Goslee, S.C., Brooks, R.P., and Cole, C.A. (1997). Plants as indicators of wetland water source. Plant Ecology, 131, 199-206. 
Grace, J.B. (1988). The effects of nutrient additions on mixtures of Typha latifolia L. and Typha domingensis Pres. along a water-depth gradient. Aquatic Botany, 31, 83-92.

Grace, J.B., and Harrison, J.S. (1986). The biology of Canadian weeds. 73. Typha latifolia L., Typha angustifolia L., and Typha x glauca Godr. Canadian Journal of Plant Science, 66, 361-379.

Grace J.B., and Wetzel R.G. (1981). Habitat partitioning and competitive displacement in cattails (Typha): experimental field studies. American Naturalist, 118, 463-474.

Grace, J.B., and Wetzel, R.G. (1998). Long-term dynamics of Typha populations. Aquatic Botany, 61, 137-146.

Green, E.K., and Galatowitsch, S.M. (2002). Effects of Phalaris arundinacea and nitrate-N addition on the establishment of wetland plant communities. Journal of Applied Ecology, $39,134-144$.

Hager, H.A., and Vinebrooke, R.D. (2004). Positive relationships between invasive purple loosestrife (Lythrum salicaria) and plant species diversity and abundance in Minnesota wetlands. Canadian Journal of Botany, 82, 763-773.

Helfield, J.M., and Diamond, M.L. (1997). Use of constructed wetlands for urban stream restoration: a critical analysis. Environmental Management, 21(3), 329-341.

Hench, K.R., Bissonnette, G.K., Sexstone. A.J., Coleman, J.G., Garbutt, K., and Skousen, J.G. (2003). Fate of physical, chemical, and microbial contaminants in domestic wastewater following treatment by small constructed wetlands. Water Research, 37, 921-927.

Houlahan, J.E., Keddy, P.A., Makkay, K., and Findlay, C.S. (2006). The effects of adjacent land use on wetland species richness and community composition. Wetlands, 26(1), 79-96.

Howard, R.J., and Mendelssohn, I.A. (1999). Salinity as a constraint on growth of oligohaline marsh macrophytes. II. Salt pulses and recovery potential. American Journal of Botany, 86(6), 795-806.

Jenkins, G.A. and Greenway, M. (2007). Restoration of a constructed wetland to improve its ecological and hydrological performance. Water Science and Technology, 56(11), 109116.

Kasper, T. M., and Jenkins, G. A. (2007). Measuring the background concentration in a constructed stormwater treatment wetland. Urban Water Journal, 4(2), 79-91.

Kennedy, G., and Mayer, T. (2002). Natural and constructed wetlands in Canada: an overview. Water Quality Research Journal of Canada, 37(2), 295-325. 
Kercher, S.M., and Zedler, J.B. (2004a). Flood tolerance in wetland angiosperms: a comparison of invasive and noninvasive species. Aquatic Botany, 80, 89-102.

Kercher, S.M., and Zedler, J.B. (2004b). Multiple disturbances accelerate invasion of reed canary grass (Phalaris arundinacea L.) in a mesocosm study. Oecologia, 138, 455-464.

Kercher, S.M., Carpenter, Q.J., and Zedler, J.B. (2004). Interrelationships of hydrologic disturbance, reed canary grass (Phalaris arundinacea L.), and native plants in Wisconsin wet meadows. Natural Areas Journal 24, 316-325.

Klimesova, J. (1994). The effects of timing and duration of floods on growth of young plants of Phalaris arundinacea L. and Urtica dioica L.: an experimental study. Aquatic Botany, 48, 21-29.

Knight, R.L. (1997). Wildlife habitat and public use benefits of treatment wetlands. Water Science Technology, 35(5), 35-43.

Knight, R.L., Clarke, Jr, R.A., and Bastian, R.K. (2001). Surface flow (SF) treatment wetlands as a habitat for wildlife and humans. Water Science and Technology, 44(11-12), 27-37.

Kuehn, M.M., and White, B.N. (1999). Morphological analysis of genetically identified cattails Typha latifolia, Typha angustifolia and Typhaxglauca. Canadian Journal of Botany, 77, 906-912.

Latham, P.J., Pearlstine, L.G., Kitchens, W.M. (1991). Spatial distributions of the softstem bulrush, Scirpus validus, across a salinity gradient. Estuaries, 14(2), 192-198.

Lindig-Cisneros, R. A., and Zedler, J. B. (2001). Effect of light on Phalaris arundinacea L. germination. Plant Ecology, 155, 75-78.

Lindig-Cisneros, R., and Zedler, J. B. (2002a). Phalaris arundinacea L. seedling establishment: effects of canopy complexity in fen, mesocosm and restoration experiments. Canadian Journal of Botany, 80, 617-624.

Lindig-Cisneros, R., and Zedler, J.B. (2002b). Relationships between canopy complexity and germination microsites for Phalaris arundinacea L. Oecologia, 133, 159-167.

Maddox, J.D., and Wiedenmann, R.N. (2005). Nesting of birds in wetlands containing Purple Loosestrife (Lythrum salicaria) and Cattail (Typha spp.). Natural Areas Journal, 25(4), 369-373.

Magee, T.K., Ernst, T.L., Kentula, M.E., and Dwire, K.A. (1999). Floristic comparison of freshwater wetlands in an urbanizing environment. Wetlands, 19(3), 517-534. 
Mahaney, W.M., Wardrop, D.H., and Brooks, R.P. (2004). Impacts of sedimentation and nitrogen enrichment on wetland plant community development. Plant Ecology, 175, 227 243.

Matsui, T., and Tsuchiya, T. (2006). Root aerobic respiration and growth characteristics of three Typha species in response to hypoxia. Ecological Research, 21, 470-475.

Maurer, D.A., and Zedler, J.B. (2002). Differential invasion of a wetland grass explained by tests of nutrients and light availability on establishment and clonal growth. Oecologia, 131, 279-288.

Miklovic, S., and Galatowitsch, S.M. (2005). Effect of $\mathrm{NaCl}$ and Typha angustifolia $\mathrm{L}$. on marsh community establishment: a greenhouse study. Wetlands, 25(2), 420-429.

Ministry of the Environment and Energy (MOEE). (1994). Water Management: Policies, Guidelines, Provincial Water Quality Objectives. Toronto, ON: Author.

Mircosoft (MS) Excel [computer software]. (2003). Redmond, Washington: Microsoft Corp.

Mitsch, W.J., and Gosselink, J.G. (2000). Wetlands (3rd ed). New York: John Wiley \& Sons Inc.

Mitsch, W.J., and Wilson, R.F. (1996). Improving the Success of Wetland Creation and Restoration with Know-How, Time, and Self-Design. Ecological Applications, 6(1), 7783.

Morgan, G.A., Leech, N.L., Gloeckner, G.W., and Barrett, K.C. (2004). SPSS for Introductory Statistics: Use and Interpretation ( $2^{\text {nd }}$ ed.). Mahwah, New Jersey: Lawrence Erlbaum Associates, Publishers.

Morgan, G.A., Leech, N.L., Gloeckner, G.W., and Barrett, K.C. (2005). SPSS for Intermediate Statistics: Use and Interpretation ( $2^{\text {nd }}$ ed.). Mahwah, New Jersey: Lawrence Erlbaum Associates, Publishers.

Morrison, S.L., and Molofsky, J. (1998). Effects of genotypes, soil moisture, and competition on the growth of an invasive grass, Phalaris arundinacea (reed canary grass). Canadian Journal of Botany, 76, 1939-1946.

National Research Council [Committee on Characterization of Wetlands]. (1995). Wetlands: Characteristics and Boundaries. Washington, D.C.: National Academy Press.

Natural Resource Conservation Center (NRCS). (2006a). Plant Guide: Broadleaved Cattail, Typha latifolia L. Washington D.C.: United States Department of Agriculture.

Natural Resource Conservation Center (NRCS). (2006b). Plant Guide: Narrowleaf Cattail, Typha angustifolia L. Washington D.C.: United States Department of Agriculture. 
Natural Resource Conservation Center (NRCS). (2006c). Plant Guide: Reed Canary Grass, Phalaris arundinacea L. Washington D.C.: United States Department of Agriculture.

Natural Resource Conservation Center (NRCS). (2006d). Plant Guide: Softstem bulrush, Schoenoplectus tabernaemontani (K.C. Gmel.) Palla. Washington D.C.: United States Department of Agriculture.

Nicholson, B.J. (1995). The wetlands of Elk Island National Park: Vegetation classification, water chemistry, and hydrotopographic relationships. Wetlands, 15(2), 119-133.

Owen, C. R. (1999). Hydrology and history: land use changes and ecological responses in an urban wetland. Wetlands Ecology and Management, 6, 209-219.

Panno, S. V., Cartwright, K., Hensel, B.R., Krapac, I.G., and Nuzzo, V.A. (1999). Impact of urban development on the chemical composition of ground water in a fen-wetland complex. Wetlands, 19, 236-245.

Perry, L.G., and Galatowitsch, S.M. (2003). A test of two annual cover crops for controlling Phalaris arundinacea invasion in restored sedge meadow wetlands. Restoration Ecology, 11(3), 297-307.

Reed, S.C. (1993). Subsurface Flow Constructed Wetlands for Wastewater Treatment: A Technology Assessment. Washington, D.C: U.S. Environmental Protection Agency.

Ribaudo, M.O. (1989). Targeting the conservation reserve program to maximize water quality benefits. Land Economics, 65(4), 320-332.

Scholz, M. (2006). Wetland Systems Control Urban Runoff. Amsterdam: Elsevier Publications.

Schooler, S.S., McEvoy, P.B., and Coombs, E.M. (2006). Negative per capita effects of purple loosestrife and reed canary grass on plant diversity of wetland communities. Diversity and Distributions, 12, 351-363

Selbo, S.M., and Allison A. Snow, A.A. (2004). The potential for hybridization between Typha angustifolia and Typha latifolia in a constructed wetland. Aquatic Botany, 78, 361-369.

Sheley, R.L., Mangold, J.M., and Anderson, J.L. (2006). Potential for successional theory to guide restoration of invasive plant dominated rangeland. Ecological Monographs, 76(3), 365-379.

Shutes, R.B.E., Revitt, D.M., Munger, A.S., and Scholes, L.N.L. (1997). The design of wetland systems for the treatment of urban runoff. Water Science Technology, 35(5), 19-25. 
Smith, L.G., Carlisle, T.J., and Meek, S.N. (1993). Implementing sustainability: the use of natural channel design and artificial wetlands for stormwater management. Journal of Environmental Management, 37, 241-257.

Spellman, F.R. (1999). The Science of Environmental Pollution. Lancaster, Pennsylvania: Technomic Publications.

SPSS 13.0 [computer software]. (2004). Chicago: SPSS Inc.

Startin, J., and Lansdown, R.V. 1994. Drainage from highways and other paved areas: methods of collection, disposal and treatment. Water and Environment Journal, 8(5), 518-526.

Stormwater Assessment Monitoring and Performance (SWAMP) Program. (2002). Performance Assessment of a Pond-Wetland Stormwater Management Facility Markham, Ontario. Downsview, ON: Toronto and Region Conservation Authority.

Stottmeister, U., Wießner, A., Kuschk, P., Kappelmeyer, U., Kastner, M., Bederski, O., Muller, R.A., and Moormann, H. (2003). Effects of plants and microorganisms in constructed wetlands for wastewater treatment. Biotechnology Advances, 22: 93- 117.

Sutula, M., and Stein, E. (2003). Habitat Value of Constructed and Natural Wetlands Used to Treat Urban Runoff: A Literature Review. California: Southern California Coastal Water Research Project.

Svengsouk, L.J., and Mitsch, W.J. (2001). Dynamics of mixtures of Typha latifolia and Schoenoplectus tabernaemontani in nutrient- enrichment wetland experiments. American Midland Naturalist, 145(2), 309-324.

Tanaka, N., Asaeda, T., Hasegawa, A., and Tanimoto, K. (2004). Modelling of the long-term competition between Typha angustifolia and Typha latifolia in shallow water - effects of eutrophication, latitude and initial advantage of belowground organs. Aquatic Botany, $79,295-310$.

Tanner, C.C. (1996). Plants for constructed wetland treatment systems - A comparison of the growth and nutrient uptake of eight emergent species. Ecological Engineering, 7, 59-83.

Templer, P., Findlay, S., and Wigand, C. (1998). Sediment chemistry associated with native and non-native macrophytes of a Hudson River marsh ecosystem. Wetlands, 18(1), 70-78.

Thompson, K., Miller, M.C., and Culley, T.M. (2007). Comparison of plant species richness, diversity, and biomass in Ohio wetlands. Ohio Journal of Science, 107(3), 32-38.

Thullen, J.S., Sartoris, J.J., and Nelson, S.M. (2005). Managing vegetation in surface-flow wastewater-treatment wetlands for optimal treatment performance. Ecological Engineering, 25, 583-593. 
Tiner, R.W. (1987). A Field Guide to Coastal Wetland Plants of the Northeastern United States. Amherst: The University of Massachusetts Press.

Troeh, F.R., and Thompson, L.M. (1993). Soils and Soil Fertility. New York: Oxford University Press.

United States Environmental Protection Agency (US EPA). (1986). Quality Criteria for Water. Washington, D.C: Author.

Wang, L., Lyons, J., Kanehl, P., Bannerman, R., and Emmons, E. (2000). Watershed urbanization and changes in fish communities in southeastern Wisconsin streams. Journal of the American Water Resources Association, 36, 1173-1189.

Wei, A., and Chow-Fraser, P. (2005). Untangling the confounding effects of urbanization and high water level on the cover of emergent vegetation in Cootes Paradise Marsh, a degraded coastal wetland of Lake Ontario. Hydrobiologia, 544, 1-9.

Weisner, S.E.B. (1993). Long-term competitive displacement of Typha latifolia by Typha angustifolia in a eutrophic lake. Oecologia, 94, 451-456.

Wetzel, P.R., and Kitchens, W.M. (2007). Vegetation change from chronic stress events: Detection of the effects of tide gate removal and long-term drought on a tidal marsh. Journal of Vegetation Science, 18, 431-442.

Wetzel, P.R., Kitchens, W.M., Brush, J.M, and Dusek, M.L. (2004). Use of reciprocal transplant study to measure the rate of plant community change in a tidal marsh along a salinity gradient. Wetlands, 24(4), 879-890.

Wetzel, P.R., and van der Valk, A.G. (1998). Effects of nutrient and soil moisture on competition between Carex stricta, Phalaris arundinacea, and Typha latifolia. Plant Ecology, 138, 179-190.

Whigham, D., Pittek, M., Hofmockel, K.H., Jordan, T., and Pepin, A.L. (2002). Biomass and nutrient dynamics in restored wetlands on the outer coastal plain of Maryland, USA. Wetlands, 22(3), 562-574.

Wong, T.H.F., Breen, P.F., Somes, N.L.G., and Lloys, S.D. (1999). Managing Urban Stormwater Using Constructed Wetlands. Victoria, Australia: Cooperative Research Centre for Catchment Hydrology.

Woo, I., and Zedler, J.B. (2002). Can nutrients alone shift a sedge meadow towards dominance by the invasive Typha $\times$ glauca? Wetlands, 22: 509-521.

Wood, A. (1995). Constructed wetlands in water pollution control: fundamentals to their understanding. Water Science Technology, 32(3): 21-29. 
Zar, J.H. (1999). Biostatistical Analysis (4 ${ }^{\text {th }}$ ed.). New Jersey: Prentice Hall.

Zedler, J.B., and Kercher, S. (2004). Causes and Consequences of Invasive Plants in Wetlands: Opportunities, Opportunists, and Outcomes. Critical Reviews in Plant Sciences, 23(5), $431-452$

Zhu, T., and Sikora, F.J. (1995). Ammonium and nitrate removal in vegetated and unvegetated gravel bed microcosm wetlands. Water Science and Technology, 32(3), 219-228. 